\title{
A Merry Dance Across the $\pi$-Cloud: Tracking the Transformation of a 2,7-Substituted Dihydropyrene Through a Thermally Stimulated Single-Crystal-to-Single-Crystal Reaction
}

Max Roemer*, Angus A. Gillespie, Gemma F. Turner, Gavin R. Flematti, Claire Hobday, Alexandre N. Sobolev, Duncan A. Wild, Gareth L. Nealon, Matthew J. Piggott, Stephen A. Moggach*, and George A. Koutsantonis*

Correspondence to:

*max.roemer@sydney.edu.au

*stephen.moggach@uwa.edu.au

*george.koutsantonis@uwa.edu.au

1. Thermally Induced Single-Crystal-to-Single-Crystal Transformation ....................................... 2

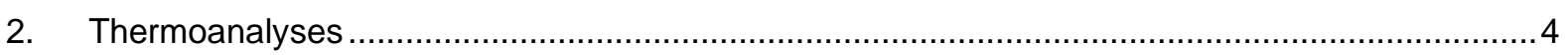

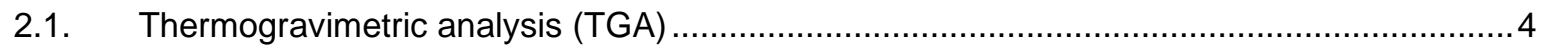

2.2. Differential Scanning Calometry (DSC) …............................................................. 5

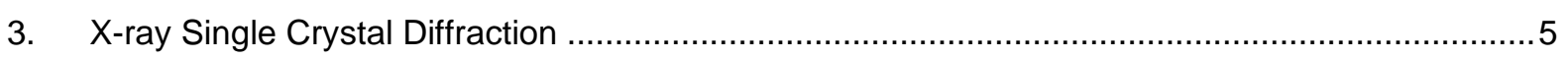

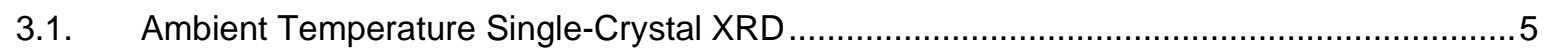

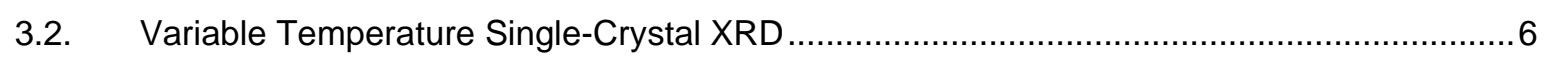

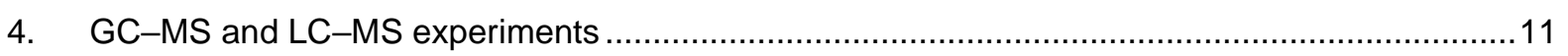

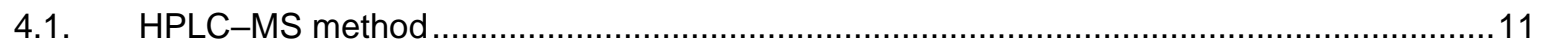

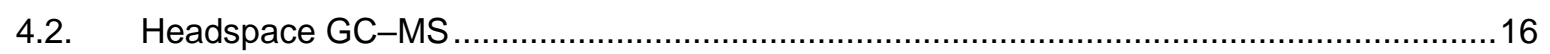

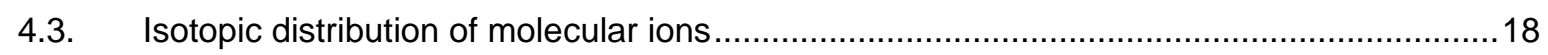

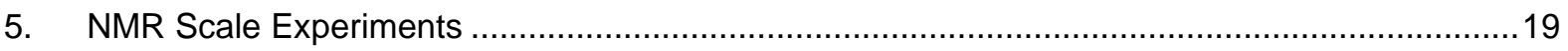

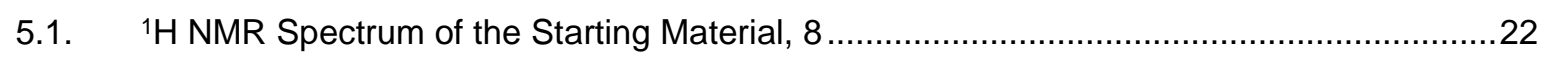

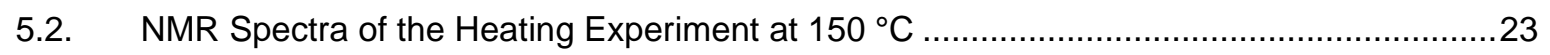

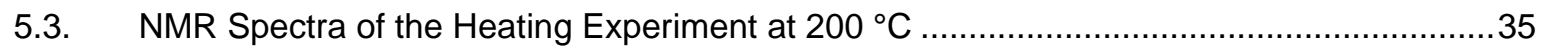

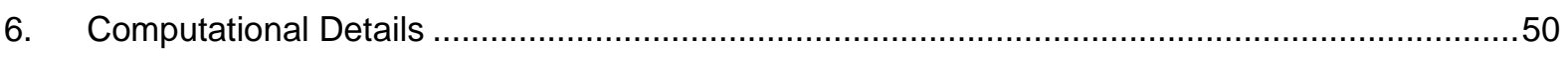

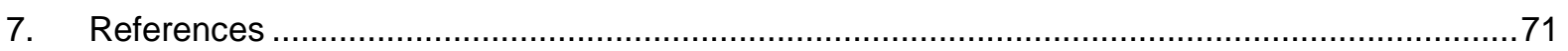




\section{Thermally Induced Single-Crystal-to-Single-Crystal Transformation}

Synthesis. 2,7-Bis((triisopropylsilyl)ethynyl)-10b,10c-diethyldihydropyrene (8) was synthesized in nine steps from dimethylisophthalate, in an overall yield of $~ 3 \%$, as described elsewhere. ${ }^{1}$ Single crystals of 8 were obtained by slow solvent evaporation from a solution of 8 in pentane at room temperature.

The transformation was first observed through a color change, while heating crystalline samples of DHP 8 on a Reichert melting point microscope. Several crystals were placed onto a glass slide and heated gradually from room temperature to 185 ${ }^{\circ} \mathrm{C}$. Progressive decolorization of the deep purple crystals started to occur at approximately $170{ }^{\circ} \mathrm{C}$ while the crystals remained intact. We captured the process by recording a video through the ocular of the melting point microscope for different samples with varying heating conditions. Figure S1 shows a crystalline sample heated from rt to approximately $140^{\circ} \mathrm{C}$, which was kept at this temperature for $20 \mathrm{~min}$.
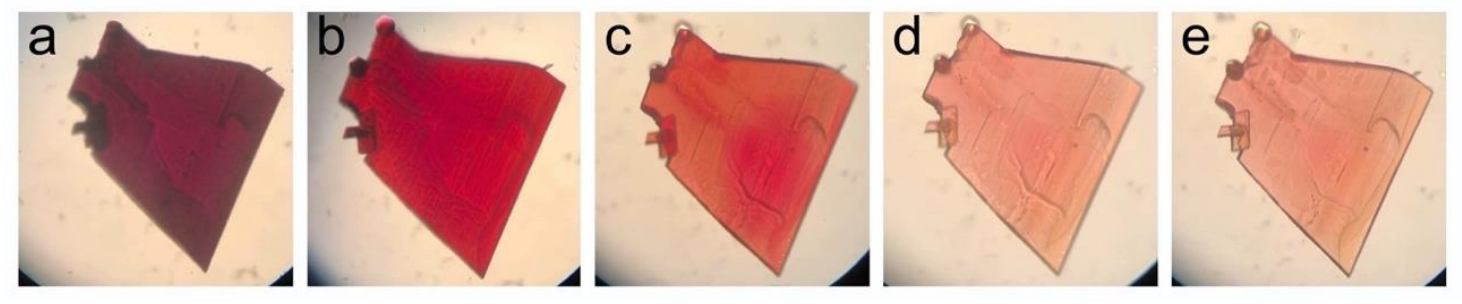

Figure S1. Transformation of a crystal of DHP 8. The images a-e are captured stills (cropped) from a recorded video. Over time the crystal decolorizes.

Figure S2 shows a sample, which was heated in a capillary. The sample was heated to $130^{\circ} \mathrm{C}$ over the course of $1 \mathrm{~h}$. 

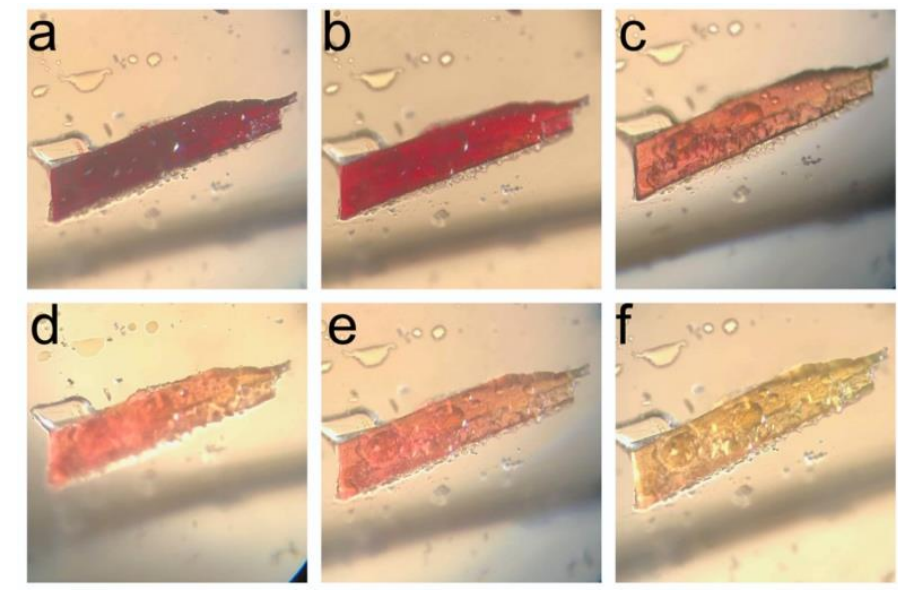

Figure S2. Cropped images of decolorization of a crystal of DHP 8. The crystal was photographed through the ocular of a melting point microscope at different time points.

A crystalline sample of 8 was heated to $130{ }^{\circ} \mathrm{C} \pm 2{ }^{\circ} \mathrm{C}$ on a calibrated hotplate. A gradual color change from dark red to yellow was observed over $1 \mathrm{~h}$. Since the crystallographic data indicates the occurrence two phase transitions at $87-97^{\circ} \mathrm{C}$ and $117-127^{\circ} \mathrm{C}$, the heating experiment was repeated on a separate crystal of 8 , in two stages of different temperatures. The crystal was first heated to $110^{\circ} \mathrm{C}$, slightly above the temperature at which the first phase transition occurs. A color change from dark red to light red occurred over approximately $2 \mathrm{~h}$, after which no further color change was observed upon heating at $110^{\circ} \mathrm{C}$ for an additional $1 \mathrm{~h}$. The temperature was then increased to $130^{\circ} \mathrm{C}$, and a color change from light red to yellow proceeded over 30 $\min$. No further color change was recorded after heating the crystal at $130^{\circ} \mathrm{C}$ for a further $2 \mathrm{~h}$ (Figure S3). 


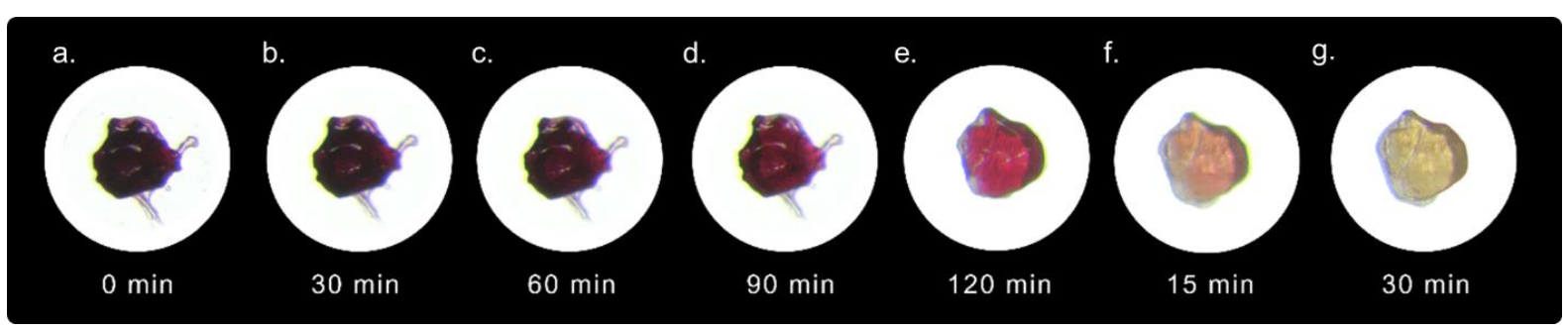

Figure S3. a-e. Gradual thermochromism in a single crystal of 8 upon heating to 110 ${ }^{\circ} \mathrm{C}$ for $2 \mathrm{~h}$. f-g. Continued, gradual transformation of 8 upon heating to $130^{\circ} \mathrm{C}$ for 30 $\min$.

\section{Thermoanalyses}

\subsection{Thermogravimetric analysis (TGA)}

TGA measurements were performed on a TA Instruments Discovery thermogravimetric analyzer. A platinum sample pan was flame treated, allowed to cool down to room temperature and tared on the thermogravimetric analyzer. DHP 8 (1 $\mathrm{mg}$ ) was added to the pan. The heating rate was set to $2{ }^{\circ} \mathrm{C} / \mathrm{min}$ and the temperature was gradually ramped up from $25^{\circ} \mathrm{C}$ to $250^{\circ} \mathrm{C}$. The weight loss was recorded over the course of the experiment.

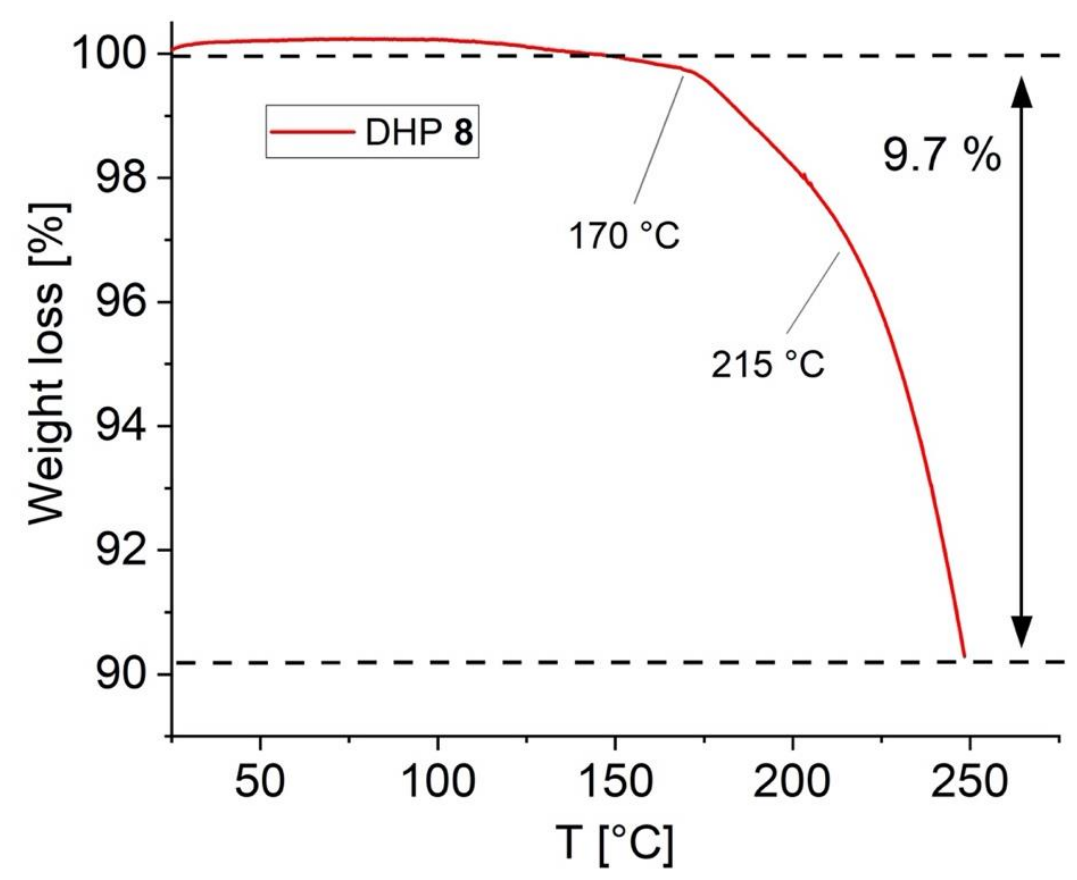

Figure S4. TGA curve of DHP 8. 


\subsection{Differential Scanning Calometry (DSC)}

DSC measurements were performed on a Mettler Toledo differential scanning calorimeter 823e. DHP 8 (1.6 mg) was weighed into an aluminum pan, which was sealed with a punctured aluminum cap and placed onto the DSC sensor of the differential scanning calorimeter, followed by an empty aluminum reference pan with aluminum cap. The sample was heated at a rate of $10^{\circ} \mathrm{C} / \mathrm{min}$ from $25^{\circ} \mathrm{C}$ to $250^{\circ} \mathrm{C}$ and the heat flow was monitored over the course of the heat induced transformation. The temperature was kept for $5 \mathrm{~min}$ at $250^{\circ} \mathrm{C}$ and slowly cooled down to $25^{\circ} \mathrm{C}$ with a cooling rate of $10^{\circ} \mathrm{C} / \mathrm{min}$. The experiment was repeated with another sample of 8 . A second run on one of the samples showed unambiguously that irreversible decomposition occurred, as the experimental curve is essentially featureless.

\section{X-ray Single Crystal Diffraction}

\subsection{Ambient Temperature Single-Crystal XRD}

A clear light red block-shaped crystal of 2,7-bis((triisopropylsilyl)ethynyl)-10b,10c diethyldihydropyrene (8) with dimensions $0.21 \times 0.12 \times 0.08 \mathrm{~mm}^{3}$ was mounted, and data collected using a XtaLAB Synergy, Single source at home/near, HyPix diffractometer operating at $T=300.00(10) \mathrm{K}$.

Data were measured using $\omega$ scans using $\mathrm{Cu} \mathrm{K}_{\alpha}$ radiation. The diffraction pattern was indexed and the total number of runs and images was based on the strategy calculation from the program CrysAlisPro ${ }^{2}$. The maximum resolution that was achieved was $\Theta=75.463^{\circ}(0.80 \AA)$. The diffraction pattern was indexed and the total number of runs and images was based on the strategy calculation from the program CrysAlisPro ${ }^{2}$. The unit cell was refined using CrysAlisPro ${ }^{2}$ on 11707 reflections, $20 \%$ of the observed reflections. Data reduction, scaling and absorption corrections were 
performed using CrysAlisPro. ${ }^{2}$ The final completeness is $99.90 \%$ out to $75.463^{\circ}$ in $\Theta$. A gaussian absorption correction was performed using CrysAlisPro. ${ }^{2}$ Numerical absorption correction based on gaussian integration over a multifaceted crystal model Empirical absorption correction using spherical harmonics, implemented in SCALE3 ABSPACK scaling algorithm.. The absorption coefficient $\mu$ of this material is $0.980 \mathrm{~mm}^{-1}$ at this wavelength $(\lambda=1.54184 \AA)$ and the minimum and maximum transmissions are 0.730 and 1.000.

The structure was solved and the space group $P-1$ (\# 2) determined by the XT structure solution program ${ }^{3}$ using dual methods and refined by full matrix least squares minimization on $F^{2}$ using version $2018 / 3$ of $\mathrm{XL}$ (Sheldrick, 2008). All non-hydrogen atoms were refined anisotropically. Hydrogen atom positions were calculated geometrically and refined using the riding model. There are two 0.5 molecules, and one full molecule in the asymmetric unit, which is represented by the reported sum formula. In other words: $Z$ is 4 , and $Z^{\prime}$ is 2 .

\subsection{Variable Temperature Single-Crystal XRD}

The same crystal as used in the ambient temperature experiment, was heated from 300 to $400 \mathrm{~K}$ in approximately $10 \mathrm{~K}$ steps. Data were measured using $\omega$ scans using $\mathrm{Cu} \mathrm{K}_{\alpha}$ radiation. On increasing temperature, the crystal was allowed to equilibrate for 10 minutes prior to data collection (Table S1).

From 300-370 K, and 390-400 K, only unit cell dimensions were obtained. Data reduction on these data were performed using CrysAlisPro (V1.171.41.103a). ${ }^{2}$ On increasing temperature, two phase transitions were observed. The first occurred on increasing temperature from $360-370 \mathrm{~K}$, the second on increasing temperature from 
390-400 K. The ambient temperature, and the two subsequent phases are referred to as phase-I, II and III, respectively.

At $380 \mathrm{~K}$, and on undergoing the transition from phase-I to II, data were measured using $\omega$ scans using $\mathrm{Cu} \mathrm{K}_{\alpha}$ radiation. The diffraction pattern was indexed and the total number of runs and images was based on the strategy calculation from the program CrysAlisPro. ${ }^{2}$ The maximum resolution that was achieved was $\Theta=44.416^{\circ}(1.10 \AA)$. The diffraction pattern was indexed and the total number of runs and images was based on the strategy calculation from the program CrysAlisPro (V1.171.41.103a). ${ }^{2}$ The unit cell was refined using CrysAlisPro (V1.171.41.103a) $)^{2}$ on 2978 reflections, $18 \%$ of the observed reflections.

Data reduction, scaling and absorption corrections were performed using CrysAlisPro $(\mathrm{V} 1.171 .41 .103 \mathrm{a})^{2}$. The final completeness is $99.50 \%$ out to $44.416^{\circ}$ in $\Theta$. A Gaussian absorption correction was performed using CrysAlisPro ${ }^{2}$ over a multifaceted crystal model, implemented in SCALE3 ABSPACK scaling algorithm. The absorption coefficient $\mu$ of this material is $0.944 \mathrm{~mm}^{-1}$ at this wavelength $(\lambda=1.54184 \AA)$ and the minimum and maximum transmissions are 0.624 and 1.000 .

The structure was solved and the space group $P-1$ (\# 2) determined by the XT structure solution program ${ }^{4}$ using dual methods and refined by full matrix least squares minimization on $F^{2}$ using $\mathrm{XL}$ (Sheldrick, 2008). ${ }^{5}$ All non-hydrogen atoms were refined anisotropically. Hydrogen atom positions were calculated geometrically and refined using the riding model. Hydrogen atom positions were calculated geometrically and refined using the riding model.

There are two 0.5 molecules in the asymmetric unit, which is represented by the reported sum formula. In other words: $Z$ is 2 and $Z^{\prime}$ is 1 . 
Table S1. Unit cell dimensions as a function of increasing temperature for 2,7bis((triisopropylsilyl)ethynyl)-10b,10c diethyldihydropyrene.

\begin{tabular}{|c|c|c|c|c|c|c|c|c|}
\hline$T(K)$ & a-axis $(\AA)$ & b-axis $(\AA)$ & c-axis $(\AA)$ & $\alpha\left(^{\circ}\right)$ & $\beta\left(^{\circ}\right)$ & $\gamma\left({ }^{\circ}\right)$ & $V\left(\AA^{3}\right)$ & Phase \\
\hline 300 & $15.3303(4)$ & $15.4568(4)$ & $18.0962(7)$ & $105.180(3)$ & $100.474(3)$ & $98.506(2)$ & $3982.2(2)$ & I \\
\hline 310 & $15.346(4)$ & $15.466(4)$ & $18.094(6)$ & $105.08(3)$ & $100.45(2)$ & $98.54(2)$ & $3990(2)$ & I \\
\hline 320 & $15.379(4)$ & $15.472(5)$ & $18.098(5)$ & $105.01(3)$ & $100.51(2)$ & $98.53(2)$ & 4002(2) & I \\
\hline 330 & $15.389(4)$ & $15.493(5)$ & $18.123(6)$ & $105.05(3)$ & $100.49(2)$ & 98.54(2) & 4015(2) & I \\
\hline 360 & $15.489(7)$ & $15.509(5)$ & $18.208(7)$ & $104.85(3)$ & $100.50(3)$ & $99.03(3)$ & 4061(3) & I \\
\hline 370 & $7.727(5)$ & $15.520(15)$ & $18.204(6)$ & $100.28(5)$ & $104.93(4)$ & $99.21(7)$ & 2026(3) & II \\
\hline 380 & $7.6512(8)$ & $15.6155(7)$ & $18.2696(10)$ & $105.199(4)$ & $91.877(6)$ & $100.182(6)$ & 2066.1(3) & II \\
\hline 390 & $7.633(8)$ & $15.671(17)$ & $18.350(13)$ & $105.28(7)$ & $91.82(8)$ & $100.46(10)$ & $2075(3)$ & II \\
\hline 400 & 7.787(3) & $7.822(4)$ & $18.435(7)$ & $83.97(4)$ & 95.32(3) & $105.72(4)$ & $1072.5(9)$ & III \\
\hline $300^{*}$ & $7.7585(19)$ & $7.8244(19)$ & $18.466(4)$ & $83.11(2)$ & $97.19(2)$ & $105.08(2)$ & $1069.4(4)$ & III \\
\hline $100^{*}$ & $7.5043(12)$ & $7.9062(11)$ & $17.683(2)$ & $90.767(11)$ & $101.248(13)$ & $106.611(13)$ & $983.4(3)$ & III \\
\hline
\end{tabular}

*Indicates data were collected on decreasing temperature.

On undergoing the transition from phase-II to III, a noticeable reduction in the quality of the diffraction pattern was observed. To get better data, the same crystal was then cooled to $300 \mathrm{~K}$, and then further to $100 \mathrm{~K}$ after the transition.

At $100 \mathrm{~K}$, data were measured using $\omega$ scans using $\mathrm{Cu} \mathrm{K}_{\alpha}$ radiation. The diffraction pattern was indexed and the total number of runs and images was based on the strategy calculation from the program CrysAlisPro. ${ }^{6}$ The maximum resolution that was achieved was $\Theta=77.550^{\circ}(0.79 \AA)$.

The diffraction pattern was indexed and the total number of runs and images was based on the strategy calculation from the program CrysAlisPro (V1.171.40.53). ${ }^{6}$ The unit cell was refined using CrysAlisPro $(\mathrm{V} 1.171 .40 .53)^{6}$ on 2590 reflections, $20 \%$ of the observed reflections.

Data reduction, scaling and absorption corrections were performed using CrysAlisPro (V1.171.40.53). ${ }^{6}$ The final completeness is $98.10 \%$ out to $77.550^{\circ}$ in $\Theta$. A multi-scan absorption correction was performed using CrysAlisPro $(\mathrm{V} 1.171 .40 .53)^{6}$ using spherical harmonics, implemented in SCALE3 ABSPACK scaling algorithm. The 
absorption coefficient $\mu$ of this material is $0.955 \mathrm{~mm}^{-1}$ at this wavelength $(\lambda=1.54184$ $\AA$ ) and the minimum and maximum transmissions are 0.435 and 1.000 .

The structure was solved and the space group $P-1$ (\#2) determined by the olex2.solve 1.3 structure solution program ${ }^{7}$ using iterative methods and refined by full matrix least squares minimization on $F^{2}$ using $\mathrm{XL}$ (Sheldrick). ${ }^{5}$ All non-hydrogen atoms were refined anisotropically. Hydrogen atom positions were calculated geometrically and refined using the riding model.

The value of $Z^{\prime}$ is 0.5 . This means that only half of the formula unit is present in the asymmetric unit, with the other half consisting of symmetry equivalent atoms.

Crystallographic tables for phase-I, II and III collected at $300 \mathrm{~K}, 380 \mathrm{~K}$ and $100 \mathrm{~K}$ respectively, is given below (Table S2).

All crystallographic data have been deposited with the CCDC (CCDC 20808842080886) and can be obtained free of charge via https://www.ccdc.cam.ac.uk/structures/, or from the Cambridge Crystallographic Data Centre. 
Table S2. Summary of the crystallographic data for phase-I, II and III for 2,7bis((triisopropylsilyl)ethynyl)-10b,10c diethyldihydropyrene (8) (phases-I and II) and 2,7-bis((triisopropylsilyl)ethynyl)-pyrene (12) (phase-III). For all structures: triclinic, $P$ 1. Experiments were carried out with $\mathrm{Cu} K$ Ka radiation using a XtaLAB Synergy, Single source at home/near, HyPix. $\mathrm{H}$-atom parameters were constrained.

\begin{tabular}{|c|c|c|c|}
\hline Phase & Phase I & Phase II & Phase III \\
\hline CCDC No. & 2080884 & 2080885 & 2080884 \\
\hline Chemical formula & $\mathrm{C}_{42} \mathrm{H}_{60} \mathrm{Si}_{2}$ & $2\left(\mathrm{C}_{21} \mathrm{H}_{31} \mathrm{Si}\right)$ & $\mathrm{C}_{38} \mathrm{H}_{50} \mathrm{Si}_{2}$ \\
\hline & 621.08 & 623.09 & 562.96 \\
\hline Temperature (K) & 300 & 380 & 100 \\
\hline$a, b, c(\AA)$ & $\begin{array}{l}15.3303(4), \\
15.4568(4), \\
18.0962(7)\end{array}$ & $\begin{array}{l}7.6512(8), \\
15.6155(7), \\
18.2696(10)\end{array}$ & $\begin{array}{l}7.5043(12), \\
7.9062(11), \\
17.683(2)\end{array}$ \\
\hline$\alpha, \beta, \gamma\left(^{\circ}\right)$ & $\begin{array}{l}105.180(3), \\
100.474(3), \\
98.506(2)\end{array}$ & $\begin{array}{l}105.199(4), \\
91.877(7), \\
100.182(6)\end{array}$ & $\begin{array}{l}90.767(11), \\
101.248(13), \\
106.611(13)\end{array}$ \\
\hline$V\left(\AA^{3}\right)$ & $3982.2(2)$ & $2066.1(3)$ & $983.4(3)$ \\
\hline Z & 4 & 2 & 1 \\
\hline$\mu\left(\mathrm{mm}^{-1}\right)$ & 0.98 & 0.94 & 0.96 \\
\hline $\begin{array}{l}\text { Crystal size }(\mathrm{mm}) \\
\text { Data collection }\end{array}$ & $0.21 \times 0.12 \times 0.08$ & $0.21 \times 0.12 \times 0.08$ & $0.21 \times 0.12 \times 0.08$ \\
\hline Absorption correction & $\begin{array}{l}\text { Gaussian } \\
\text { CrysAlis PRO } \\
1.171 .41 .103 \mathrm{a}^{2} \\
\text { Numerical absorption } \\
\text { correction based on } \\
\text { gaussian integration } \\
\text { over a multifaceted } \\
\text { crystal model } \\
\text { Empirical absorption } \\
\text { correction using } \\
\text { spherical harmonics, } \\
\text { implemented in } \\
\text { SCALE3 ABSPACK } \\
\text { scaling algorithm. }\end{array}$ & $\begin{array}{l}\text { Gaussian } \\
\text { CrysAlis } P R O \\
1.171 .41 .103 \mathrm{a}^{2} \\
\text { Numerical absorption } \\
\text { correction based on } \\
\text { gaussian integration } \\
\text { over a multifaceted } \\
\text { crystal model } \\
\text { Empirical absorption } \\
\text { correction using } \\
\text { spherical harmonics, } \\
\text { implemented in } \\
\text { SCALE3 ABSPACK } \\
\text { scaling algorithm. }\end{array}$ & $\begin{array}{l}\text { Multi-scan } \\
\text { CrysAlis PRO } \\
1.171 .40 .53^{6} \\
\text { Empirical absorption } \\
\text { correction using } \\
\text { spherical harmonics, } \\
\text { implemented in } \\
\text { SCALE3 ABSPACK } \\
\text { scaling algorithm. }\end{array}$ \\
\hline$T_{\min }, T_{\max }$ & $0.730,1.000$ & $0.624,1.000$ & $0.435,1.000$ \\
\hline $\begin{array}{l}\text { No. of measured, } \\
\text { independent and } \\
\text { observed }[I>2 \sigma(I)] \\
\text { reflections }\end{array}$ & $59731,15896,11038$ & 16321, 3200, 1915 & $12949,3827,3050$ \\
\hline$R_{\text {int }}$ & 0.055 & 0.066 & 0.048 \\
\hline$\theta_{\max }\left({ }^{\circ}\right)$ & 75.5 & 44.4 & 77.6 \\
\hline $\begin{array}{l}(\sin \theta / \lambda)_{\max }\left(\AA^{-1}\right) \\
\text { Refinement }\end{array}$ & 0.628 & 0.454 & 0.633 \\
\hline$R\left[F^{2}>2 \sigma\left(F^{2}\right)\right], w R\left(F^{2}\right), S$ & $0.079,0.243,1.03$ & $0.139,0.414,1.57$ & $0.152,0.451,1.88$ \\
\hline No. of reflections & 15896 & 3200 & 3827 \\
\hline No. of parameters & 821 & 415 & 158 \\
\hline No. of restraints & 13 & 51 & 31 \\
\hline$\left.\Delta\rangle_{\max }, \Delta\right\rangle_{\min }\left(\mathrm{e} \AA^{-3}\right)$ & $0.59,-0.31$ & $0.53,-0.26$ & $0.84,-0.34$ \\
\hline
\end{tabular}




\section{GC-MS and LC-MS experiments}

Samples of DHP $8(0.2 \mathrm{mg}, 0.3 \mu \mathrm{mol})$ were heated at the temperatures and for the times specified by placing in an aluminum heating block specially fabricated for heating $2 \mathrm{~mL}$ vials. The heating block was heated with a standard hot plate with temperature control and contained a thermometer for accurate temperature measurement. After the heating, the formed solid products were dissolved in $1: 1(\mathrm{v}, \mathrm{v})$ acetone:acetonitrile (1 $\mathrm{mL}$ ) and analyzed by HPLC-MS. In separate experiments, the headspace of the vial containing the formed solids was analyzed by GCMS.

\subsection{HPLC-MS method}

HPLC-MS was conducted using a Waters Alliance e2695 HPLC connected to a Waters 2998 diode array detector and Waters LCT Premier XE time-of-flight mass spectrometer with an APCI source operating in positive ionization mode. For high resolution mass spectra, the time-of-flight mass spectrometer was calibrated using sodium formate solution $(0.05 \mathrm{M} \mathrm{NaOH}+0.5 \%$ formic acid in 9:1 (v/v) isopropanol/water) and the analyses were conducted using leucine enkephalin (200 $\mathrm{pg} \mu \mathrm{L}^{-1}$ ) as an internal lock mass. The corona current was set at $20 \mu \mathrm{A}$ with $100 \mathrm{~V}$ sample cone voltage. The source was operated at $80{ }^{\circ} \mathrm{C}$ with drying gas operated at $350{ }^{\circ} \mathrm{C}$. Drying gas $\left(\mathrm{N}_{2}\right)$ was set at $650 \mathrm{~L} / \mathrm{h}$ and the cone flow was set at $20 \mathrm{~L} / \mathrm{h}$. The mass spectrometer was set to record between 100 and 1200 amu, while the diode array detector collected UV absorbance data between 220 and $799 \mathrm{~nm}$.

For HPLC-MS separation, a Zorbax StableBond phenyl column $(250 \mathrm{~mm} \times 4.6 \mathrm{~mm}, 5$ $\mu \mathrm{m}$, Agilent technologies, USA) was used with a flow rate of $1 \mathrm{~mL} \mathrm{~min}^{-1}$, which passed through the diode array detector and was split 1:1 before entering the mass spectrometer. The mobile phase consisted of $80 \%$ acetonitrile/water $(+0.1 \%$ formic 
acid) that was held constant for $20 \mathrm{~min}$, and was then increased to $100 \%$ acetonitrile over $10 \mathrm{~min}$ and held for $5 \mathrm{~min}$. The injection volume was $20 \mu \mathrm{L}$.

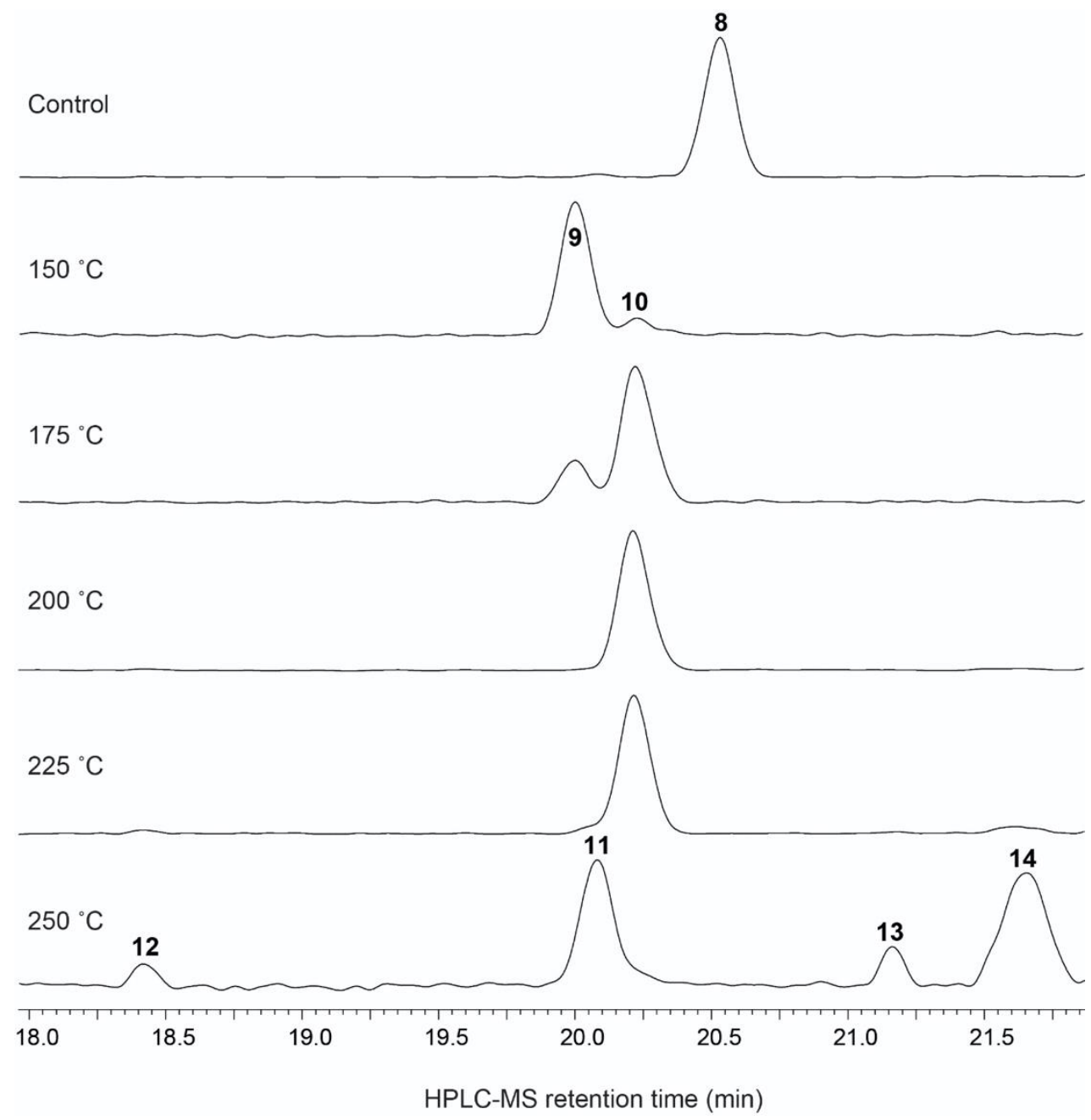

Figure S5. HPLC-MS base peak chromatograms (BPC) of the different reactions obtained by heating $8(0.2 \mathrm{mg})$ for 5 mins at the specified temperatures. Compound assignments are indicated in bold type above the corresponding peak. 

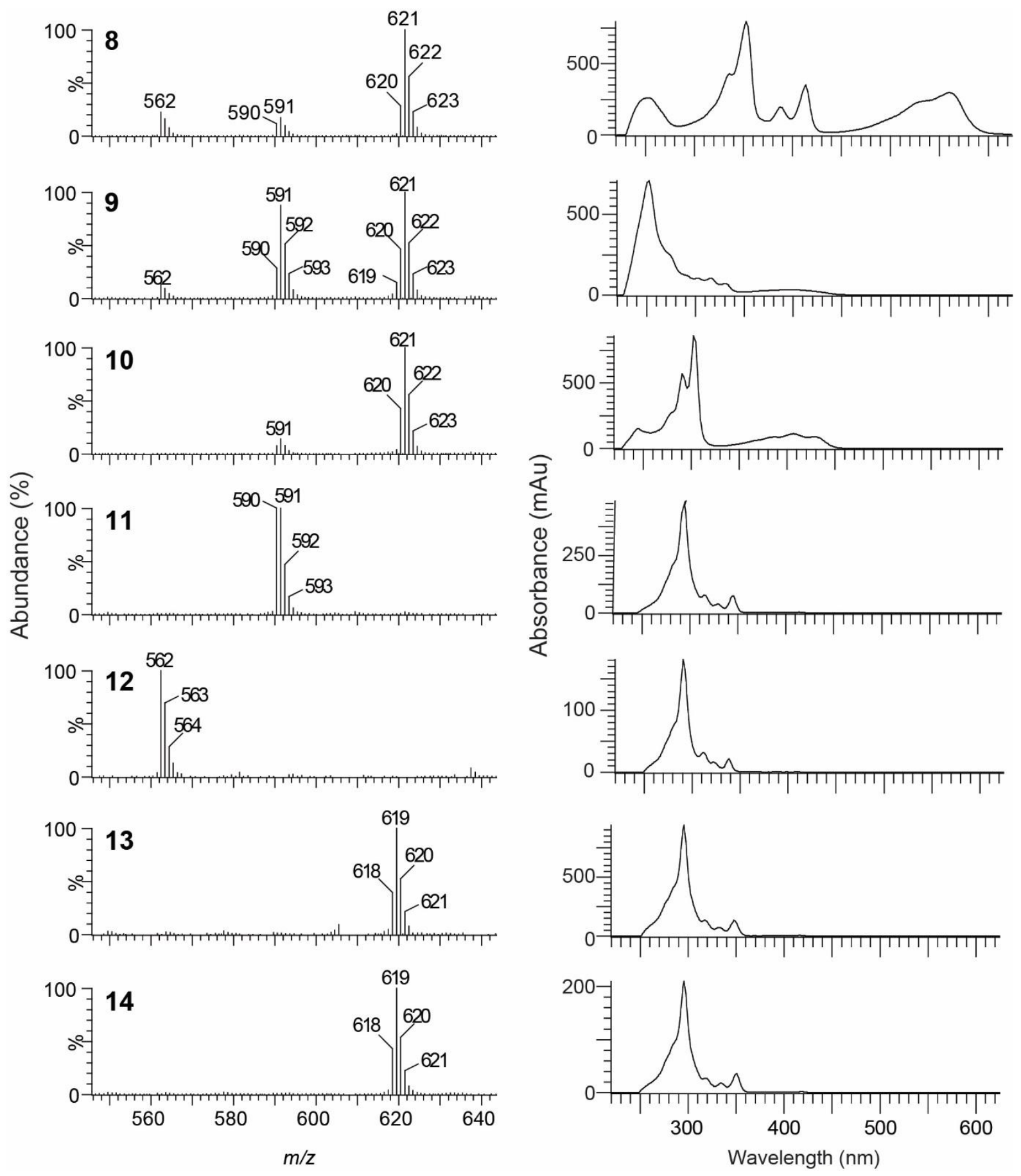

Figure S6. APCI mass spectra and UV absorbance obtained for each compound using HPLC-DAD-MS. 
Table S3. Accurate mass measurements and calculated molecular formulas for each compound.

\begin{tabular}{cccc}
\hline Compound & Experimental mass & Calculated mass & Molecular formula [M+H] \\
\hline $\mathbf{8}$ & 621.4321 & 621.4312 & $\mathrm{C}_{42} \mathrm{H}_{61} \mathrm{Si}_{2}$ \\
$\mathbf{9}$ & 621.4318 & 621.4312 & $\mathrm{C}_{42} \mathrm{H}_{61} \mathrm{Si}_{2}$ \\
$\mathbf{1 0}$ & 621.4301 & 621.4312 & $\mathrm{C}_{42} \mathrm{H}_{61} \mathrm{Si}_{2}$ \\
$\mathbf{1 1}$ & 591.3837 & 591.3842 & $\mathrm{C}_{40} \mathrm{H}_{55} \mathrm{Si}_{2}$ \\
$\mathbf{1 2}$ & 563.3508 & 563.3529 & $\mathrm{C}_{38} \mathrm{H}_{51} \mathrm{Si}_{2}$ \\
$\mathbf{1 3}$ & 619.4149 & 619.4155 & $\mathrm{C}_{42} \mathrm{H}_{59} \mathrm{Si}_{2}$ \\
$\mathbf{1 4}$ & 619.4166 & 619.4155 & $\mathrm{C}_{42} \mathrm{H}_{59} \mathrm{Si}_{2}$ \\
\hline
\end{tabular}

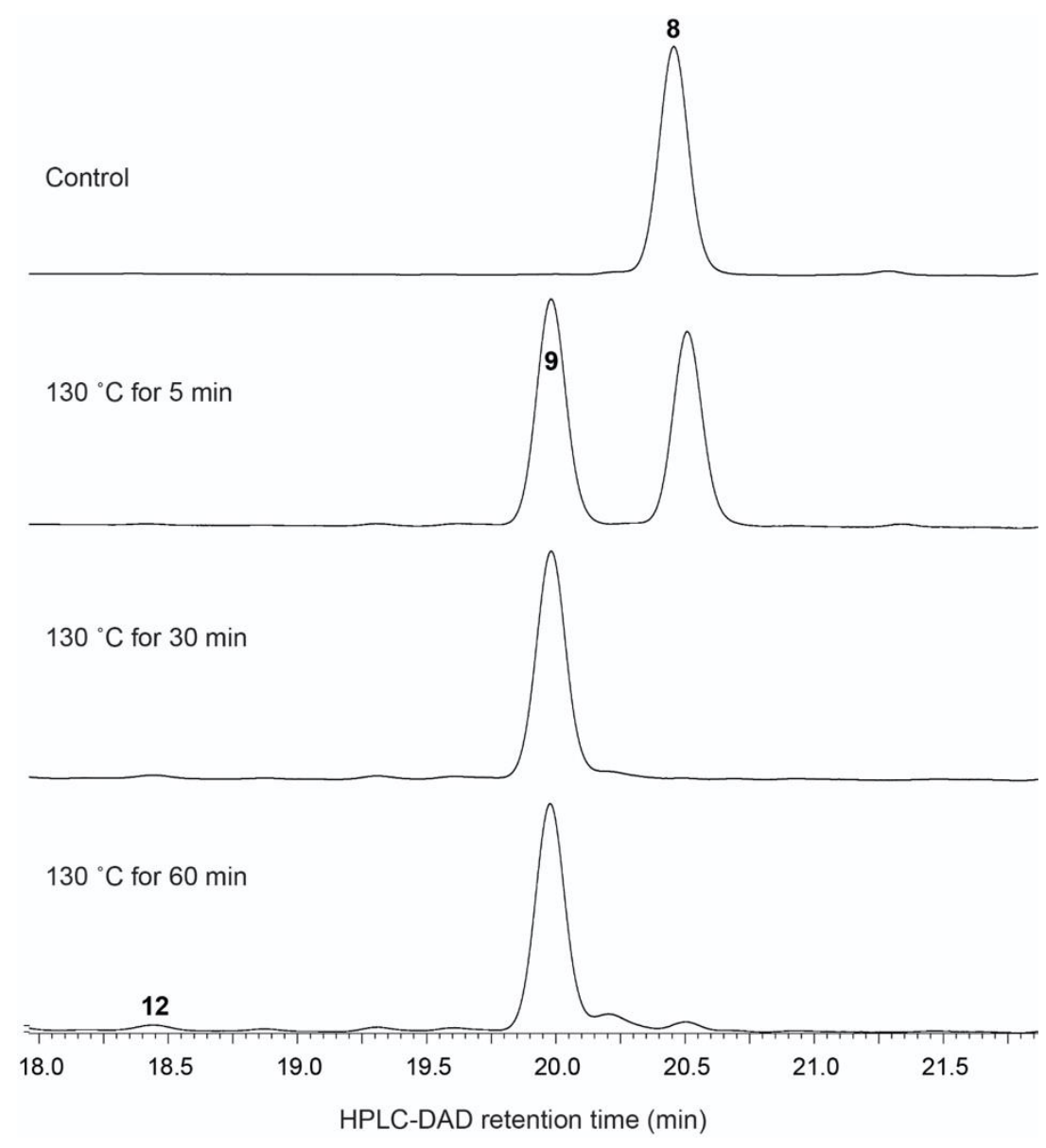

Figure S7. HPLC-diode array detector (DAD) chromatograms of the different reactions obtained by heating $8(0.2 \mathrm{mg})$ for different times at $130^{\circ} \mathrm{C}$. 


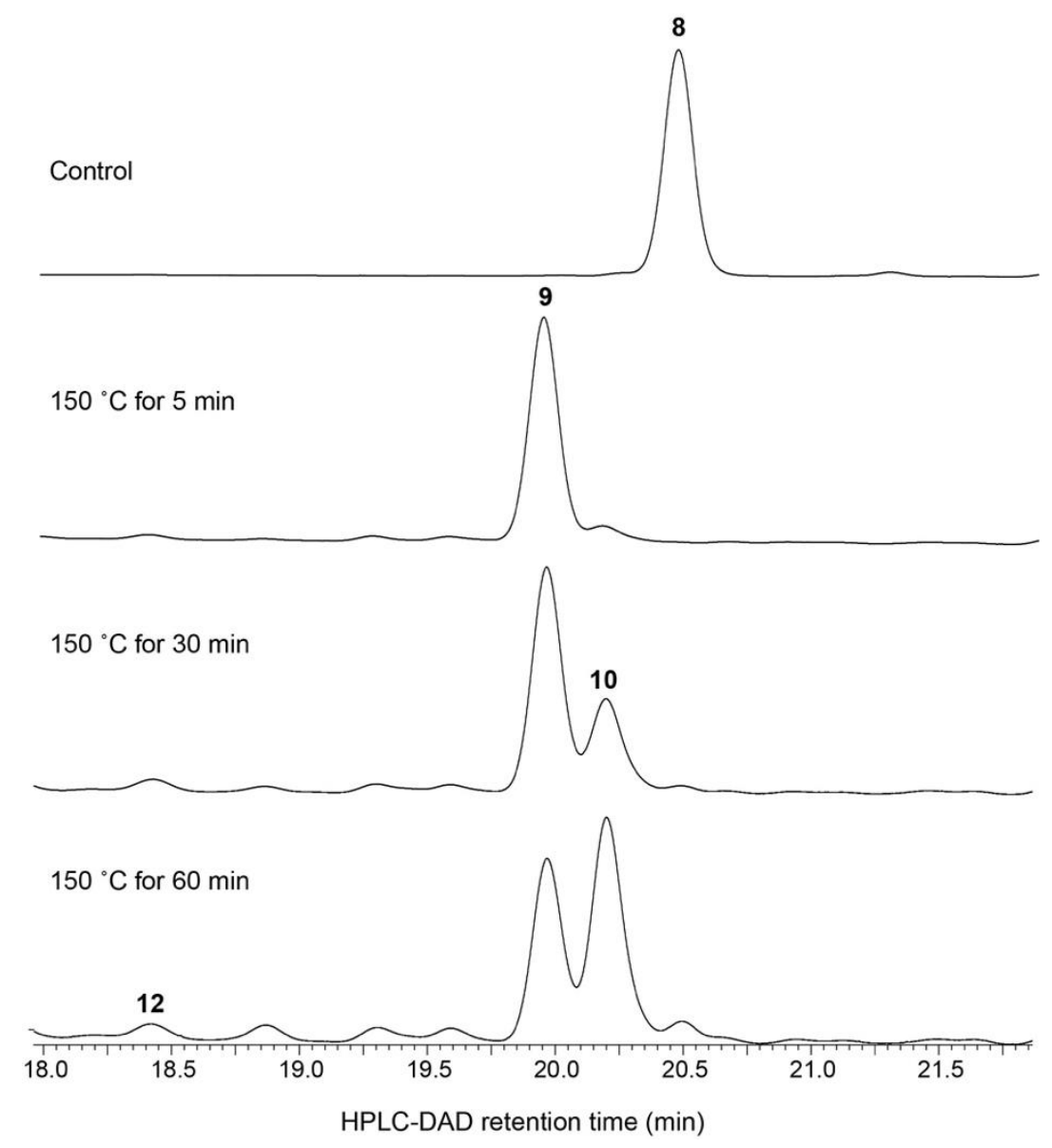

Figure S8. HPLC-diode array detector (DAD) chromatograms of the different reactions obtained by heating $8(0.2 \mathrm{mg})$ for different times at $150^{\circ} \mathrm{C}$. 


\subsection{Headspace GC-MS}

Headspace GC-MS was conducted using a Hewlett Packard 5890 GC connected to a Hewlett Packard 5972 mass spectrometer equipped with a Restek QPLOT GC column ( $30 \mathrm{~m} \times 0.32 \mathrm{~mm} \times 10 \mu \mathrm{m}$ film thickness, Restek, USA), using helium as a carrier gas with a constant flow rate of $1.0 \mathrm{~mL} / \mathrm{min}$. A scan range of $\mathrm{m} / \mathrm{z} 20-300$ and a solvent delay of 3 min were used. Injections were carried out using a gas tight syringe (250 $\mu \mathrm{L}$, SGE Analytical Science, Australia) with splitless injection of $50 \mu \mathrm{L}$ of the test sample. The ion source was set to $230{ }^{\circ} \mathrm{C}$, while the injector and transfer line temperatures were set to $250{ }^{\circ} \mathrm{C}$. The oven temperature started at $35{ }^{\circ} \mathrm{C}$, which was held for $5 \mathrm{~min}$, and then ramped at $10{ }^{\circ} \mathrm{C} / \mathrm{min}$ to $250{ }^{\circ} \mathrm{C}$, and held for $5 \mathrm{~min}$. $\mathrm{C}_{1}-\mathrm{C}_{6}$ hydrocarbon standards (15 ppm, Scotty Analyzed Gases, Scotty 4, p/n 501778, Supelco Bellefonte, USA) and $\mathrm{C}_{2}-\mathrm{C}_{6}$ alkene standards (100 ppm, Scotty Analyzed Gases, Scotty 14, p/n 332300-U, Supelco, Bellefonte, USA) were injected (ca. $1 \mathrm{sec}$ ) into a $2 \mathrm{~mL}$ vial and the headspace was analyzed as above using the same method. Oxygenated standards were analyzed by adding two drops of the standard (AR grade) to a vial and the headspace was sampled as above using the same method. 


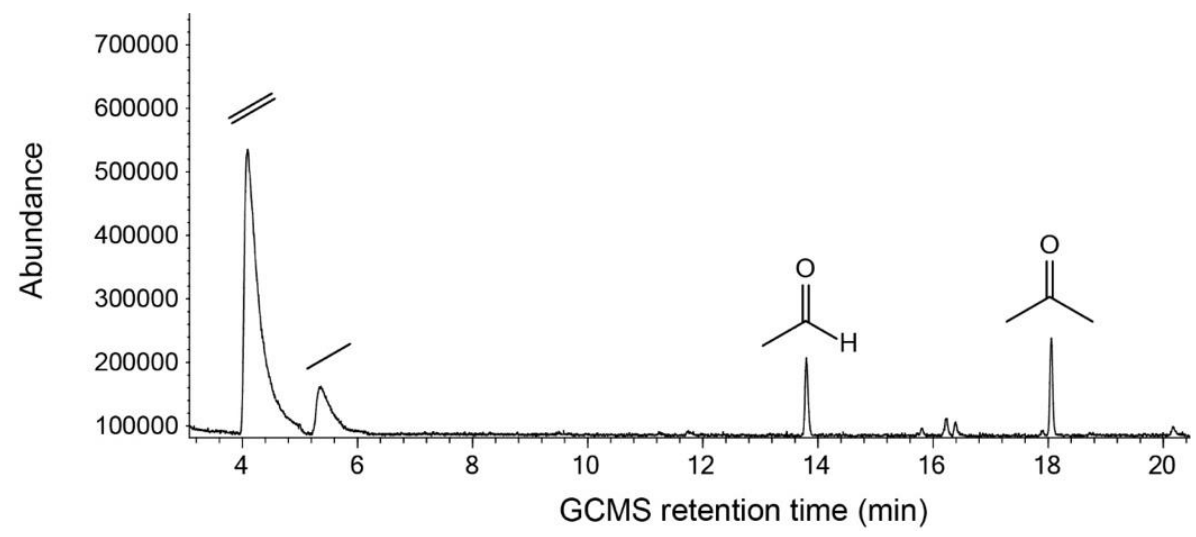

Figure S9. GC-MS total ion chromatogram of the volatiles detected in the headspace after heating $8(8 \mathrm{mg})$ at $150{ }^{\circ} \mathrm{C}$ for $5 \mathrm{~min}$.

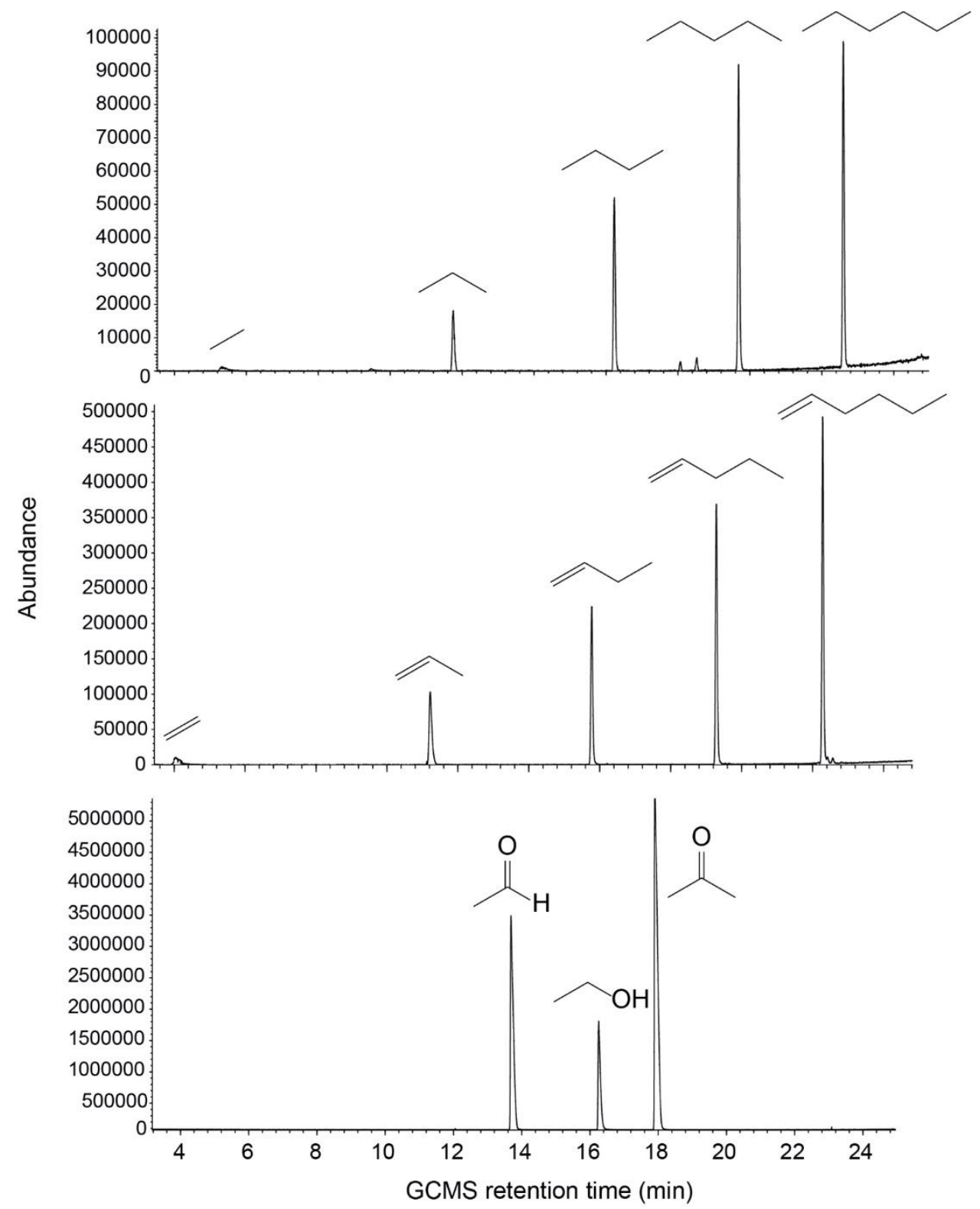

Figure S10. GC-MS total ion chromatogram of alkane, alkene and oxygenated standards. 


\subsection{Isotopic distribution of molecular ions}

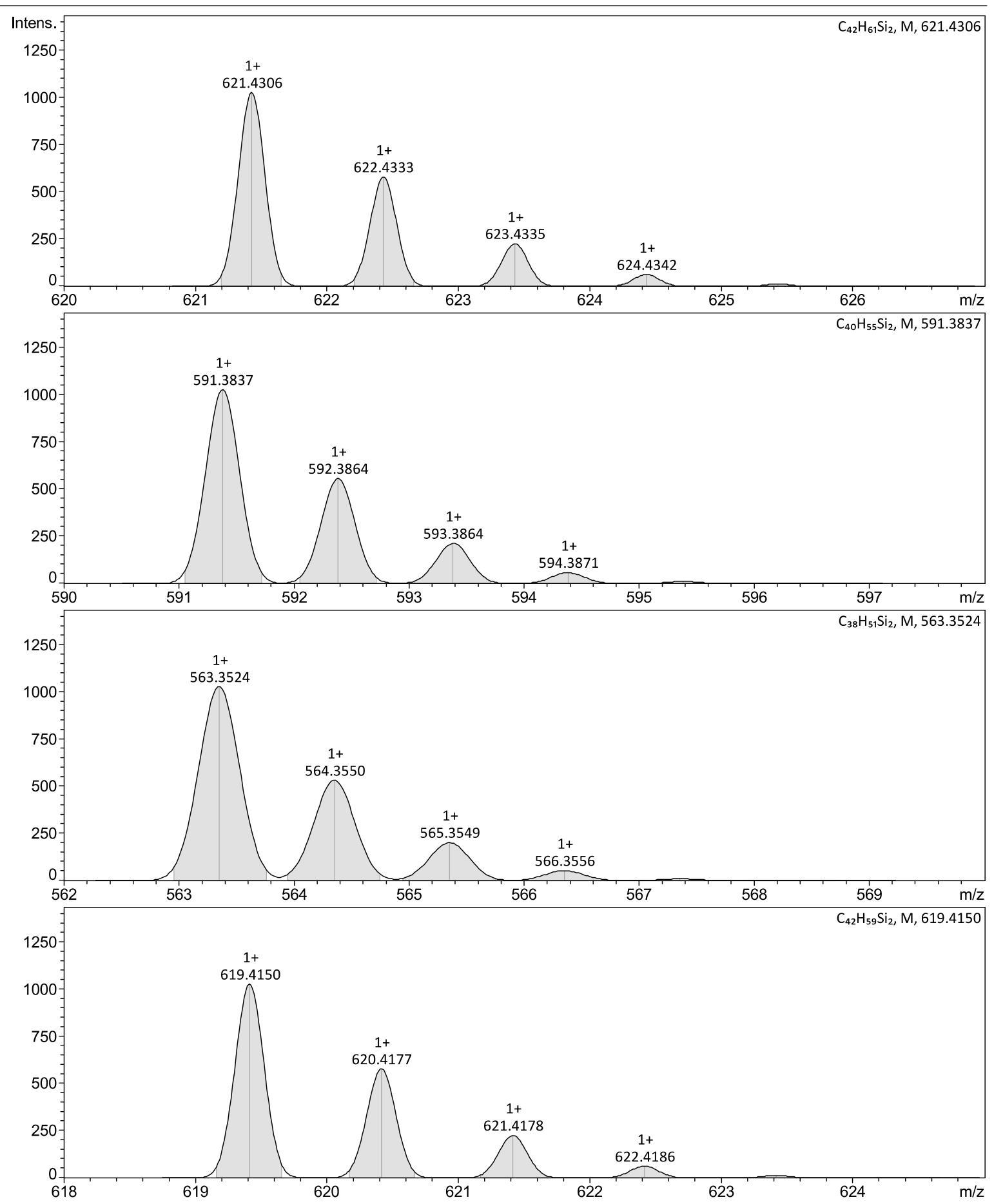

Figure S11. Isotopic distribution of the relevant molecular ions. 


\section{NMR Scale Experiments}

A sample of DHP $8(2.0 \mathrm{mg})$ was dissolved in pentane $(2 \mathrm{~mL})$. Aliquots of $200 \mu \mathrm{L}$ were dispensed into $\mathrm{GC}$ vials and the solvent was removed via a stream of $\mathrm{N}_{2}$ before taking the samples into a glovebox overnight and sealing under an argon atmosphere. The sealed samples were heated at the desired temperature $\left(150,200\right.$ and $\left.250{ }^{\circ} \mathrm{C}\right)$ for 5 min in an aluminum heating block. The samples, containing $0.2 \mathrm{mg}$ DHP 8 each, were then dissolved in chloroform- $d(50 \mu \mathrm{L})$ and analyzed by a suite of NMR experiments. These include 1D ${ }^{1} \mathrm{H},{ }^{13} \mathrm{C}$ and DEPT-135 experiments and 2D HMBC, HSQC and NOESY experiments, which were recorded on a Bruker AV-600 spectrometer, fitted with a microprobe. Selected ranges of the ${ }^{1} \mathrm{H}$ NMR spectra of the heating experiments are shown in Figure S12. The ${ }^{1} \mathrm{H}$ NMR spectrum of the starting material DHP 8 is shown in Figure S13.

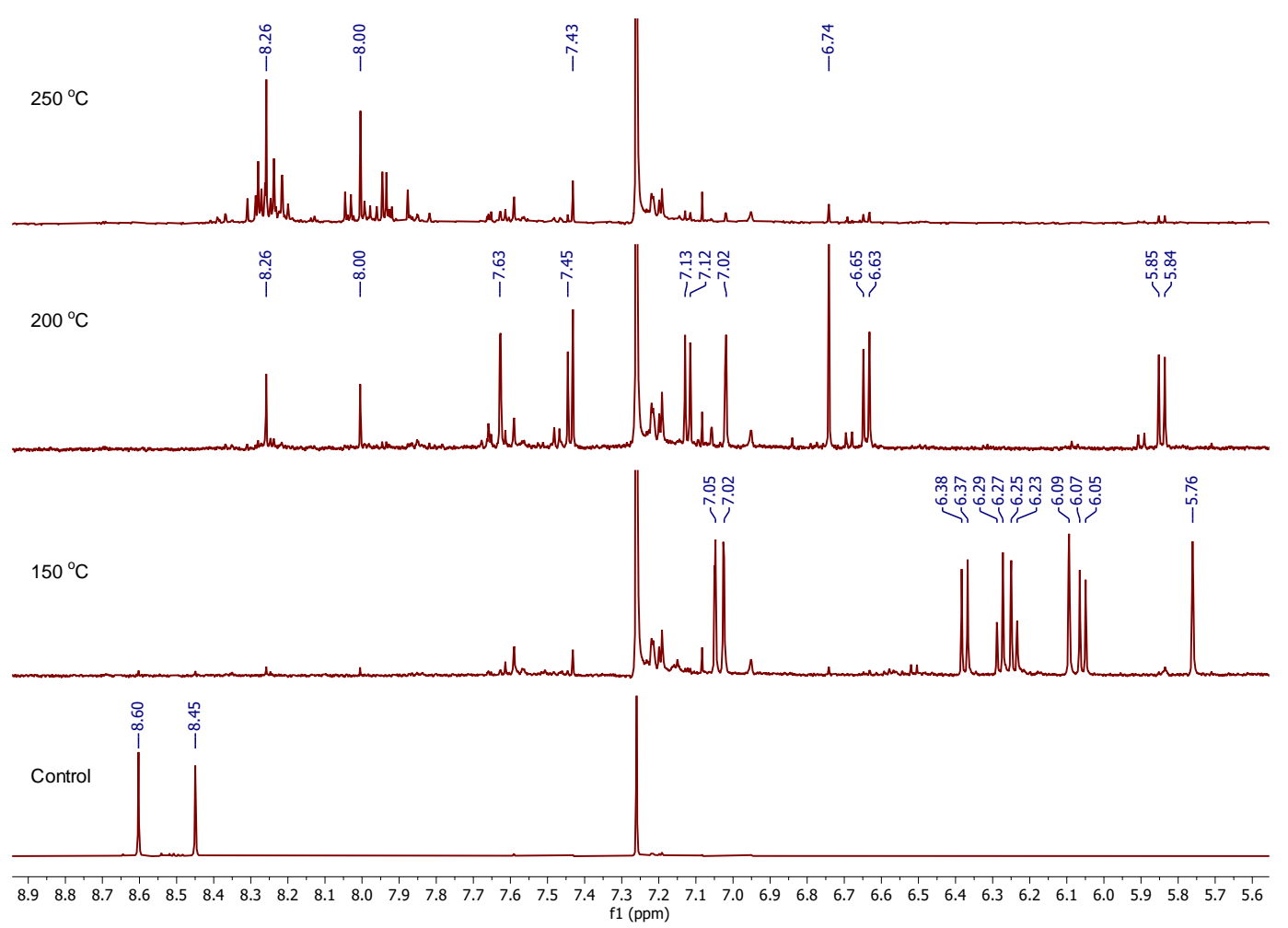

Figure S12. Overlay of the aromatic regions of samples of DHP 8 heated at different temperatures. 
In a separate experiment, we selected crystals of DHP 8 under a microscope and added them to a $5 \mathrm{~mm}$ NMR tube. The bottom of the tube was placed onto the heating stage of a Reichert melting point microscope and sample was heated gradually from room temperature to $170{ }^{\circ} \mathrm{C}$. Once the crystals had changed the color from deep purple to pale yellow, the sample was allowed to cool to room temperature, dissolved in chloroform- $d$, and analyzed by ${ }^{1} \mathrm{H}$ NMR spectroscopy.

9: Heating of a sample of DHP $8(0.2 \mathrm{mg})$, prepared as described above, to $150{ }^{\circ} \mathrm{C}$ for 5 min resulted in near quantitative conversion to 9 with some minor impurities present.

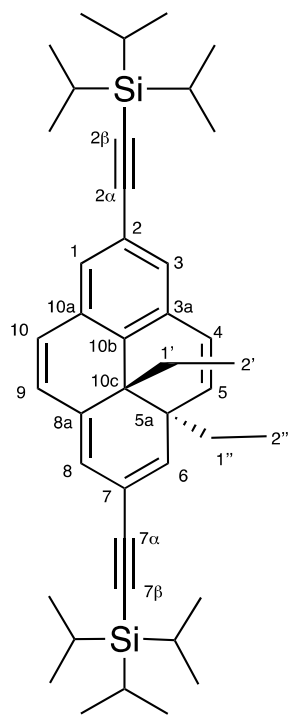

9

${ }^{1} \mathrm{H} \mathrm{NMR}\left(600 \mathrm{MHz}, \mathrm{CDCl}_{3}\right): \delta 7.07(\mathrm{~s}, 1 \mathrm{H}, \mathrm{H} 3), 7.05(\mathrm{~s}, 1 \mathrm{H}, \mathrm{H} 1), 6.39$ (d, J = 9.5 Hz, 1H, H4), 6.30 (d, J = 9.5 Hz, 1H, H9), 6.26 (d, $J=9.5$ $\mathrm{Hz}, 1 \mathrm{H}, \mathrm{H} 10), 6.12(\mathrm{~s}, 1 \mathrm{H}, \mathrm{H6}$ ), 6.07 (d, J=9.5 Hz, 1H, H5), 5.78 (s, 1H, H8), $2.19-2.12$ (m, 1H, H1'a), $2.09-2.02$ (m, 1H, H1”a), 1.97 - $1.90\left(\mathrm{~m}, 1 \mathrm{H}, \mathrm{H} 1^{\prime} \mathrm{b}\right), 1.39-1.32$ (m, 1H, H1"b), 1.15 - 1.12 (m, $42 \mathrm{H}$, TIPS $-\mathrm{CH} /-\mathrm{CH}_{3}$ ), 0.82 (td, 3H, $J=7.5,0.8 \mathrm{~Hz}, 3 \mathrm{H}, \mathrm{H} 2$ "), 0.72 $\left(\mathrm{td}, J=7.5,0.8 \mathrm{~Hz}, 3 \mathrm{H}, \mathrm{H} 2\right.$ ) ppm. ${ }^{13} \mathrm{C} \mathrm{NMR}\left(151 \mathrm{MHz}, \mathrm{CDCl}_{3}\right): \delta$ 140.7 (C8a), 138.3 (C6), 135.8 (C5), 134.8 (C10b), 133.7 (C10a), 132.2 (C3a), 129.39 (C9), 129.31 (C3), 128.9 (C1), 128.1 (C10), 125.8 (C4), 122.7 (C8), 121.7 (C2), 120.3 (C7), 107.18 (C2 $\alpha$ ), 107.10 (C7 $), 89.9$

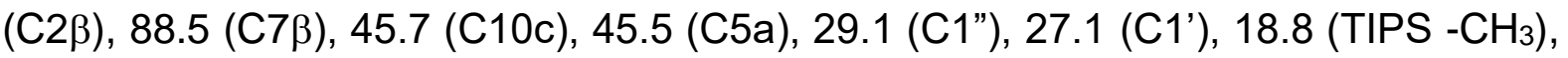
11.54 (C2"), 11.50 (TIPS -CH), 9.9 (C2') ppm.

In a separate experiment, several red crystals of DHP 8 were selected under a microscope $(\sim 1.0 \mathrm{mg})$ and added to an NMR tube. The crystal samples in the tube in 
the absence of solvent were heated on Reichert melting point microscope to $180{ }^{\circ} \mathrm{C}$ for several minutes until the color changed from deep red to pale yellow while maintaining their shape. The sample was allowed to cool down to room temperature, $\mathrm{CDCl}_{3}$ was added $(\sim 0.5 \mathrm{~mL})$, and an ${ }^{1} \mathrm{H}$ NMR spectrum was recorded, which indicated near quantitative isomerization to $\mathbf{9}$. The sample contained very small amounts of unreacted DHP 8. The conversion of 8 to 9 was $97 \%$ according to integration of the aromatic proton resonances in the ${ }^{1} \mathrm{H}$ NMR spectrum (Figure S37).

10: Heating of a sample of DHP $8(0.2 \mathrm{mg})$, prepared as described above, to $200{ }^{\circ} \mathrm{C}$ for 5 min resulted in near quantitative conversion to $\mathbf{1 0}$ with some other impurities present.

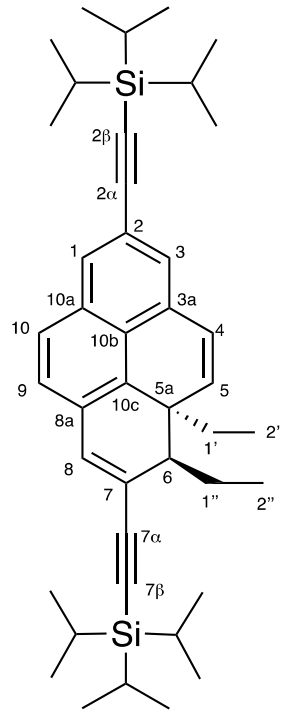

10

${ }^{1} \mathrm{H} \mathrm{NMR}\left(600 \mathrm{MHz}, \mathrm{CDCl}_{3}\right): \delta 7.65(\mathrm{~s}, 1 \mathrm{H}, \mathrm{H} 1), 7.46(\mathrm{~d}, J=8.3 \mathrm{~Hz}$, 1H, H10), 7.14 (d, J = 8.3 Hz, 1H, H9), 7.05 (s, 1H, H3), 6.77 (s, 1H, H8), $6.66(\mathrm{~d}, J=9.8 \mathrm{~Hz}, 1 \mathrm{H}, \mathrm{H} 4), 5.86(\mathrm{~d}, J=9.8 \mathrm{~Hz}, 1 \mathrm{H}, \mathrm{H} 5), 2.35$ (dd, $J=13.8,7.3 \mathrm{~Hz}, 1 \mathrm{H}, 1$ 'a), 2.30 (dd, $J=9.6,3.9 \mathrm{~Hz}, 1 \mathrm{H}, \mathrm{H} 6), 1.76$ -1.59 (m, 2H, 1"), 1.47 (dd, $\left.J=13.8,7.3 \mathrm{~Hz}, 1 \mathrm{H}, 1^{\prime} \mathrm{b}\right), 1.19-1.12$ $\left(\mathrm{m}, 42 \mathrm{H}, \mathrm{TIPS}-\mathrm{CH} / \mathrm{CH}_{3}\right), 0.97(\mathrm{t}, J=7.5 \mathrm{~Hz}, 3 \mathrm{H}, \mathrm{H} 2)$ ), $0.63(\mathrm{t}, J=7.4$ $\mathrm{Hz}, 3 \mathrm{H}, \mathrm{H} 2$ ') ppm. ${ }^{13} \mathrm{C} \mathrm{NMR}\left(151 \mathrm{MHz}, \mathrm{CDCl}_{3}\right): \delta 135.1$ (C10c), 134.9 (C5), 132.5 (C8), 132.3 (C10a), 132.0 (C3a), 131.1 (C1), 130.6 (C8a), 128.1 (C10b), 126.7 (C4), 126.2 (C9), 125.8 (C3), 125.4

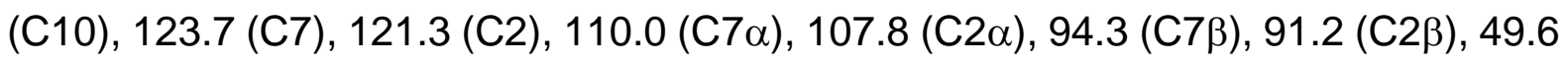
(C6), 45.8 (C5a), 33.4 (C1'), 24.6 (C1”), 19.04 - 18.87 (TIPS - $\mathrm{CH}_{3}$ ), 12.7 (C2"), 11.68 - 11.53 (TIPS -CH), 8.7 (C2') ppm. 


\section{1. ${ }^{1} \mathrm{H}$ NMR Spectrum of the Starting Material, 8}

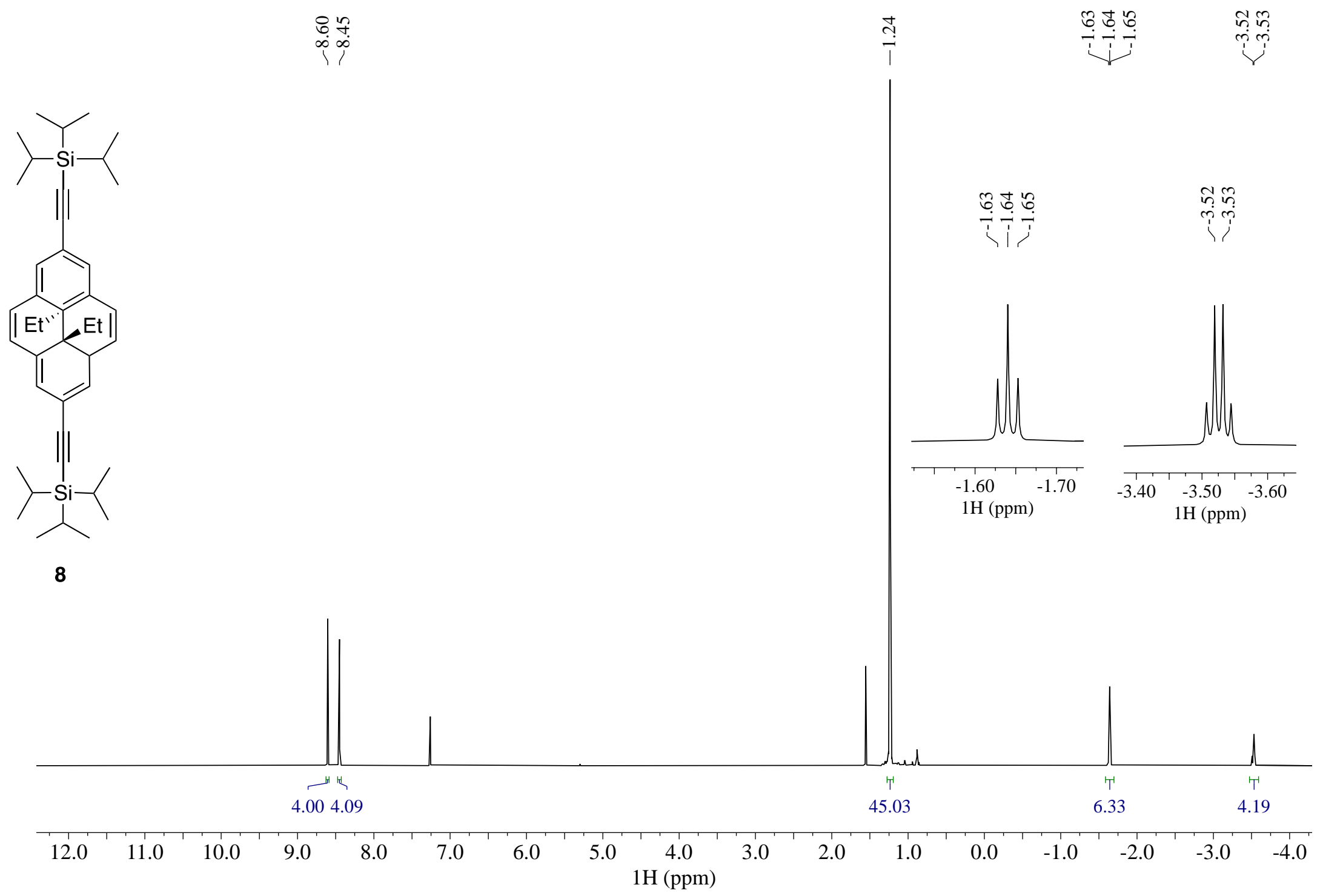

Figure S13. ${ }^{1} \mathrm{H}$ NMR spectrum of DHP 8. 


\subsection{NMR Spectra of the Heating Experiment at $150{ }^{\circ} \mathrm{C}$}

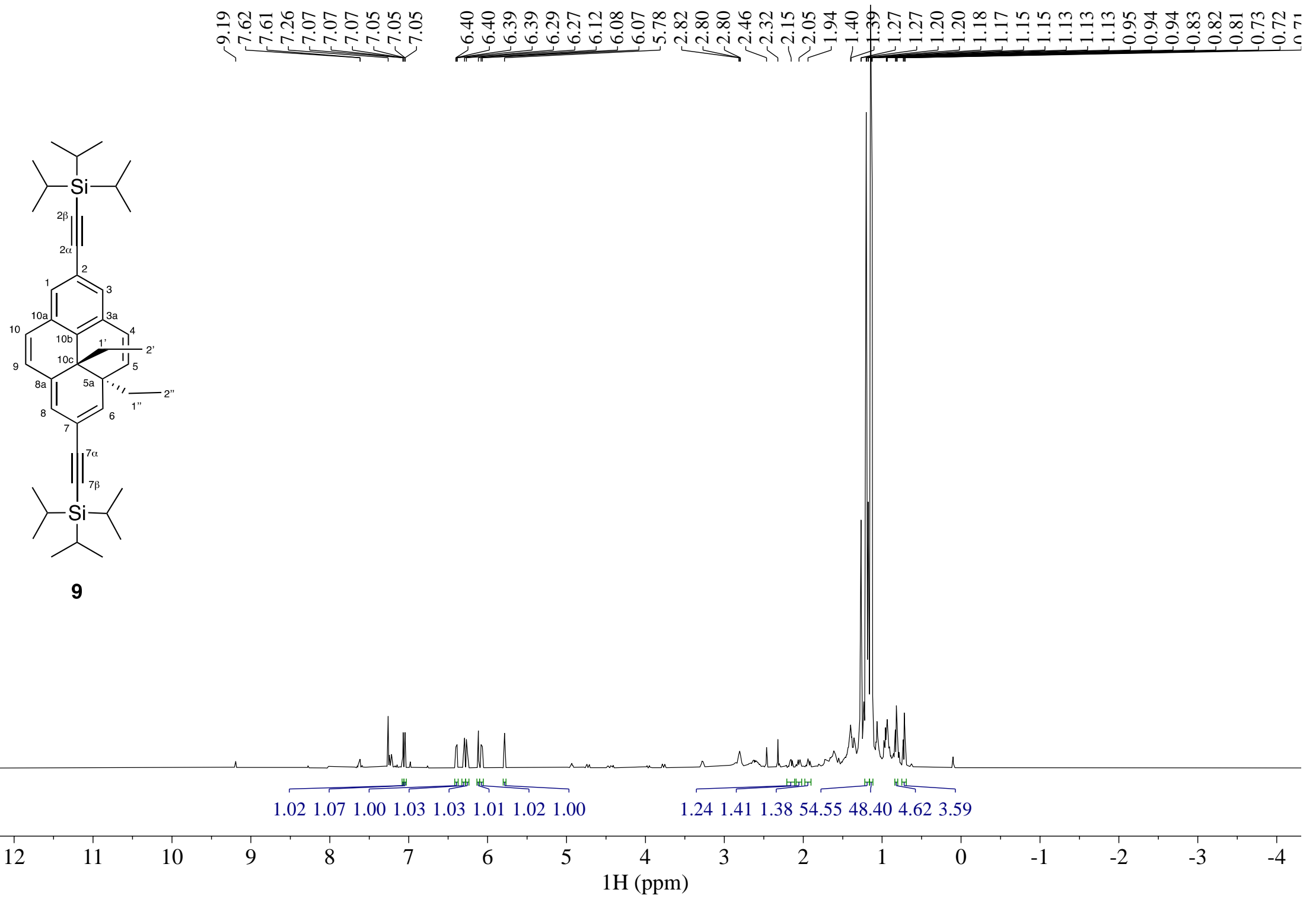

Figure S14. ${ }^{1} \mathrm{H}$ NMR spectrum of the mixture obtained from heating 8 to $150{ }^{\circ} \mathrm{C}$, containing mostly 9 . 


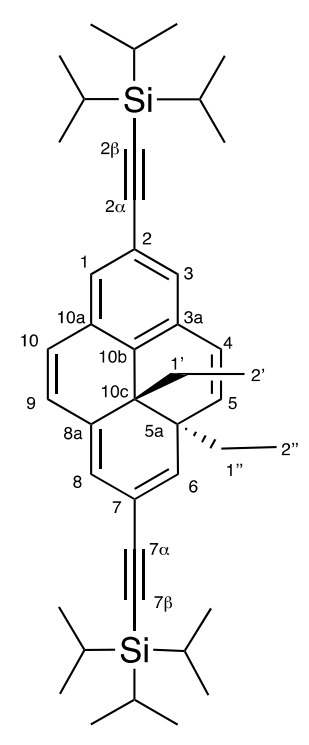

9

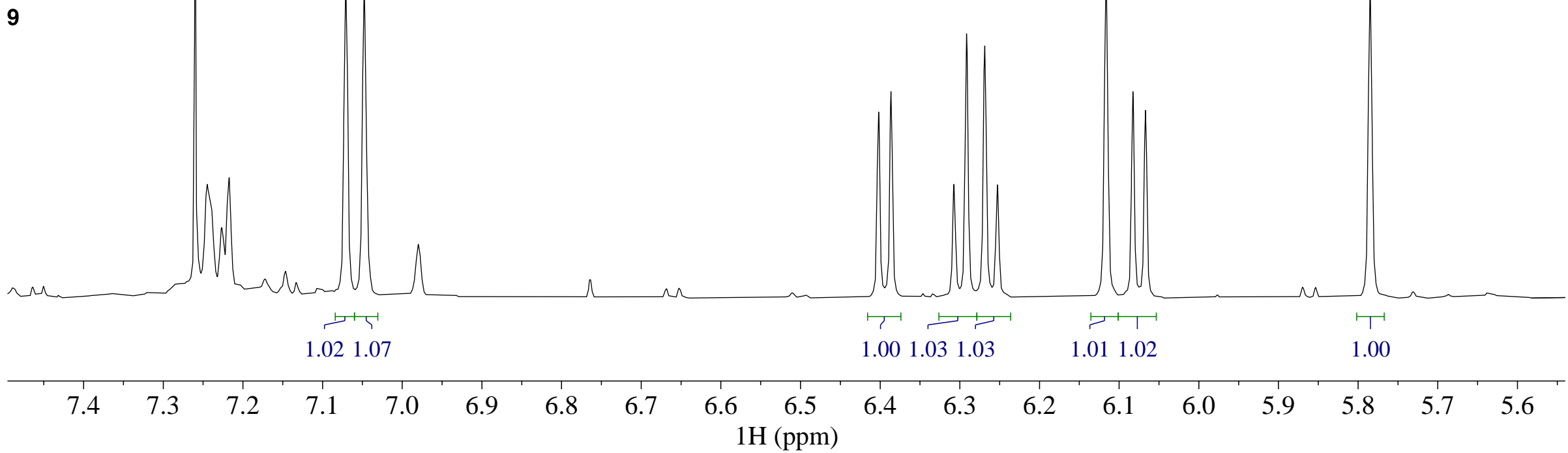

Figure S15. Selected aromatic region of the ${ }^{1} \mathrm{H}$ NMR spectrum of the mixture obtained from heating 8 to $150{ }^{\circ} \mathrm{C}$, containing mostly 9. 


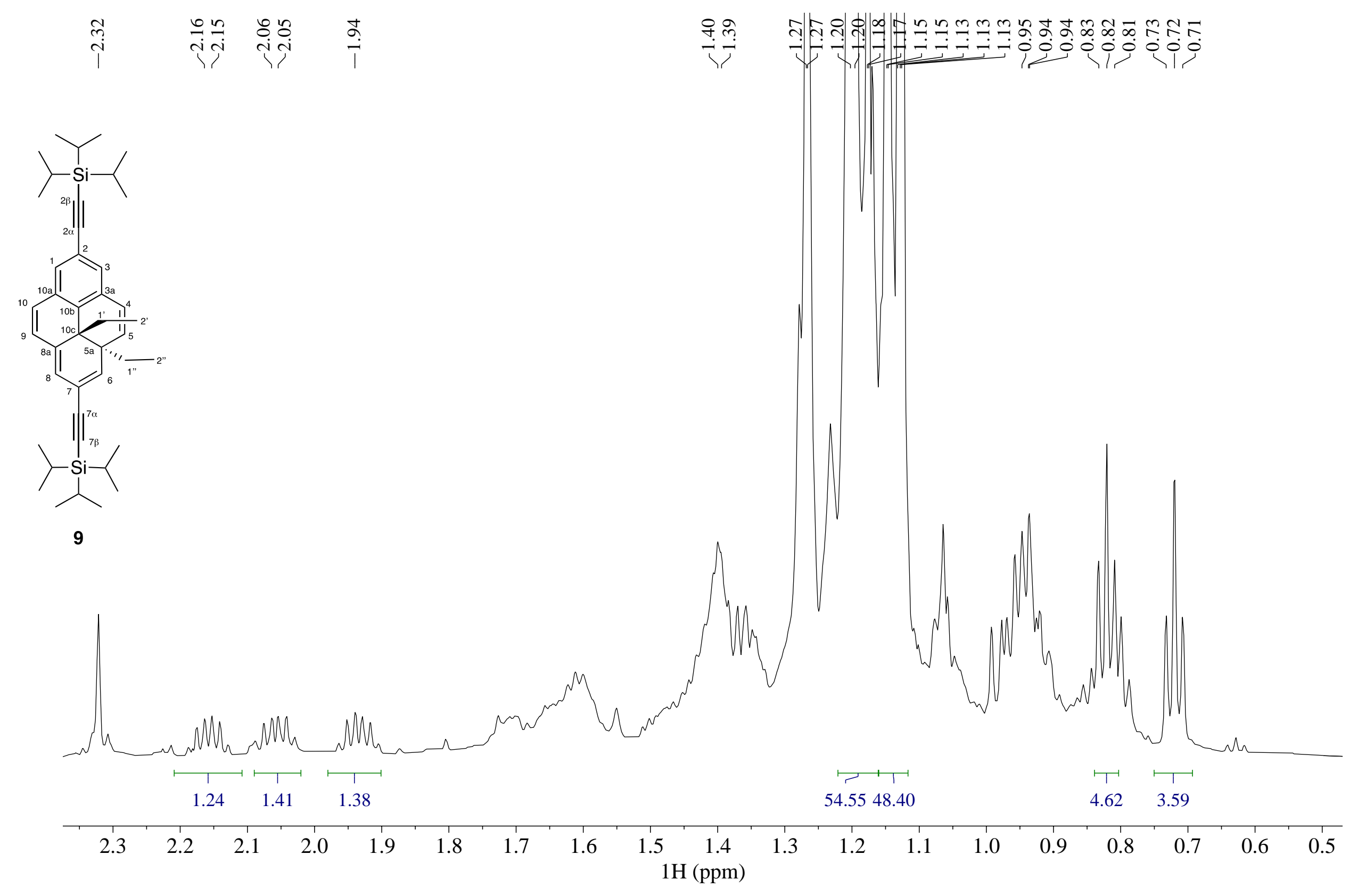

Figure S16. Selected aliphatic region of the ${ }^{1} \mathrm{H}$ NMR spectrum of the mixture obtained from heating 8 to $150{ }^{\circ} \mathrm{C}$, containing mostly 9. 


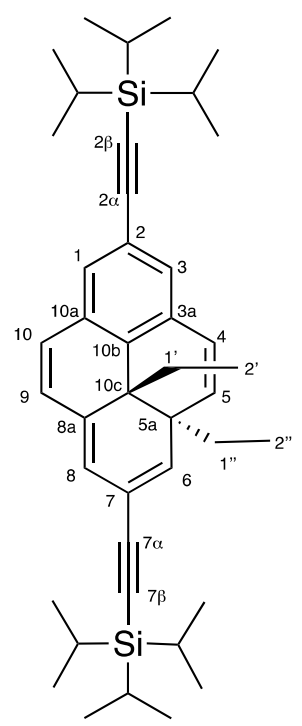

9
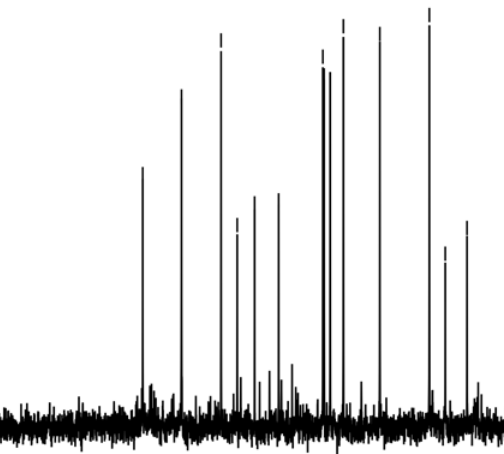

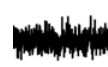

$\begin{array}{llllllllllllll}150 & 145 & 140 & 135 & 130 & 125 & 120 & 115 & 110 & 105 & 100 & 95 & 90\end{array}$ $\begin{array}{ll}9 & 85\end{array}$ $13 \mathrm{C}(\mathrm{ppm})$

Figure S17. ${ }^{13} \mathrm{C}$ NMR spectrum of the mixture obtained from heating 8 to $150{ }^{\circ} \mathrm{C}$, containing mostly 9 . 


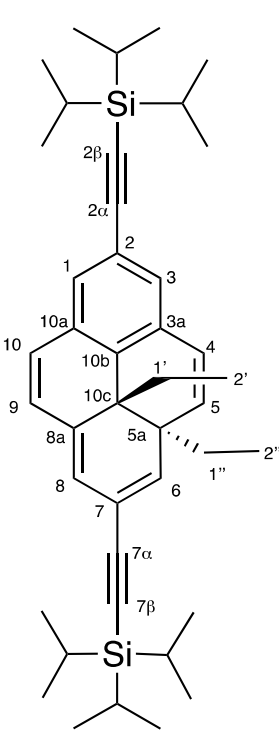

9

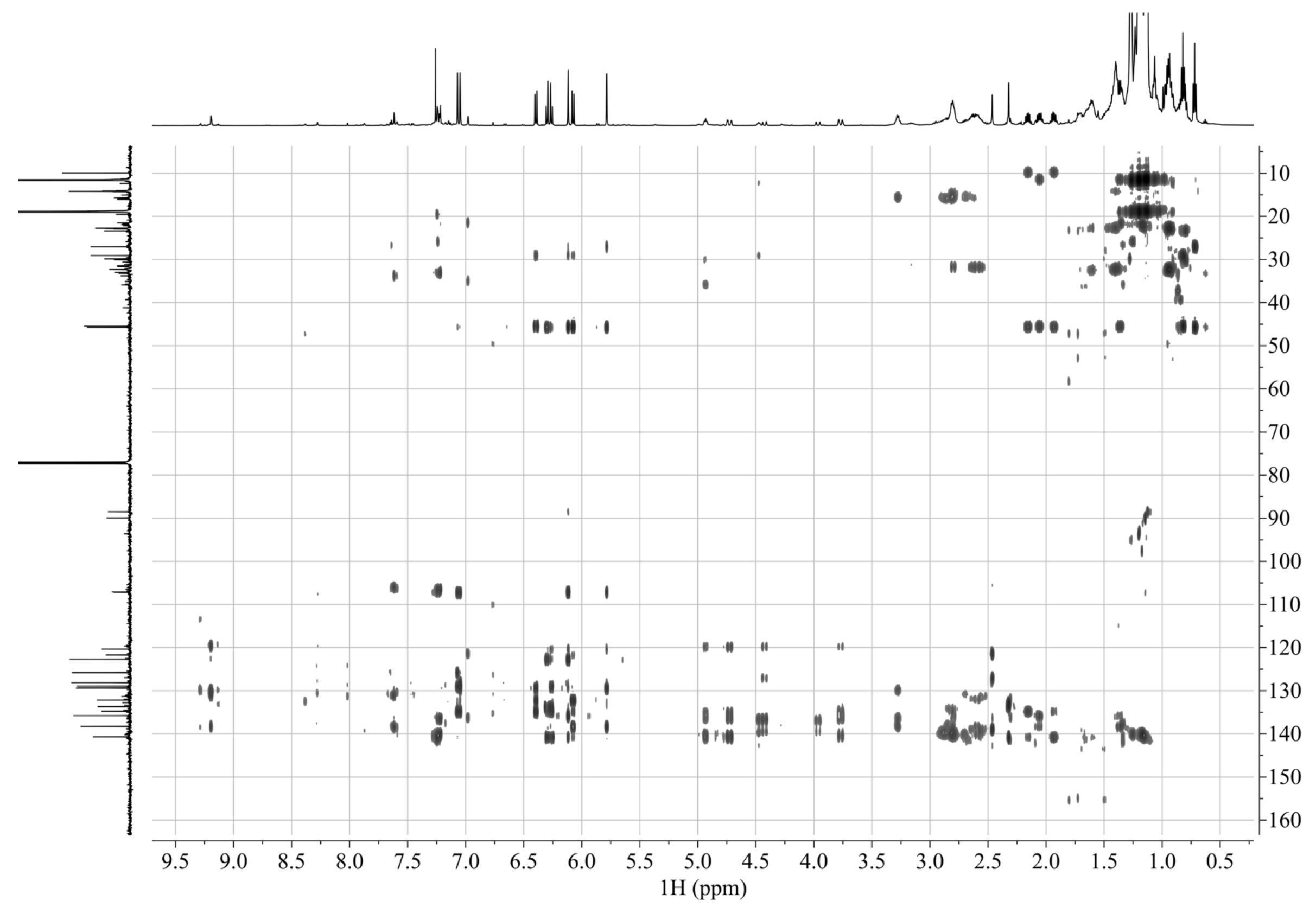

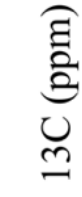

Figure S18. Full HMBC NMR spectrum of the mixture obtained from heating 8 to $150^{\circ} \mathrm{C}$, containing mostly 9 . 


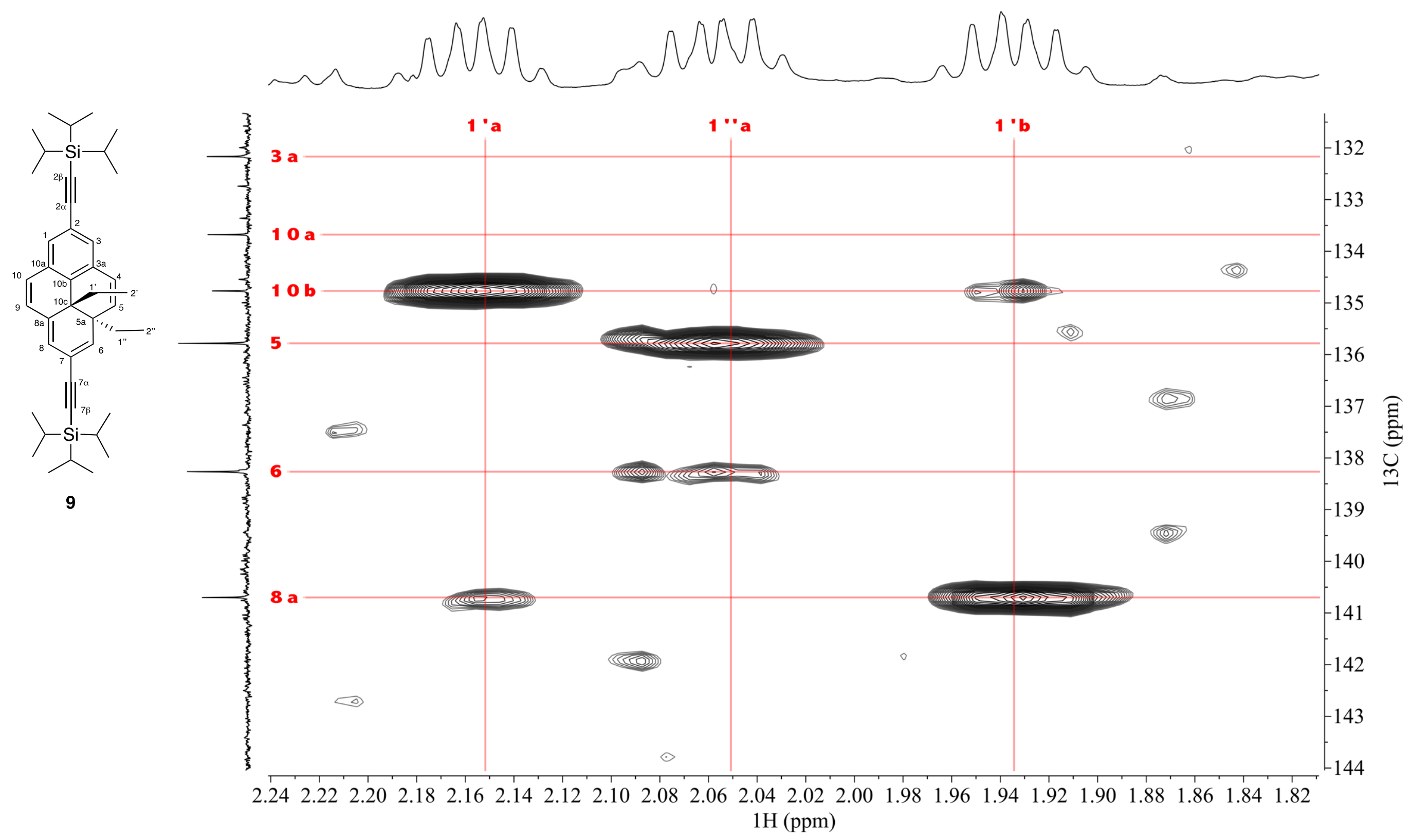

Figure S19. Selective HMBC NMR spectrum of the mixture obtained from heating 8 to $150^{\circ} \mathrm{C}$, containing mostly 9 . 


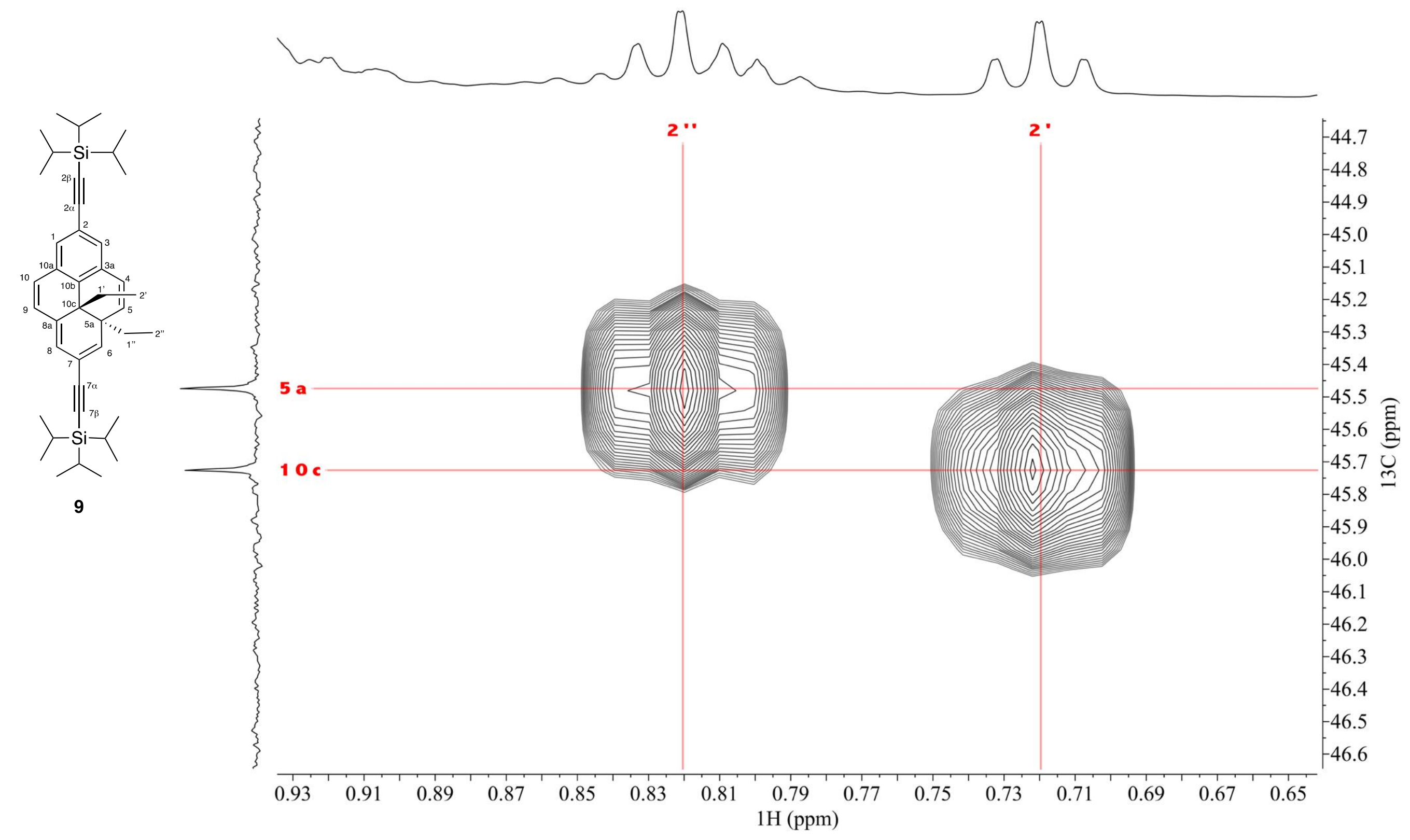

Figure S20. Selective HMBC NMR spectrum of the mixture obtained from heating 8 to $150{ }^{\circ} \mathrm{C}$, containing mostly 9 . 


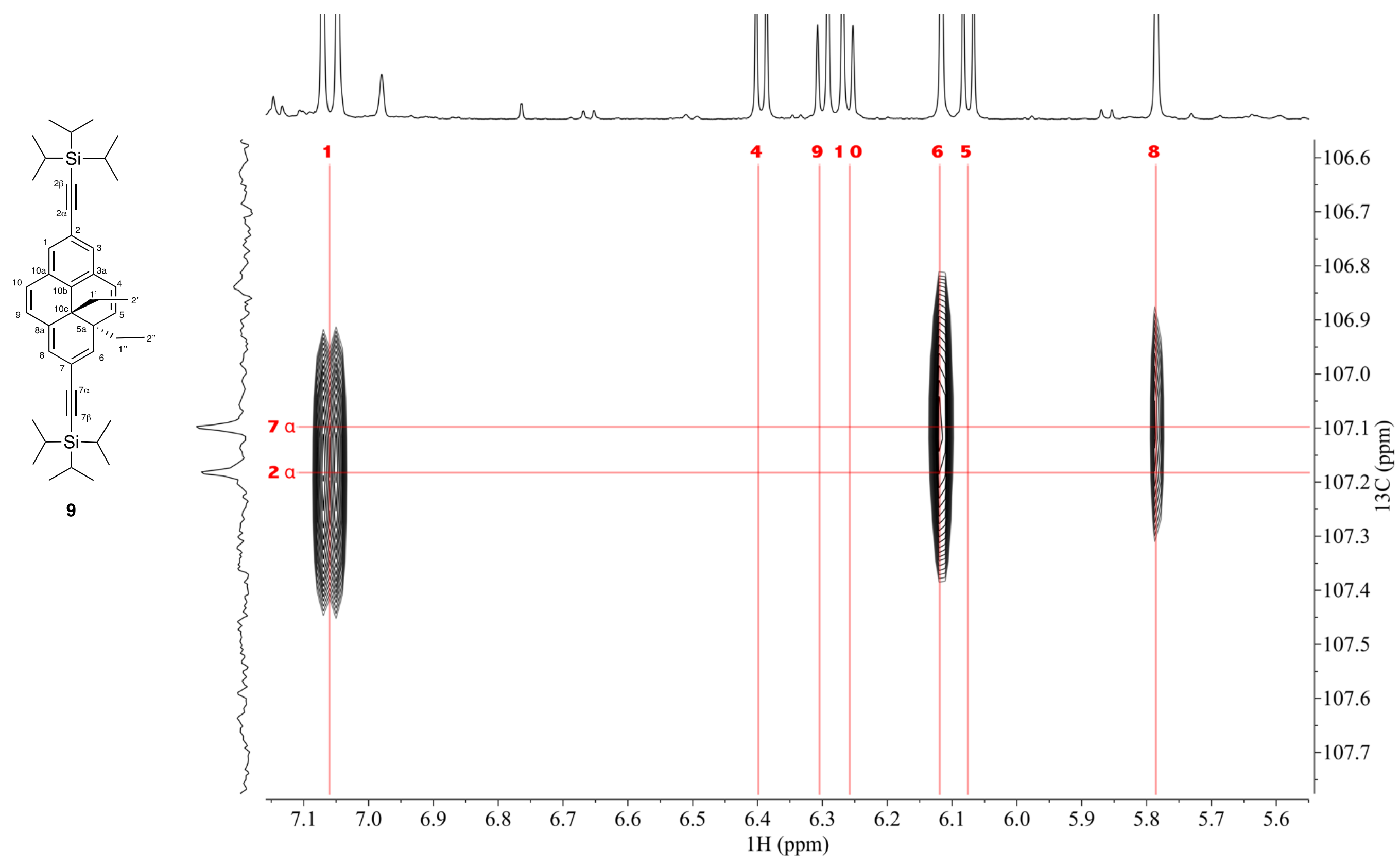

Figure S21. Selective HMBC NMR spectrum of the mixture obtained from heating 8 to $150{ }^{\circ} \mathrm{C}$, containing mostly 9 . 


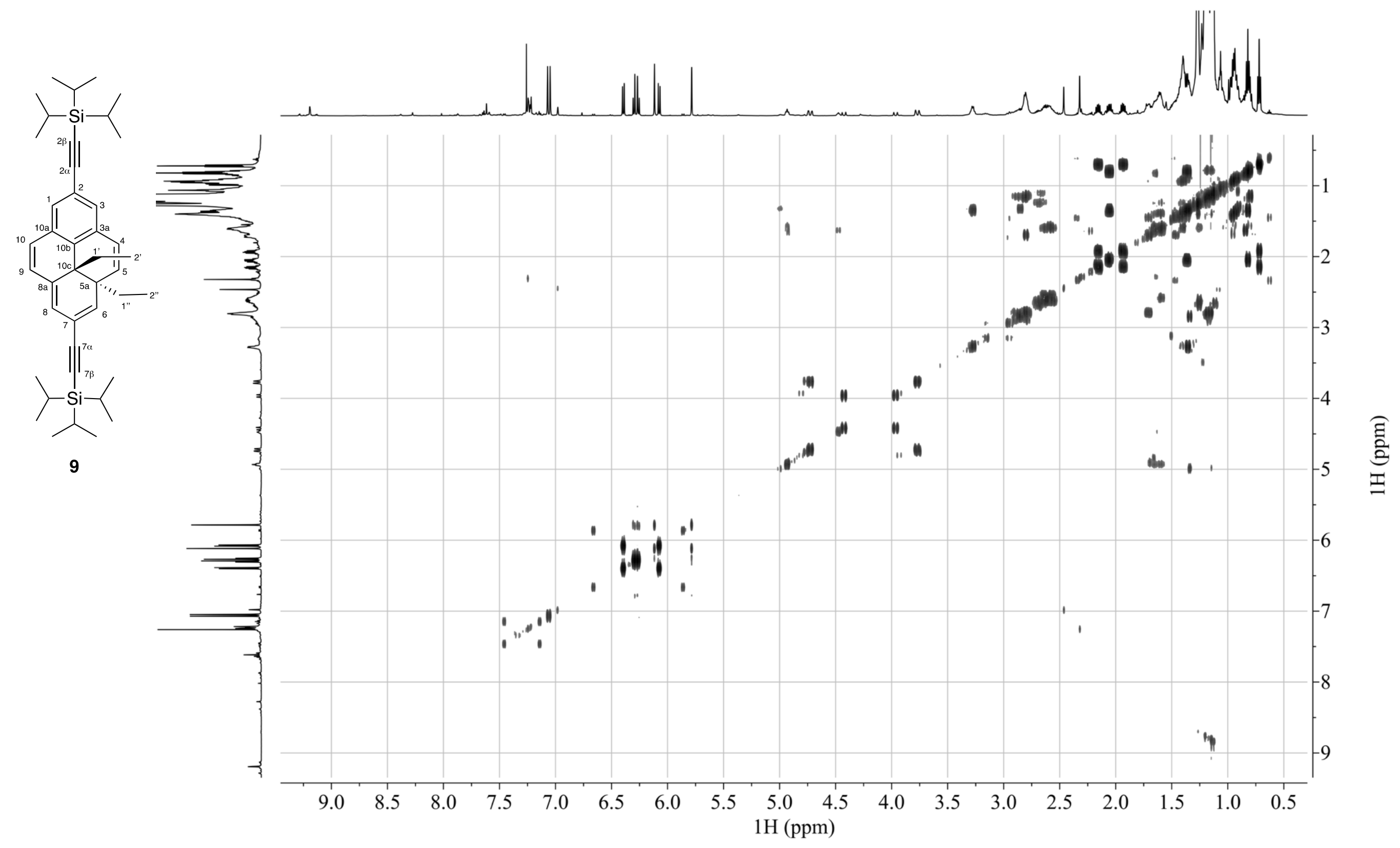

Figure S22. COSY NMR spectrum of the mixture obtained from heating 8 to $150^{\circ} \mathrm{C}$, containing mostly 9 . 


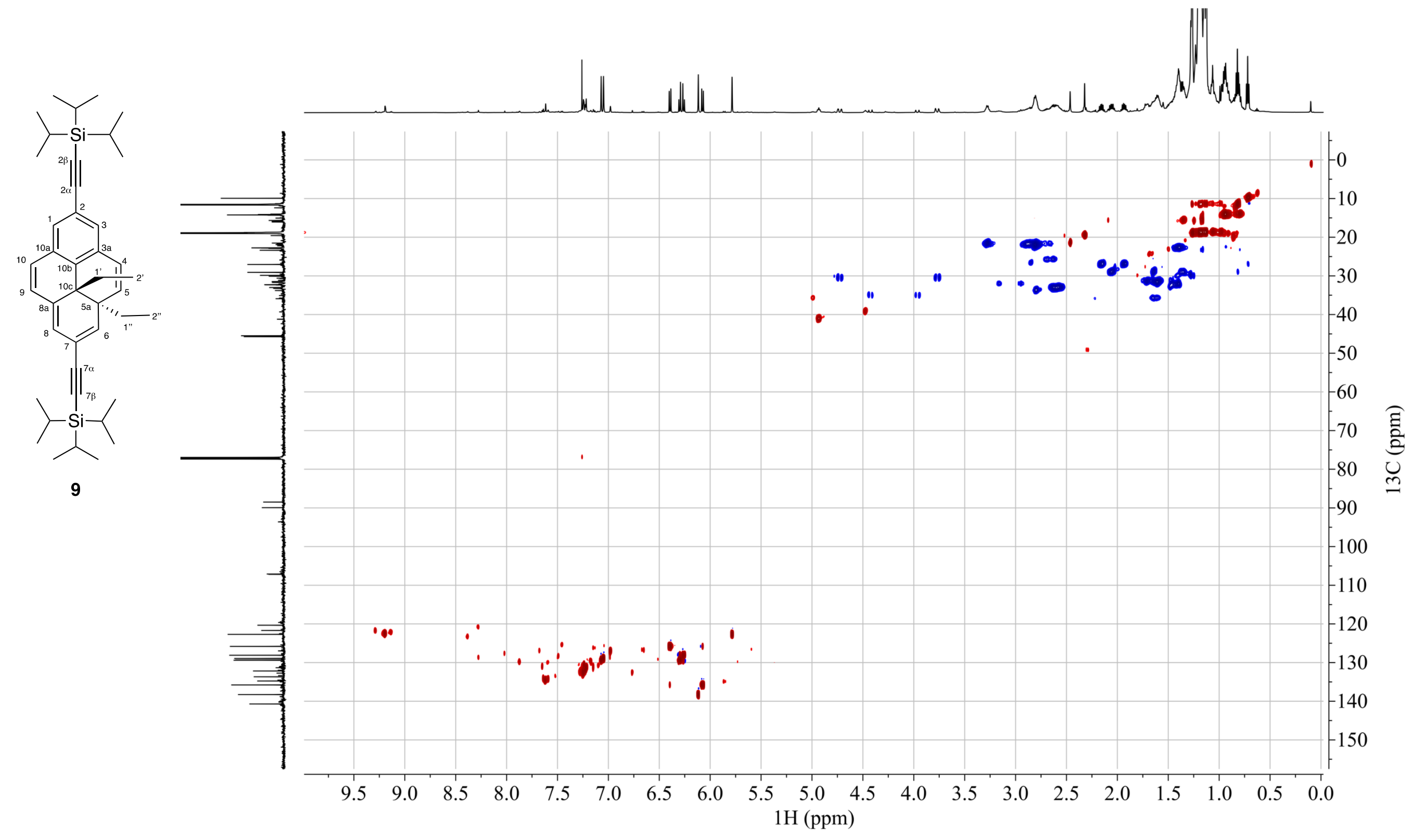

Figure S23. Full HSQC NMR spectrum of the mixture obtained from heating 8 to $150{ }^{\circ} \mathrm{C}$, containing mostly 9. Red: $\left(-\mathrm{CH}_{/}-\mathrm{CH}_{3}\right)$, blue: $\left(-\mathrm{CH}_{2}\right)$. 


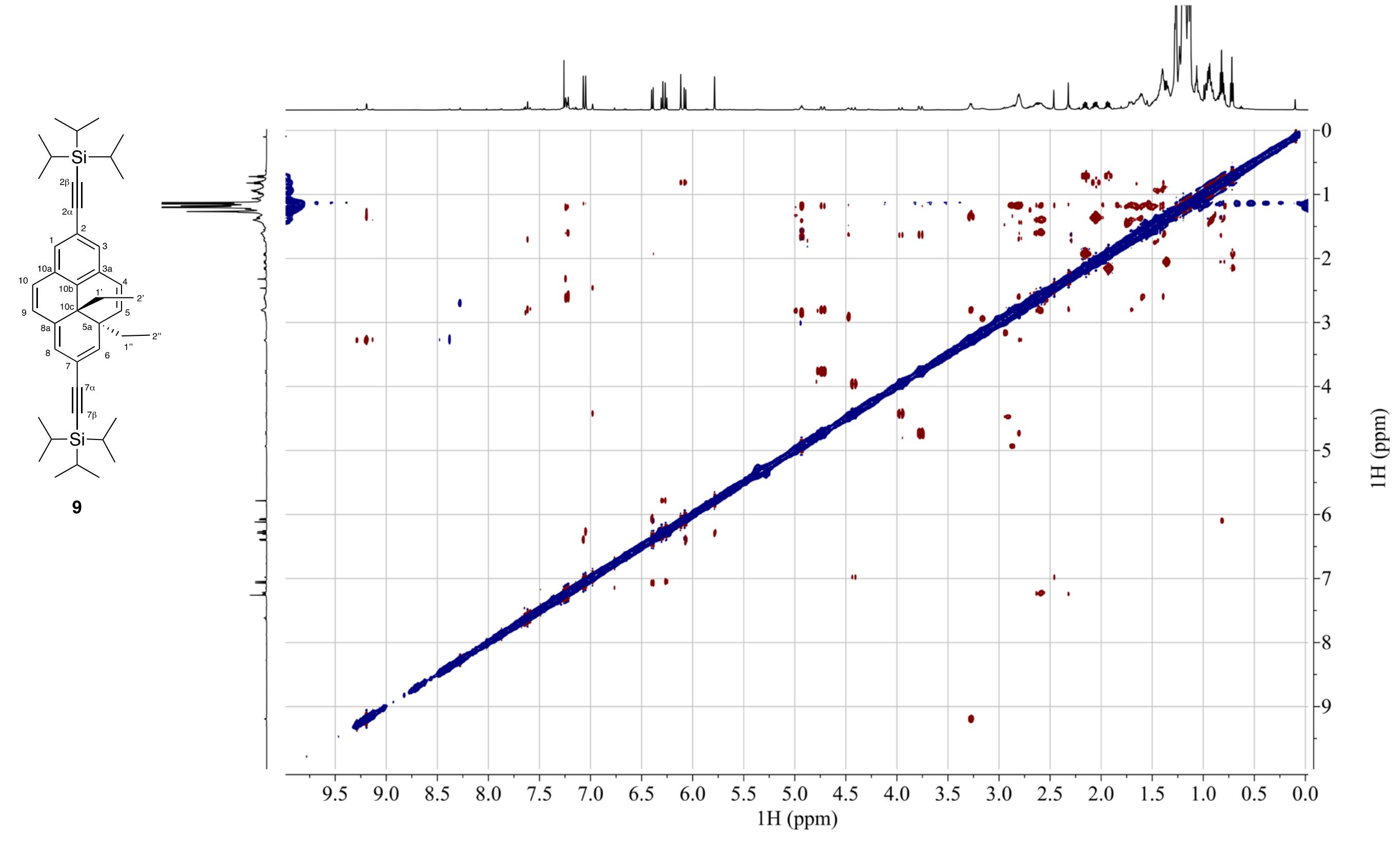

Figure S24. Full NOESY NMR spectrum of the mixture obtained from heating 8 to $150^{\circ} \mathrm{C}$, containing mostly 9 . 


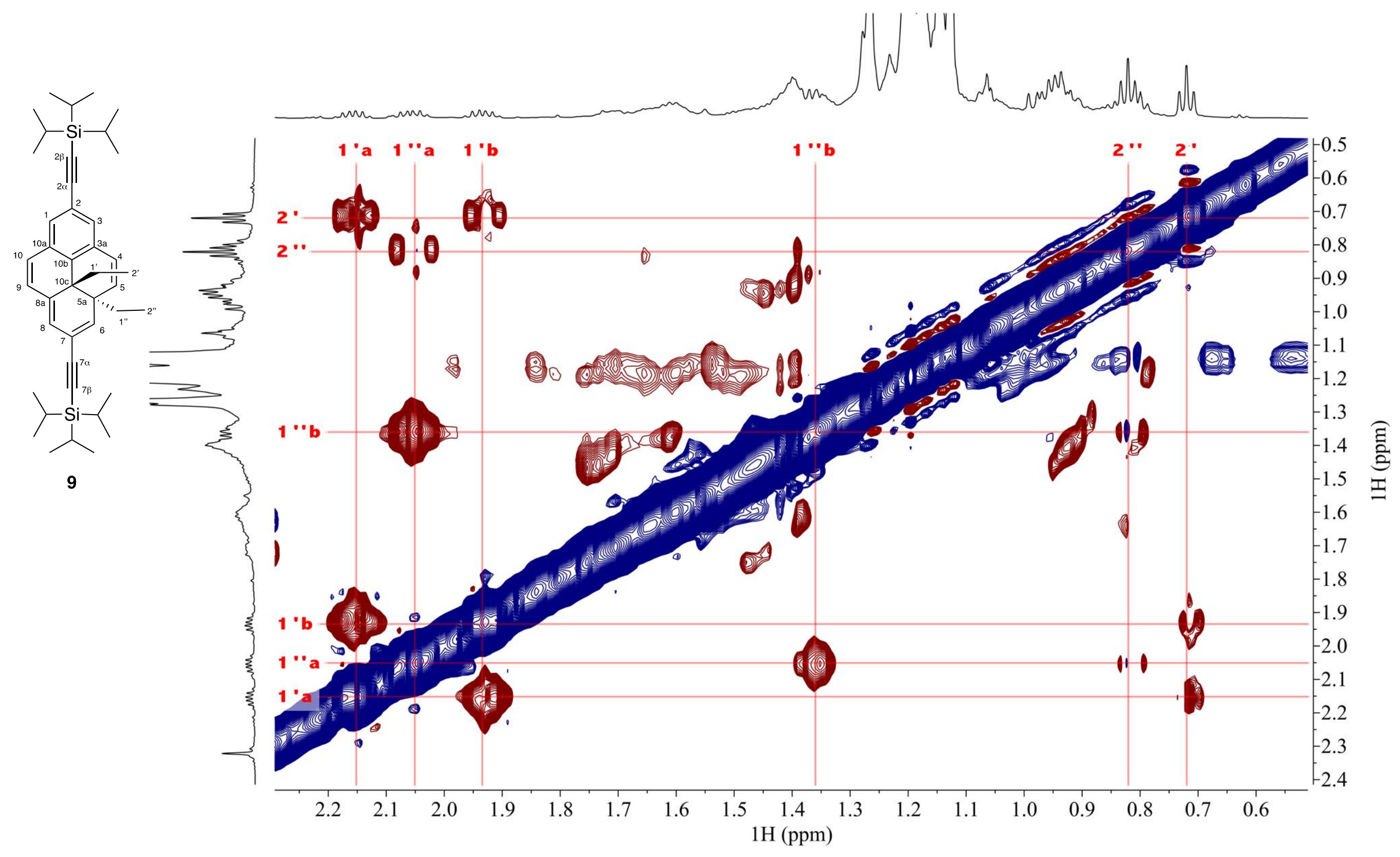

Figure S25. Full NOESY NMR spectrum of the mixture obtained from heating 8 to $150^{\circ} \mathrm{C}$, containing mostly 9 . 


\subsection{NMR Spectra of the Heating Experiment at $200{ }^{\circ} \mathrm{C}$}
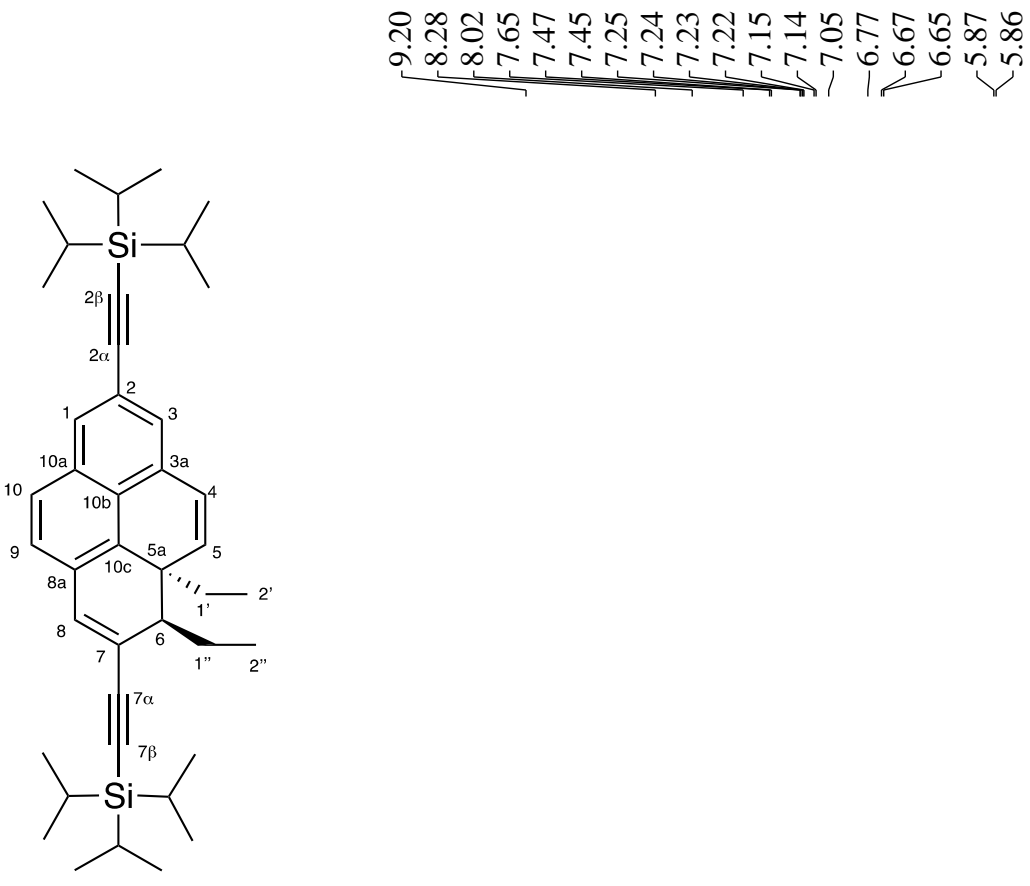

10

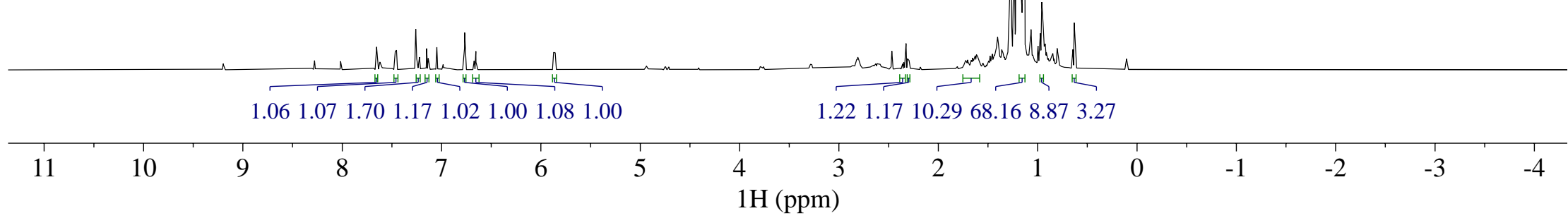

Figure S26. ${ }^{1} \mathrm{H}$ NMR spectrum of the mixture obtained from heating 8 to $200^{\circ} \mathrm{C}$, containing mostly 10 . 

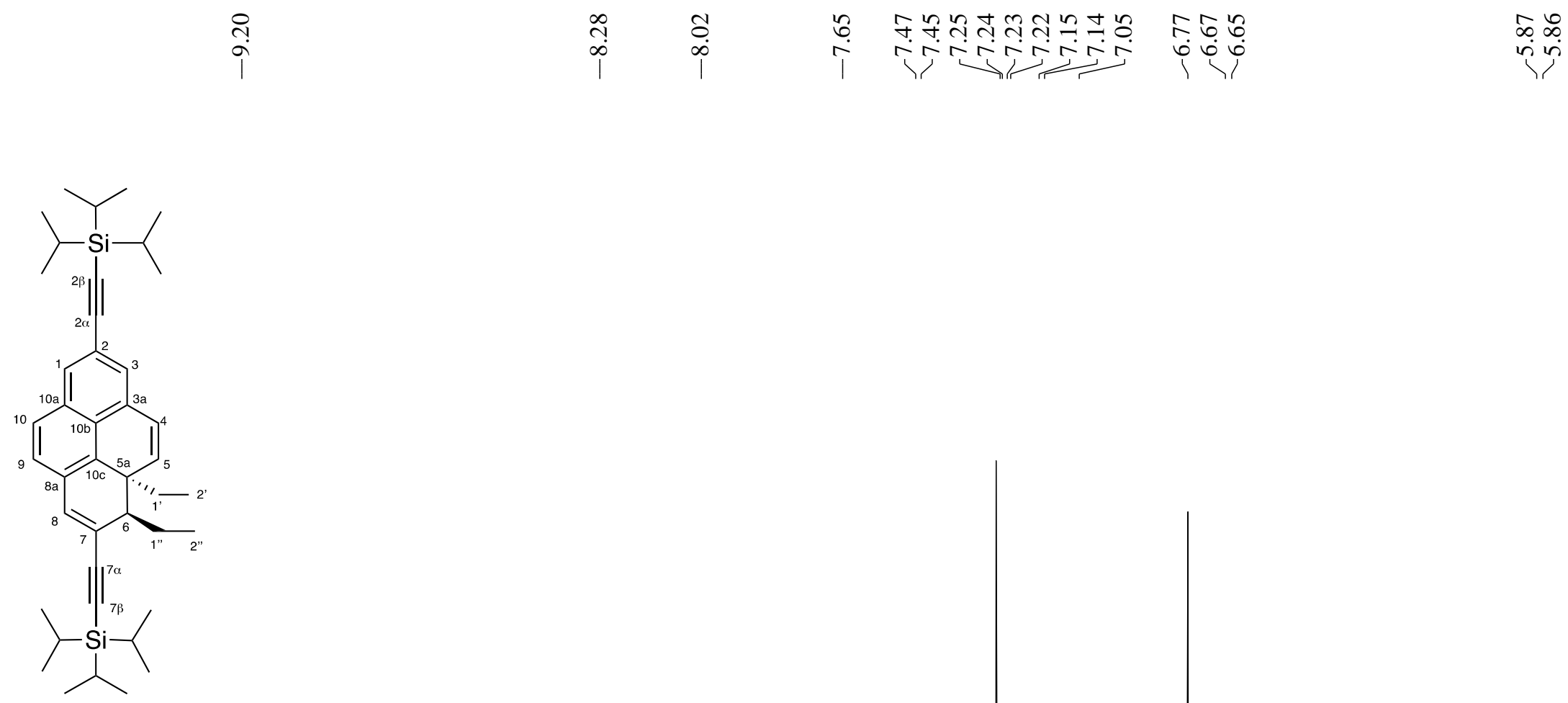

10

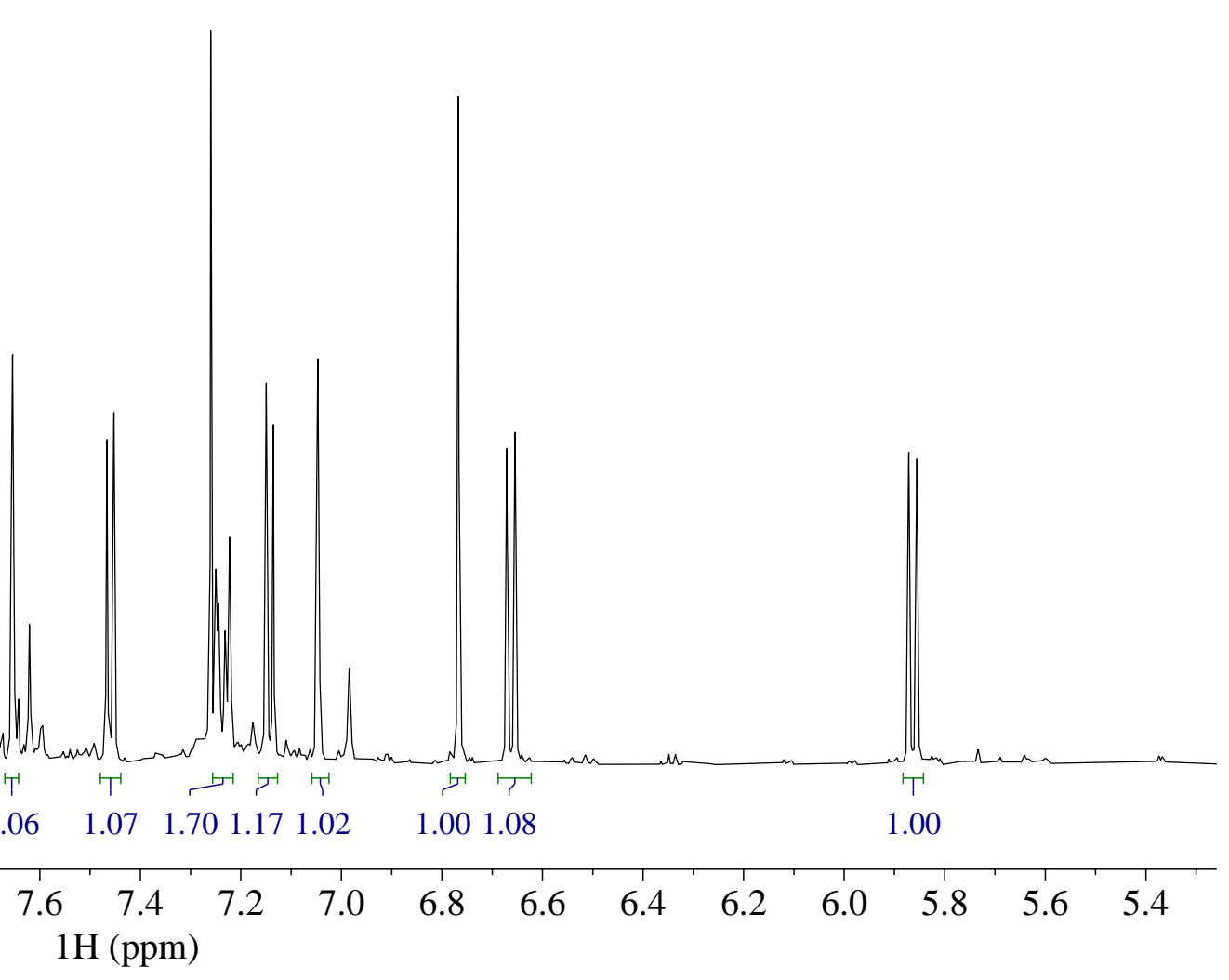

Figure S27. Selected aromatic region of the ${ }^{1} \mathrm{H}$ NMR spectrum of the mixture obtained from heating 8 to $200{ }^{\circ} \mathrm{C}$, containing mostly 10 . 


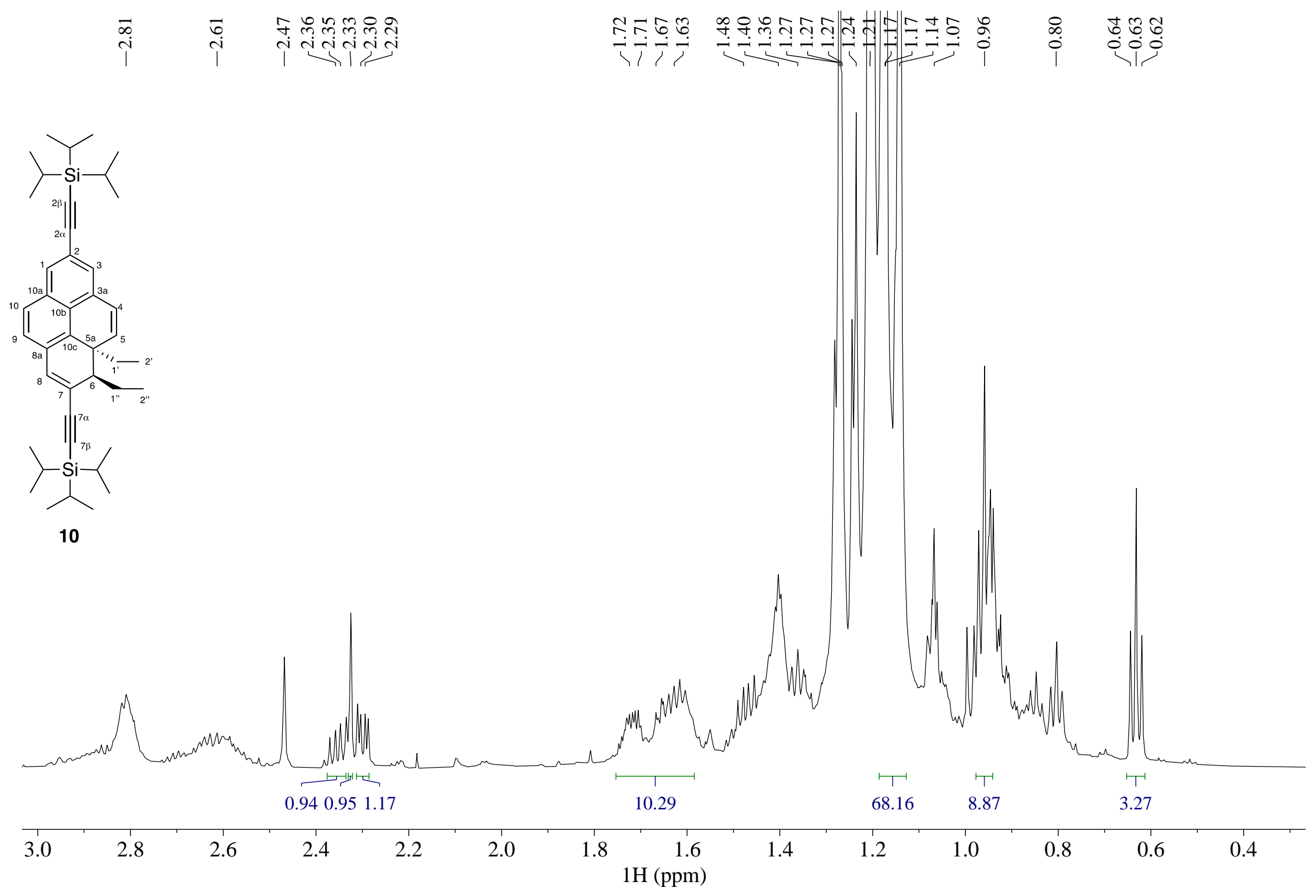

Figure S28. Selected aliphatic region of the ${ }^{1} \mathrm{H}$ NMR spectrum of the mixture obtained from heating 8 to $200{ }^{\circ} \mathrm{C}$, containing mostly 10 . 

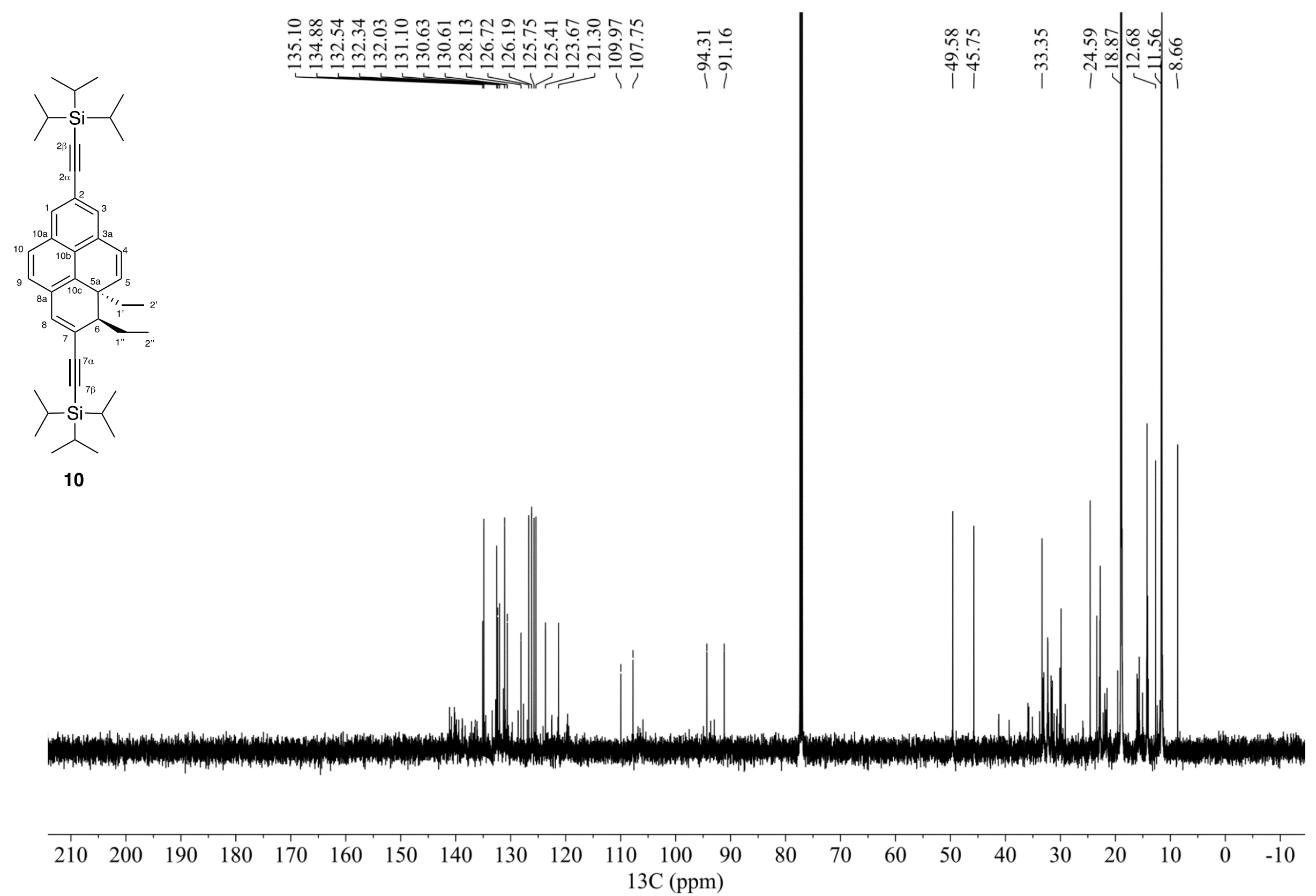

Figure S29. ${ }^{13} \mathrm{C}$ NMR spectrum of the mixture obtained from heating 8 to $200^{\circ} \mathrm{C}$, containing mostly 10 . 


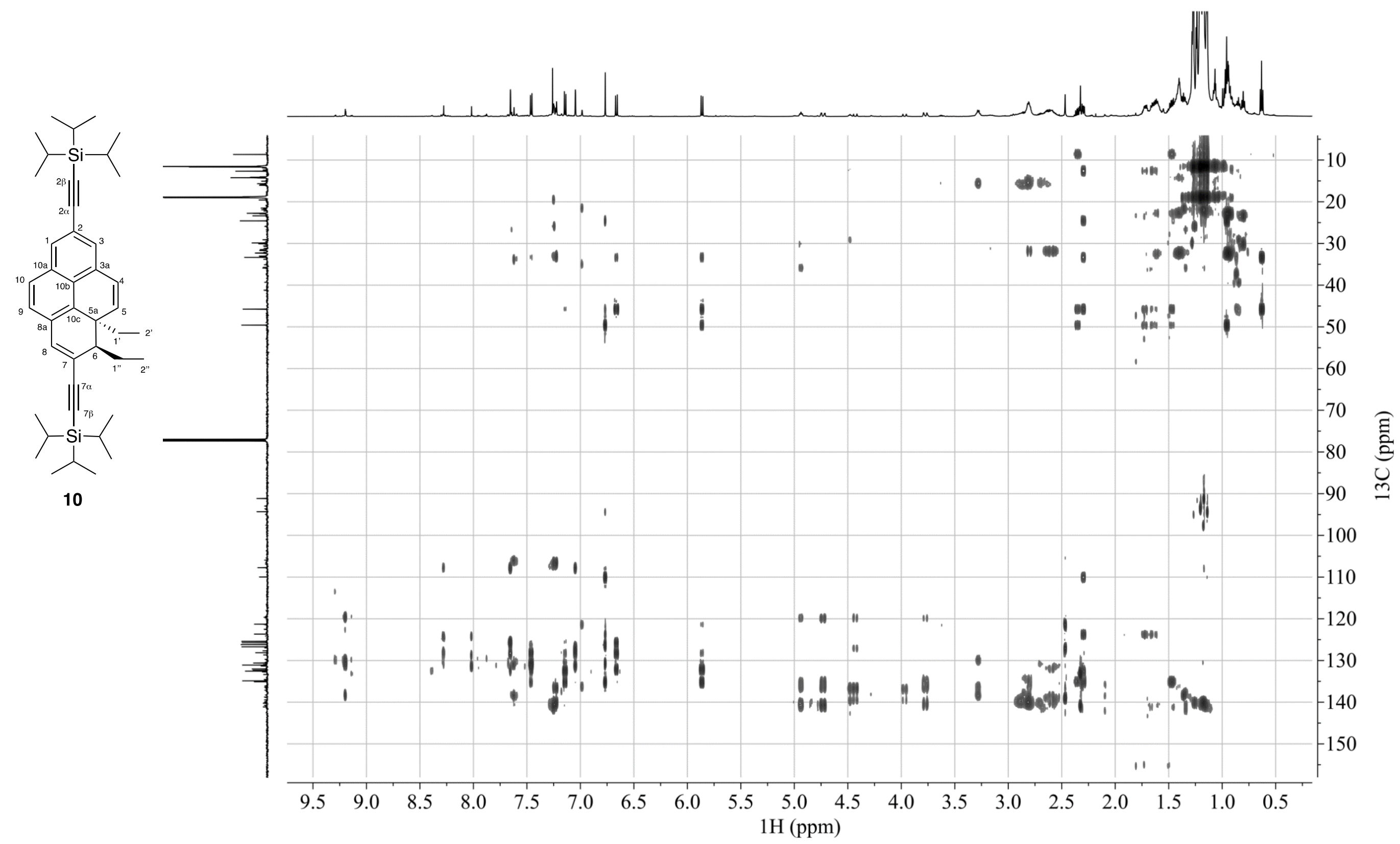

Figure S30. Full HMBC NMR spectrum of the mixture obtained from heating 8 to $200^{\circ} \mathrm{C}$, containing mostly 10 . 


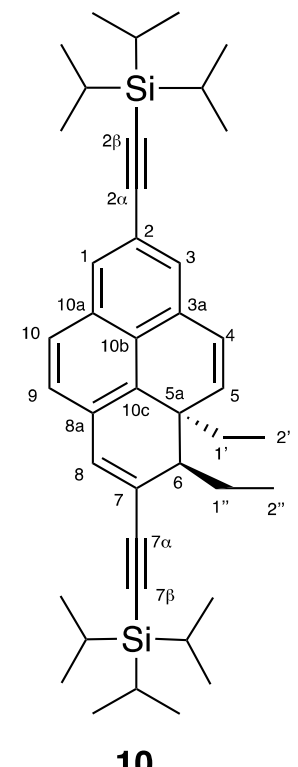

10

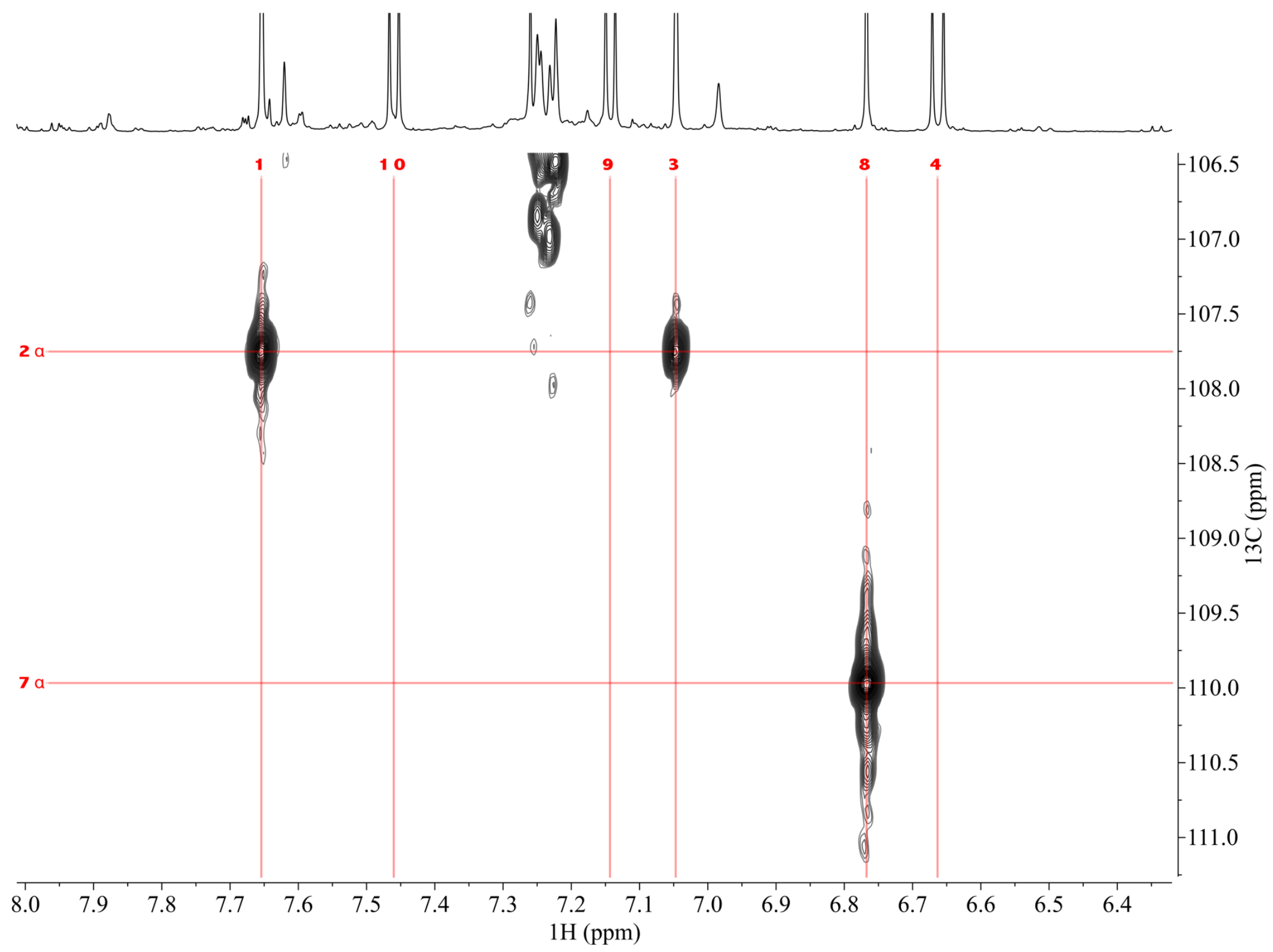

Figure S31. Selective HMBC NMR spectrum of the mixture obtained from heating 8 to $200{ }^{\circ} \mathrm{C}$, containing mostly 10 . 


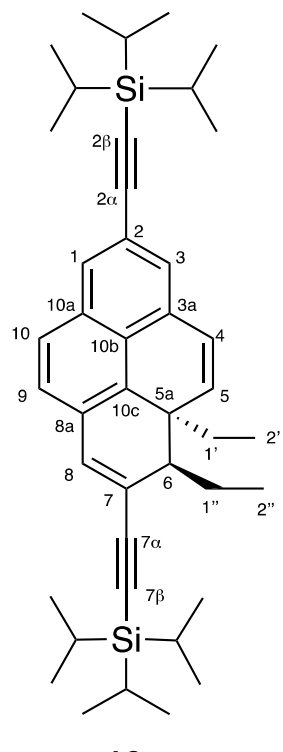

10

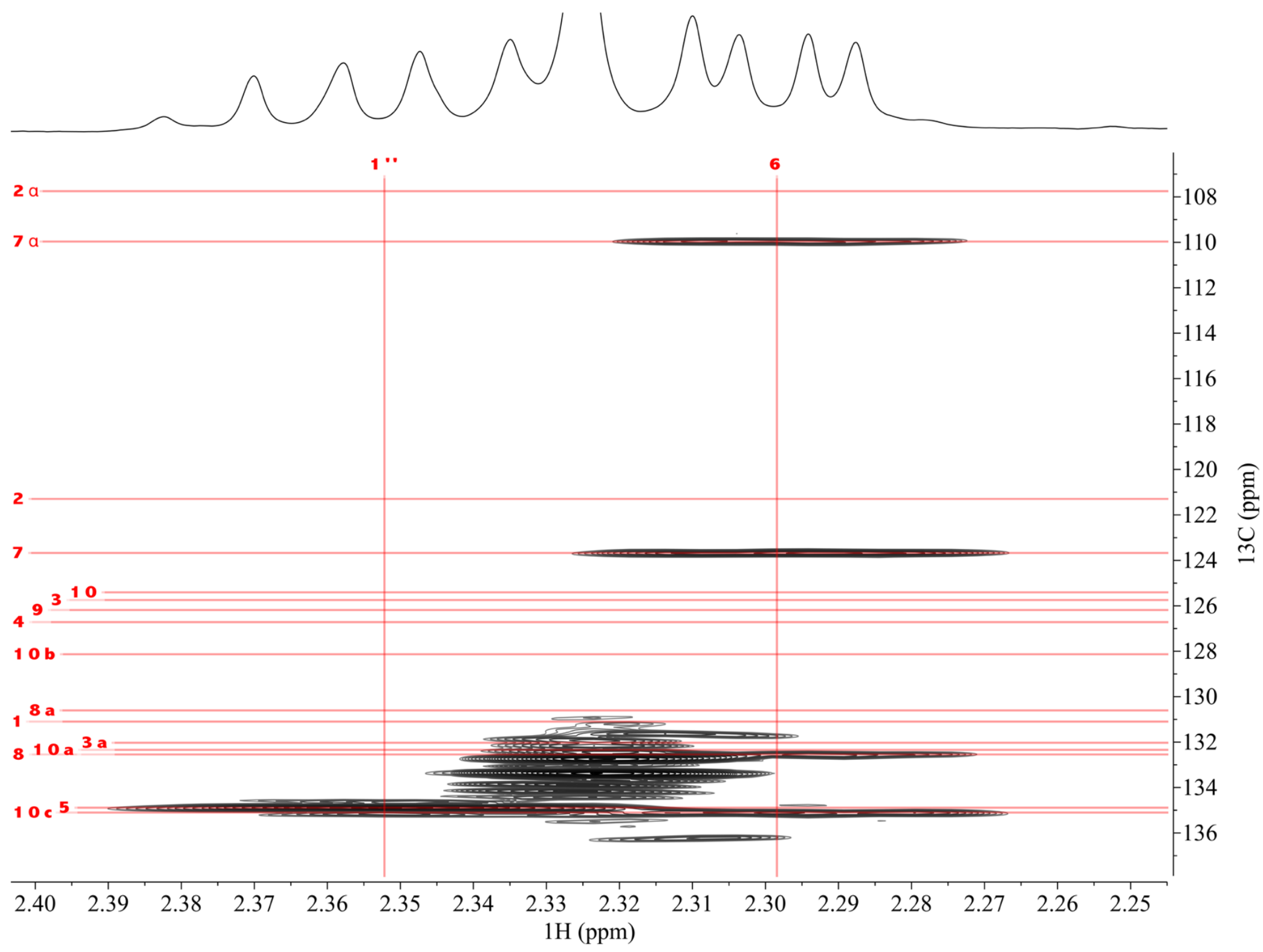

Figure S32. Selective HMBC NMR spectrum of the mixture obtained from heating 8 to $200^{\circ} \mathrm{C}$, containing mostly 10 . 


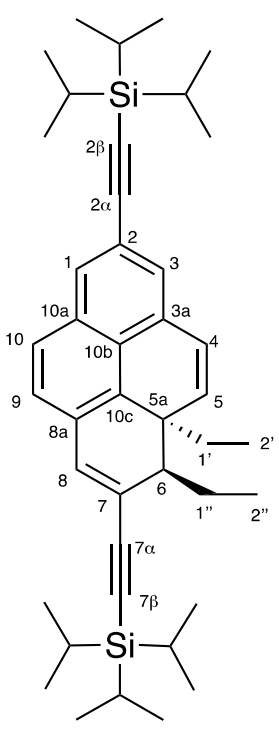

10

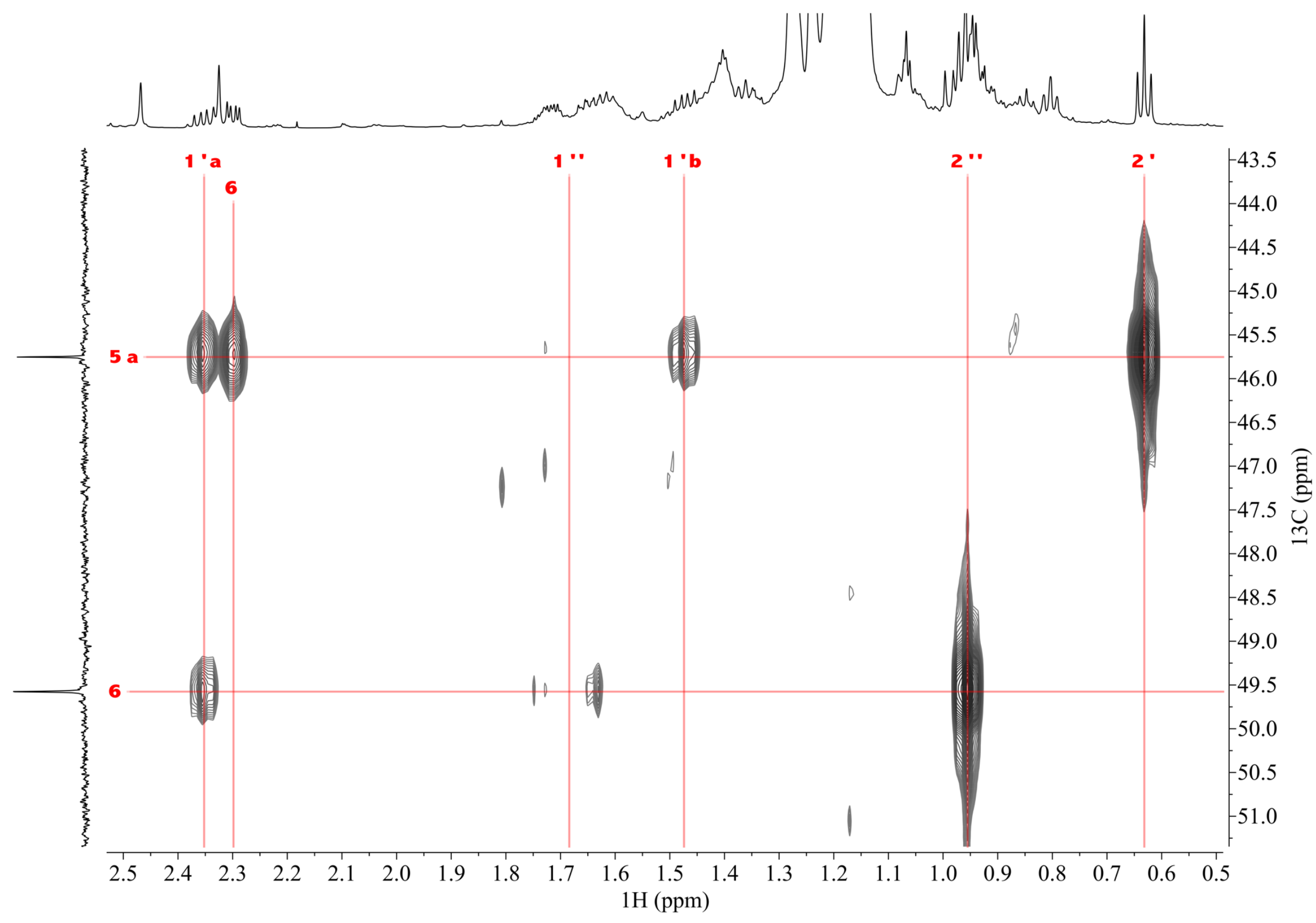

Figure S33. Selective HMBC NMR spectrum of the mixture obtained from heating 8 to $200^{\circ} \mathrm{C}$, containing mostly 10 . 


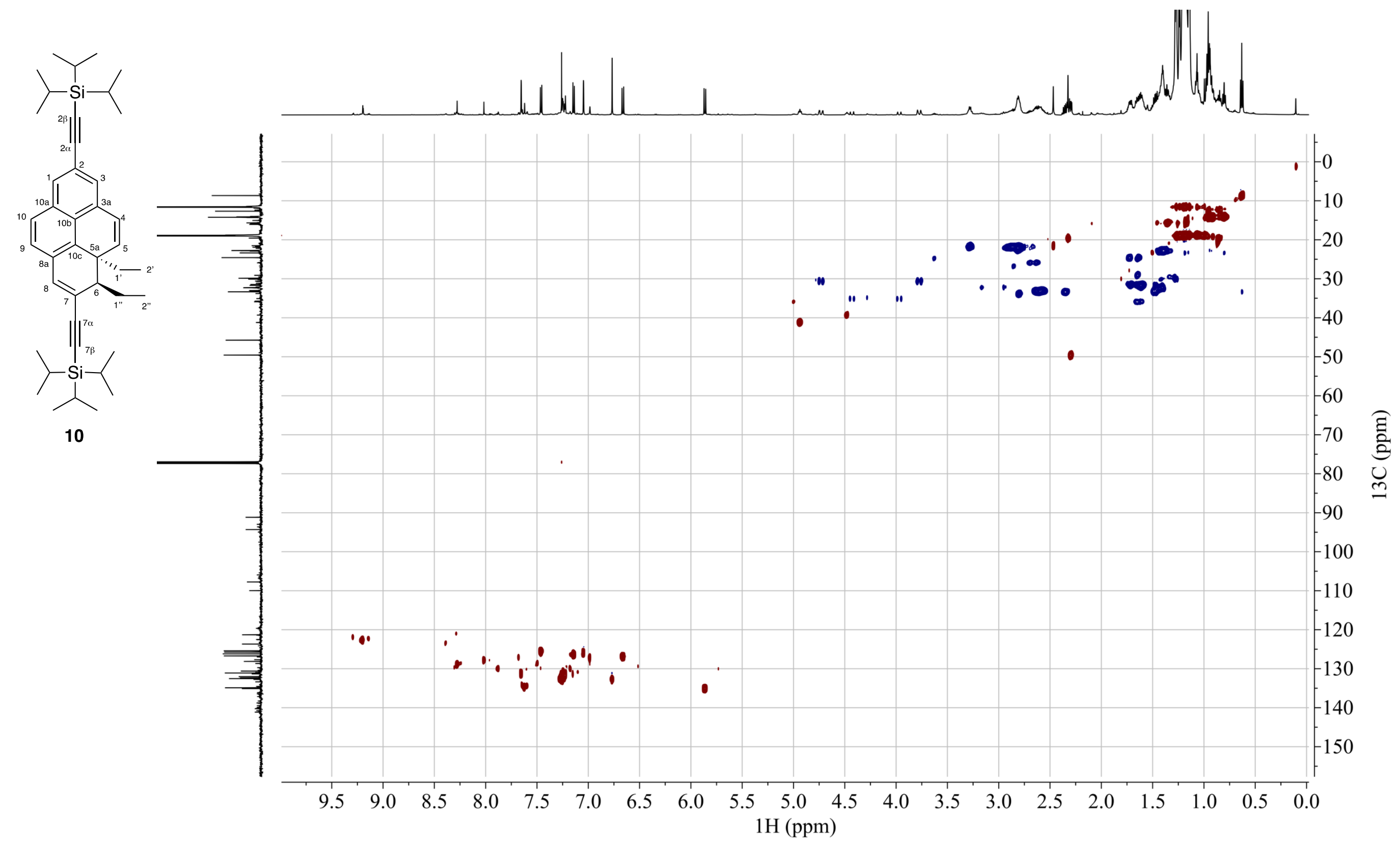

Figure S34. Full HSQC NMR spectrum of the mixture obtained from heating 8 to $200{ }^{\circ} \mathrm{C}$, containing mostly 10 . 


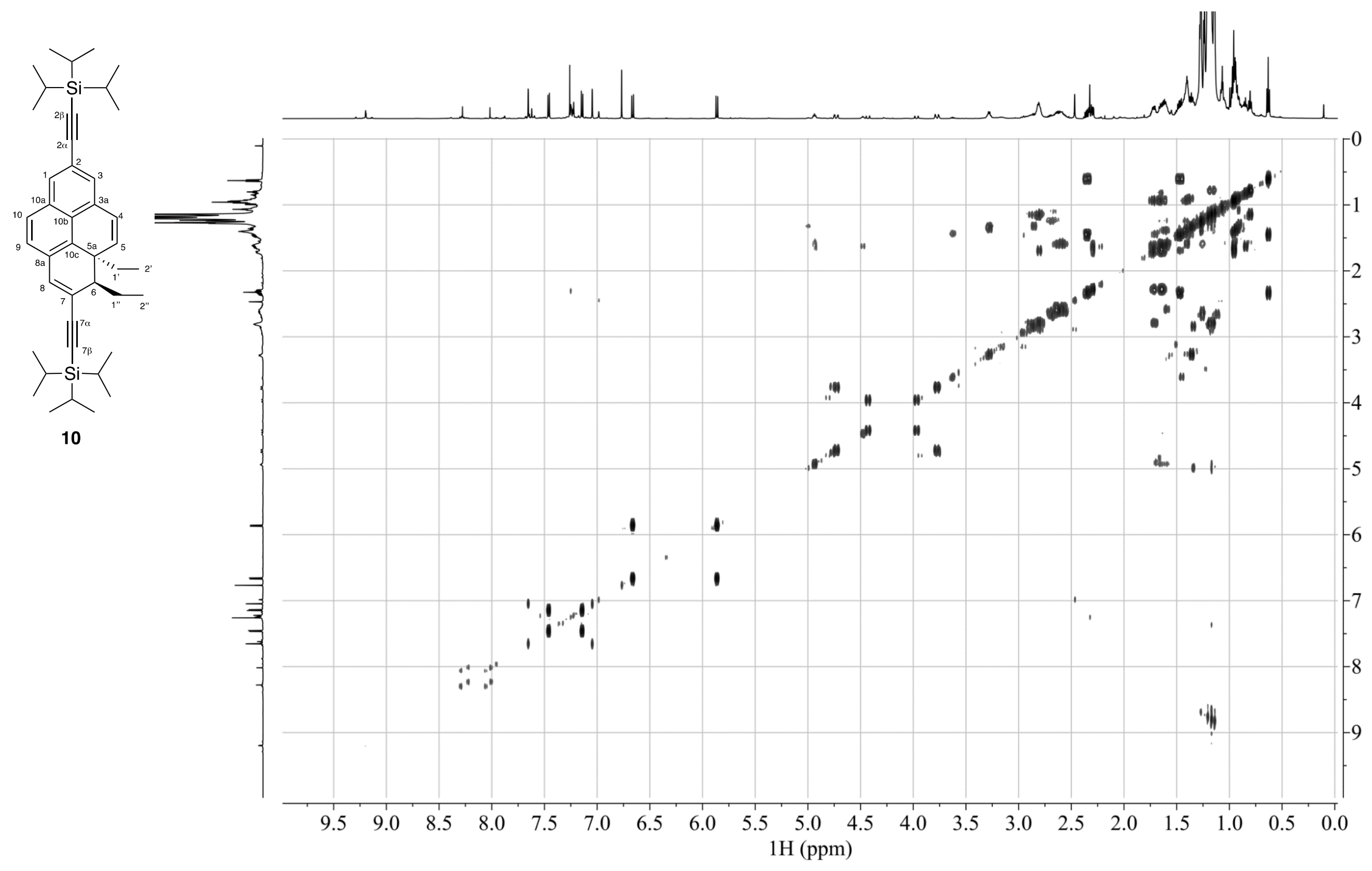

Figure S35. Full COSY NMR spectrum of the mixture obtained from heating 8 to $200^{\circ} \mathrm{C}$, containing mostly 10 . 


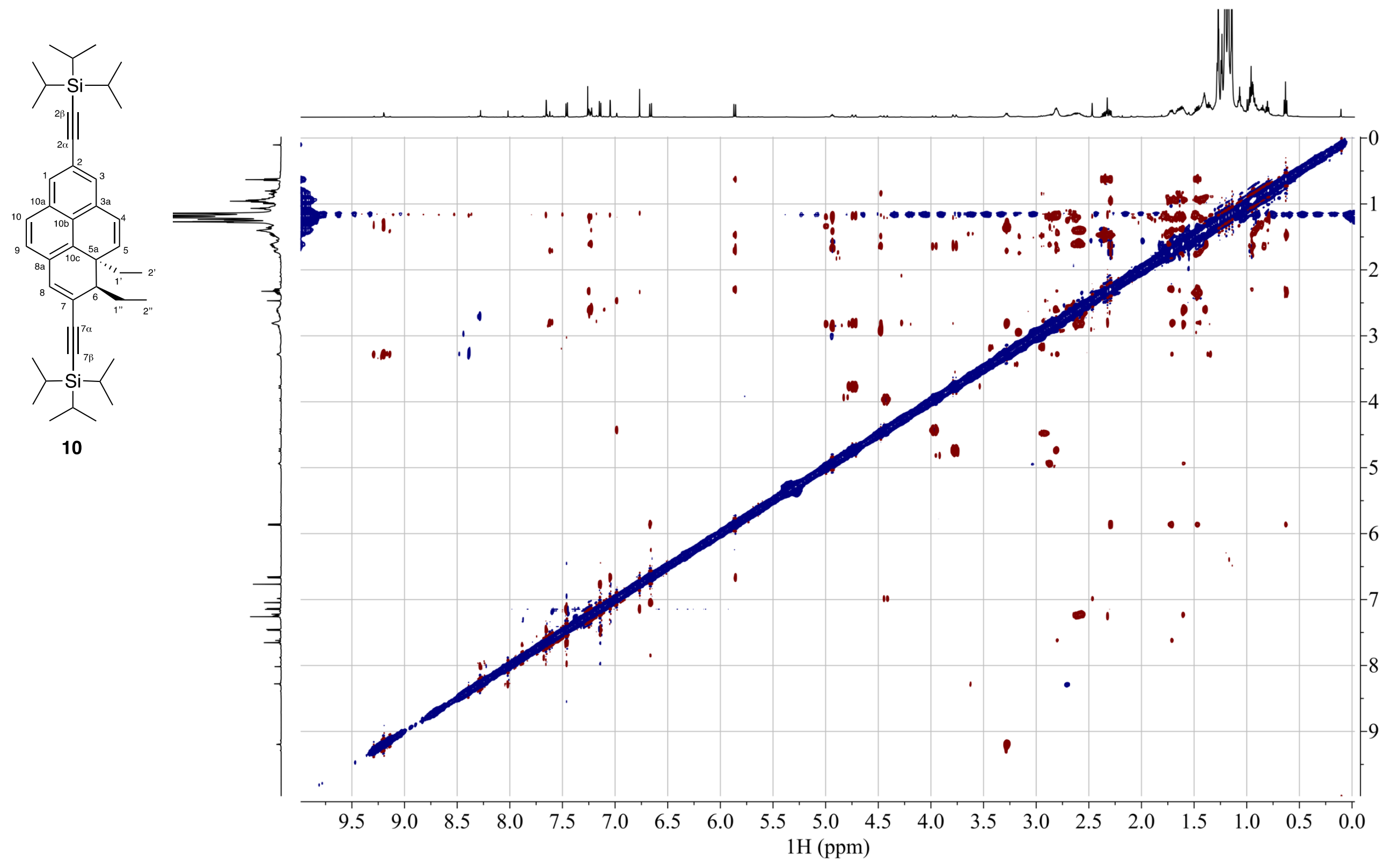

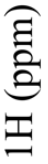

Figure S36. Full NOESY NMR spectrum of the mixture obtained from heating 8 to $200^{\circ} \mathrm{C}$, containing mostly 10 . 


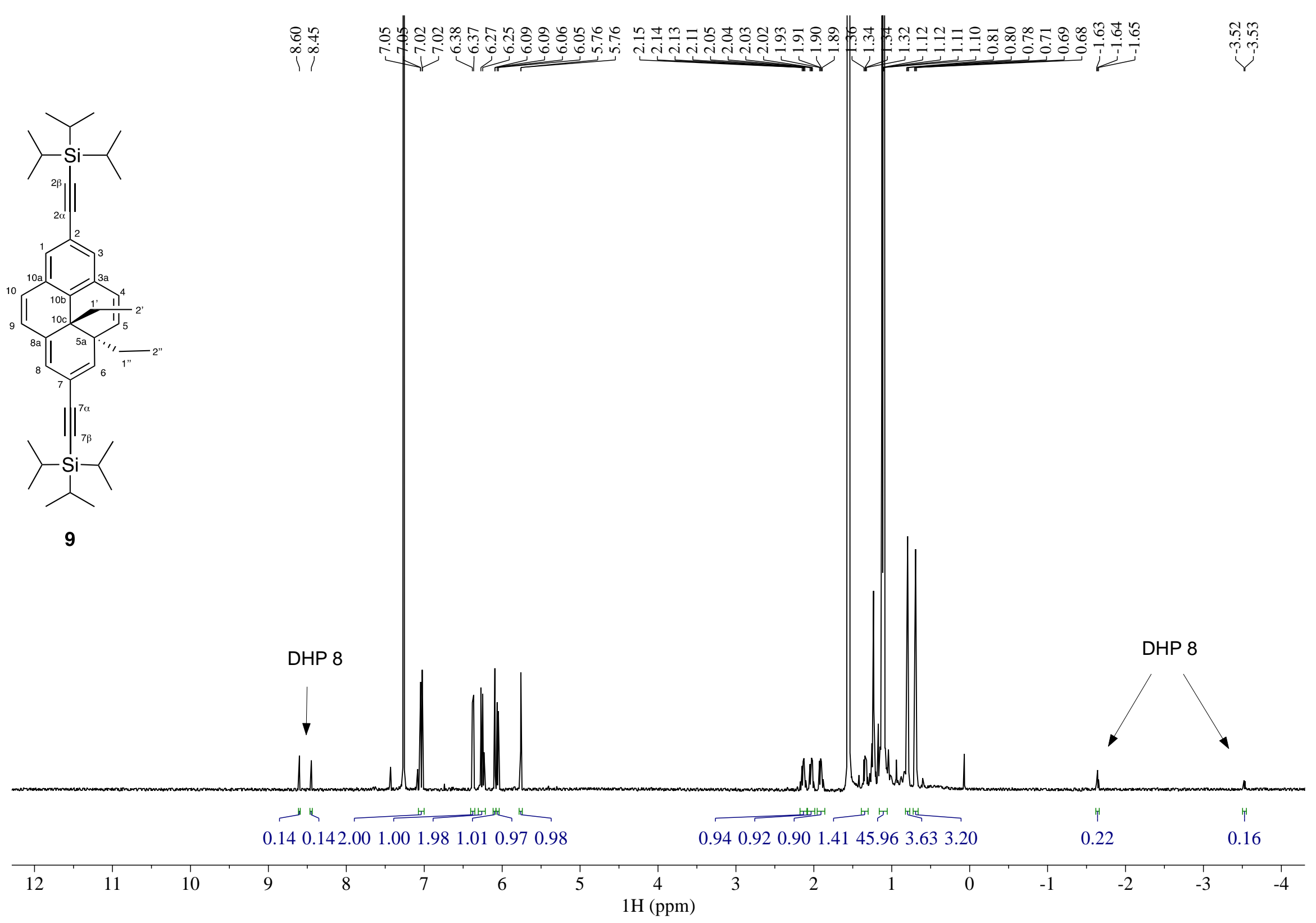

Figure S37. ${ }^{1} \mathrm{H}$ NMR spectrum of $\mathbf{9}$, obtained from heating of crystalline 8. 


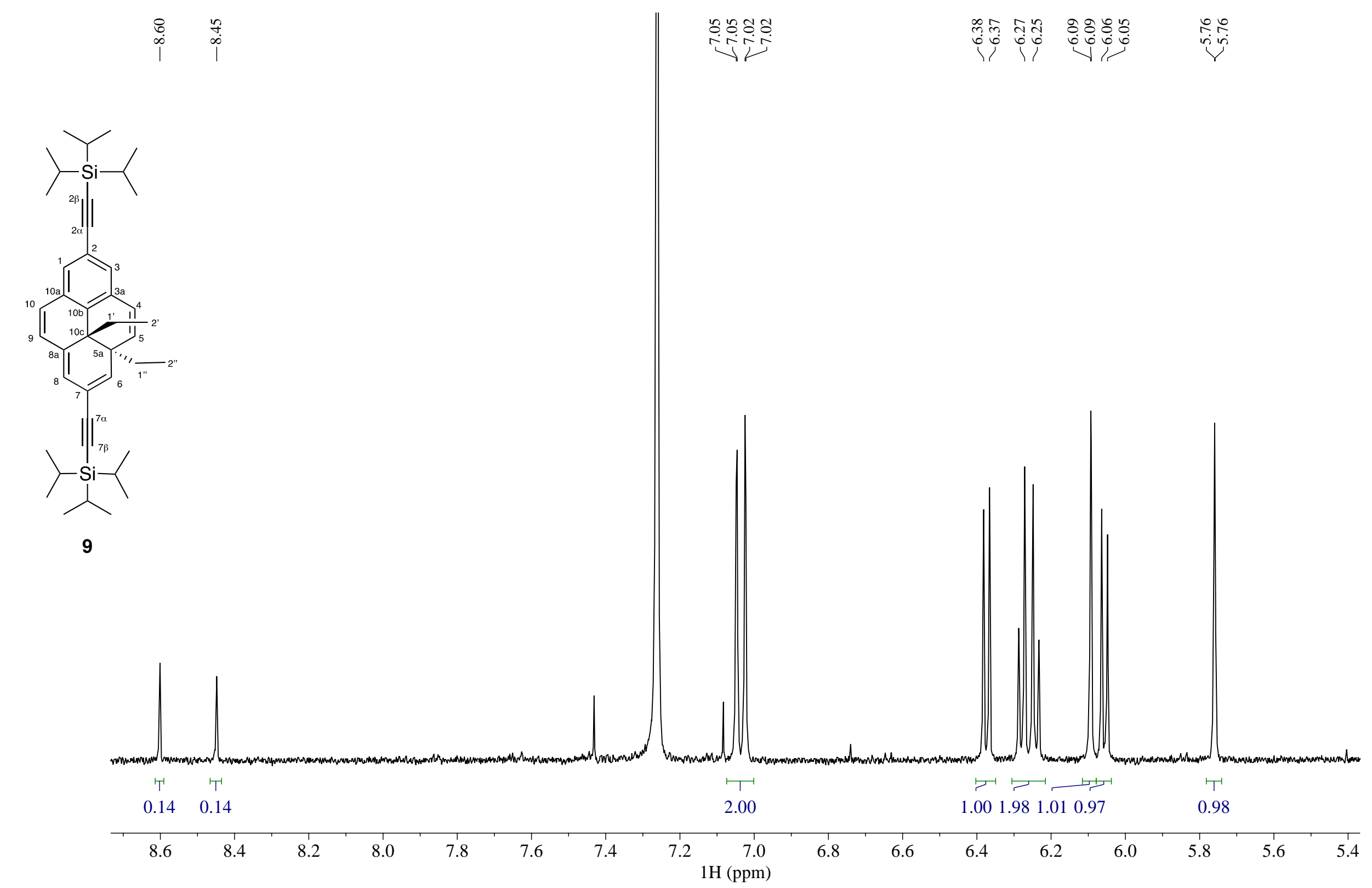

Figure S38. Selected aromatic range of the ${ }^{1} \mathrm{H}$ NMR spectrum of 9, obtained from heating of crystalline 8. 


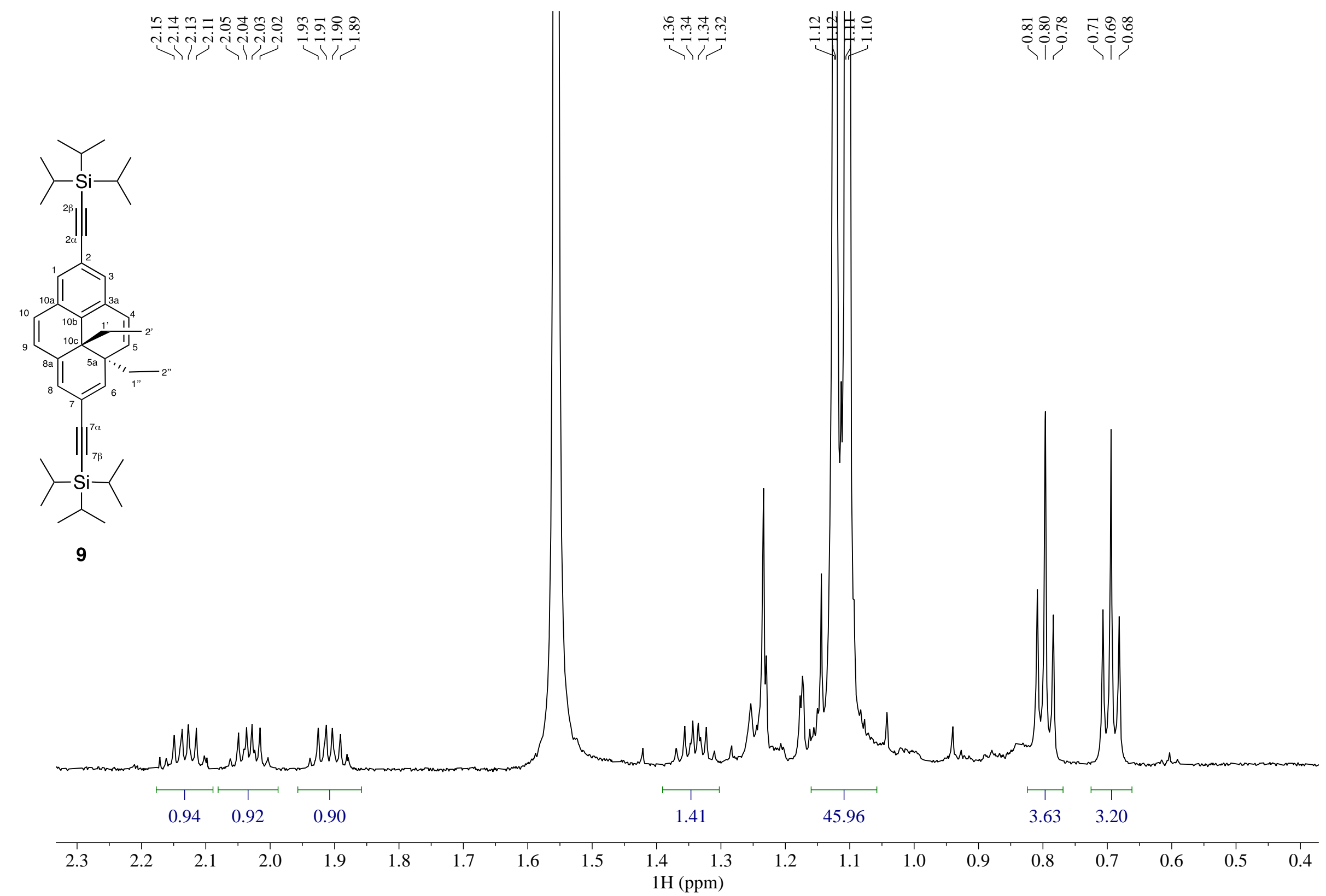

Figure S39. Selected aliphatic range of the ${ }^{1} \mathrm{H}$ NMR spectrum of $\mathbf{9}$, obtained from heating of crystalline 8. 


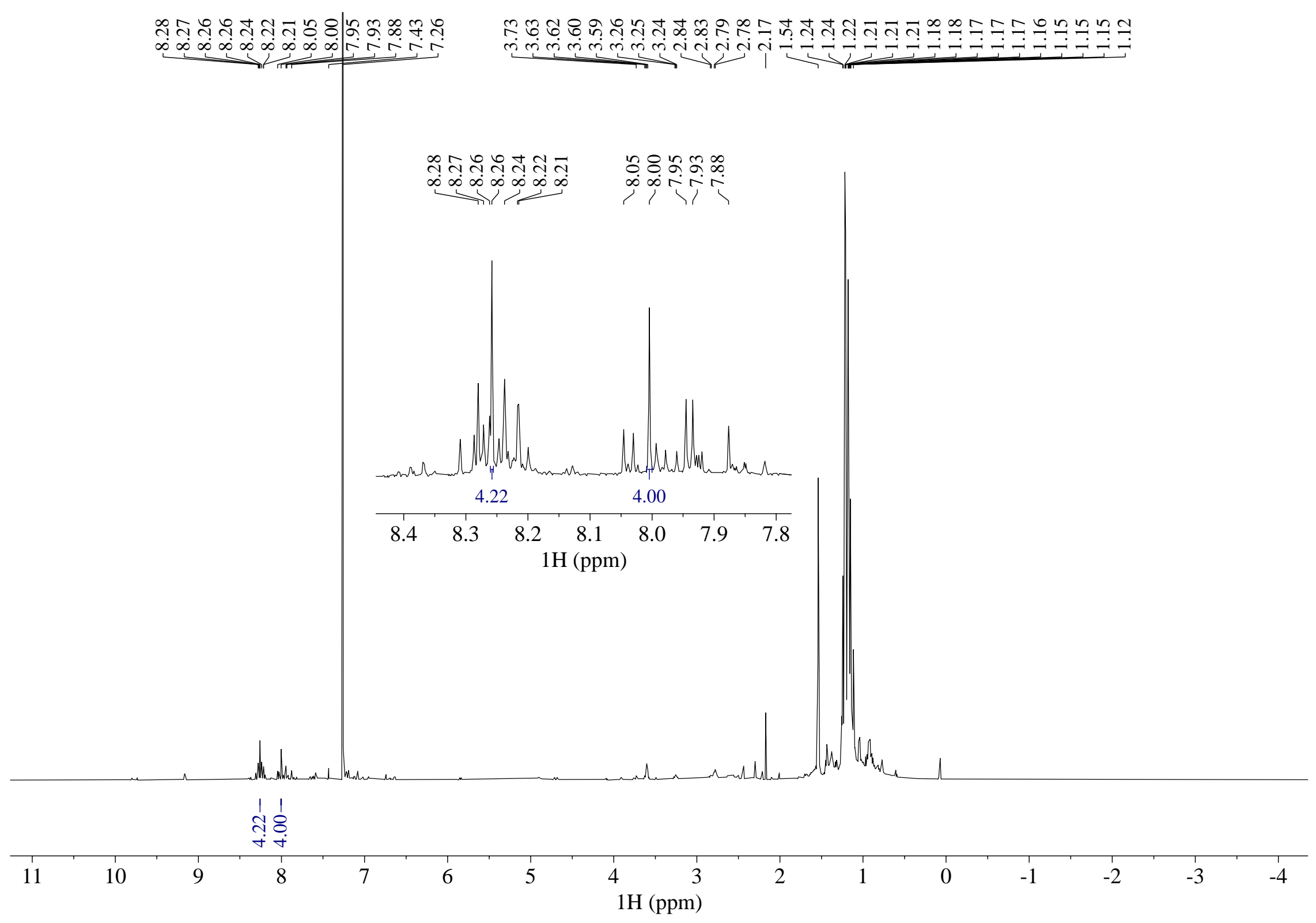

Figure S40. ${ }^{1} \mathrm{H}$ NMR spectrum of 8 heated to $250{ }^{\circ} \mathrm{C}$, containing mostly 12 . 


\section{Computational Details}

Optimized geometries and energies of stationary points and transition states were computed with DFT with the Gaussian 09 program suite, ${ }^{8}$ using the familiar B3LYP functional $\left.\right|^{9,10}$ and $6-31+G^{* 11-16}$ basis sets. The stationary points and transition states were plotted using CYLview ${ }^{17}$.

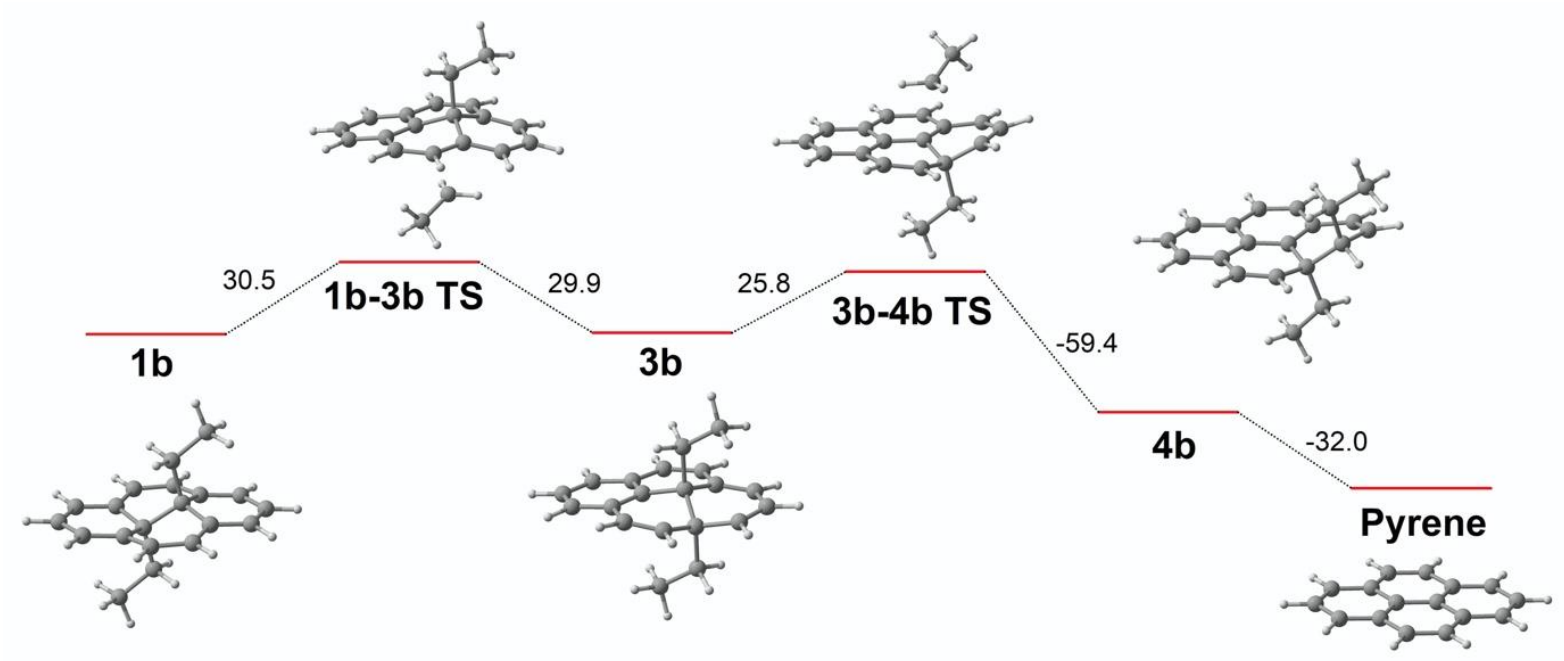

Figure S41. DFT computed Gibbs free energy profile for the transformation of DHP DHP $1 \mathbf{b}$ to pyrene. Calculations were performed at B3LYP/6-31+G* level of theory. Relative energies are reported in $\mathrm{kcal} \mathrm{mol}^{-1}$. 


\section{Ethane}

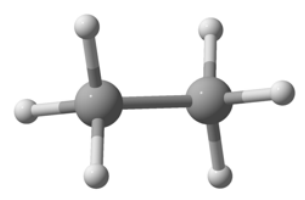

Electronic Energy

Sum of electronic and zero-point Energies

Sum of electronic and thermal Energies $-79.758637$

Sum of electronic and thermal Enthalpies

$-79.755161$

\begin{tabular}{ll} 
Sum of electronic and thermal Free Energies & -79.780062 \\
\hline
\end{tabular}

\begin{tabular}{|c|l|l|l|}
\hline \multicolumn{4}{|c|}{ Cartesian Coordinates / $\AA$} \\
\hline & \multicolumn{1}{|c|}{$\mathrm{X}$} & \multicolumn{1}{c|}{$\mathrm{y}$} & \multicolumn{1}{c|}{$\mathrm{Z}$} \\
\hline $\mathrm{C}$ & 0.000000 & 0.000000 & 0.766226 \\
\hline $\mathrm{C}$ & 0.000000 & 0.000000 & -0.766226 \\
\hline $\mathrm{H}$ & 0.000000 & 1.021673 & 1.165158 \\
\hline $\mathrm{H}$ & 0.884795 & -0.510837 & 1.165158 \\
\hline $\mathrm{H}$ & -0.884795 & -0.510837 & 1.165158 \\
\hline $\mathrm{H}$ & 0.884795 & 0.510837 & -1.165158 \\
\hline $\mathrm{H}$ & -0.884795 & 0.510837 & -1.165158 \\
\hline $\mathrm{H}$ & 0.000000 & -1.021673 & -1.165158 \\
\hline
\end{tabular}

\section{Butane}

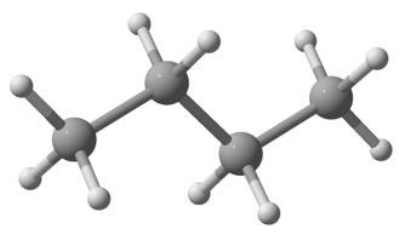

\begin{tabular}{|l|l|}
\hline Electronic Energy & -158.4632083 \\
\hline Sum of electronic and zero-point Energies & -158.330909 \\
\hline Sum of electronic and thermal Energies & -158.325124 \\
\hline Sum of electronic and thermal Enthalpies & -158.324180 \\
\hline Sum of electronic and thermal Free Energies & -158.358298 \\
\hline
\end{tabular}

\begin{tabular}{|c|l|l|l|}
\hline \multicolumn{4}{|c|}{ Cartesian Coordinates / $\AA$} \\
\hline & \multicolumn{1}{|c|}{$\mathrm{X}$} & \multicolumn{1}{|c|}{$\mathrm{y}$} & \multicolumn{1}{c|}{$\mathrm{z}$} \\
\hline $\mathrm{C}$ & 0.704786 & 1.837140 & 0.000000 \\
\hline $\mathrm{C}$ & 0.704786 & 0.303809 & 0.000000 \\
\hline H & 0.190747 & 2.233278 & -0.885417 \\
\hline H & 1.725332 & 2.238888 & 0.000000 \\
\hline H & 0.190747 & 2.233278 & 0.885417 \\
\hline C & -0.704786 & -0.303809 & 0.000000 \\
\hline H & 1.255485 & -0.062639 & 0.878970 \\
\hline H & 1.255485 & -0.062639 & -0.878970 \\
\hline C & -0.704786 & -1.837140 & 0.000000 \\
\hline H & -1.255485 & 0.062639 & -0.878970 \\
\hline H & -1.255485 & 0.062639 & 0.878970 \\
\hline H & -0.190747 & -2.233278 & -0.885417 \\
\hline H & -1.725332 & -2.238888 & 0.000000 \\
\hline H & -0.190747 & -2.233278 & 0.885417 \\
\hline \multicolumn{4}{|c}{}
\end{tabular}




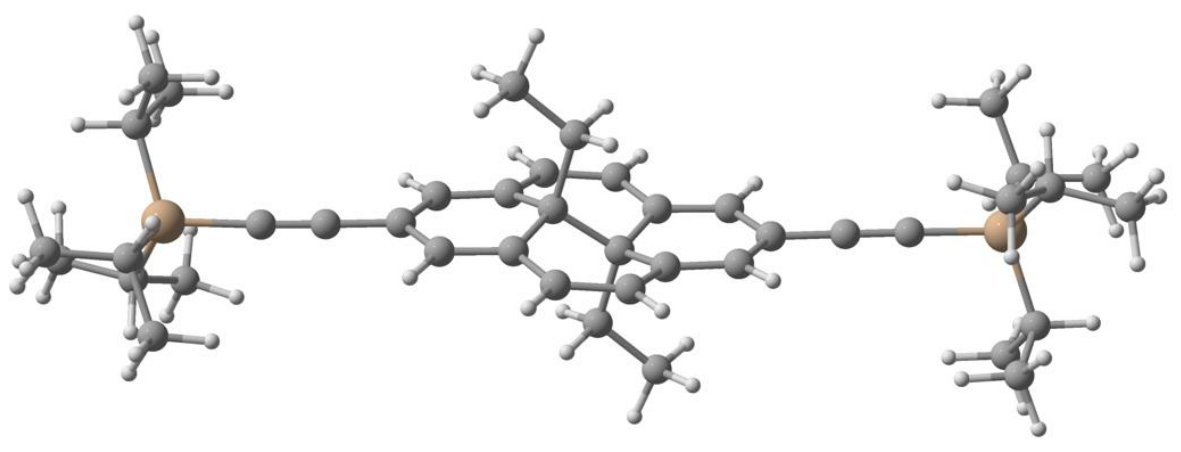

\begin{tabular}{|l|l|l|l|}
\hline \multicolumn{4}{|c|}{ Cartesian Coordinates $/ \AA$} \\
\hline & \multicolumn{1}{|c|}{$\mathrm{X}$} & \multicolumn{1}{c|}{$\mathrm{y}$} & $\mathrm{Z}$ \\
\hline $\mathrm{C}$ & -3.528051 & 0.083566 & -0.076411 \\
\hline $\mathrm{C}$ & -2.809223 & 1.294761 & -0.228043 \\
\hline $\mathrm{H}$ & -3.364601 & 2.230009 & -0.244413 \\
\hline $\mathrm{C}$ & -1.422036 & 1.318217 & -0.288149 \\
\hline $\mathrm{C}$ & -0.666396 & 2.507034 & -0.327387 \\
\hline $\mathrm{H}$ & -1.190495 & 3.456298 & -0.422956 \\
\hline $\mathrm{C}$ & -0.653583 & 0.003087 & -0.407291 \\
\hline $\mathrm{C}$ & -0.300484 & -0.195139 & -1.942486 \\
\hline $\mathrm{H}$ & 0.329309 & 0.645082 & -2.251315 \\
\hline $\mathrm{H}$ & 0.312569 & -1.097658 & -2.030594 \\
\hline $\mathrm{C}$ & -1.479982 & -0.307648 & -2.915222 \\
\hline $\mathrm{H}$ & -2.101836 & 0.593570 & -2.918166 \\
\hline $\mathrm{H}$ & -2.122490 & -1.164564 & -2.688228 \\
\hline $\mathrm{C}$ & -1.455416 & -1.220043 & 0.033027 \\
\hline $\mathrm{C}$ & -0.731830 & -2.401492 & 0.291950 \\
\hline $\mathrm{H}$ & -1.281337 & -3.330502 & 0.432939 \\
\hline $\mathrm{C}$ & -2.840695 & -1.145609 & 0.081861 \\
\hline $\mathrm{H}$ & -3.420240 & -2.040164 & 0.298915 \\
\hline $\mathrm{C}$ & -4.950850 & 0.102313 & -0.020270 \\
\hline $\mathrm{C}$ & -6.175169 & 0.100467 & 0.021528 \\
\hline $\mathrm{Si}$ & -8.021831 & 0.054318 & 0.032181 \\
\hline $\mathrm{C}$ & -8.575334 & -1.095744 & -1.400508 \\
\hline $\mathrm{H}$ & -9.672886 & -1.158453 & -1.329454 \\
\hline $\mathrm{C}$ & -8.227235 & -0.509600 & -2.784131 \\
\hline $\mathrm{H}$ & -7.142653 & -0.392824 & -2.904860 \\
\hline $\mathrm{H}$ & -8.687732 & 0.470998 & -2.952236 \\
\hline $\mathrm{H}$ & -8.576113 & -1.176581 & -3.585307 \\
\hline $\mathrm{C}$ & -8.016378 & -2.527026 & -1.273680 \\
\hline $\mathrm{H}$ & -8.368216 & -3.154861 & -2.104727 \\
\hline $\mathrm{H}$ & -8.324265 & -3.015422 & -0.342216 \\
\hline $\mathrm{H}$ & -6.919729 & -2.527580 & -1.302588 \\
\hline $\mathrm{C}$ & -8.615786 & -0.572678 & 1.751947 \\
\hline $\mathrm{H}$ & -8.626718 & 0.328946 & 2.384687 \\
\hline $\mathrm{C}$ & -7.661609 & -1.580378 & 2.423804 \\
\hline $\mathrm{H}$ & -8.021546 & -1.837609 & 3.430330 \\
\hline $\mathrm{H}$ & -6.647301 & -1.179452 & 2.521390 \\
\hline $\mathrm{H}$ & -7.592306 & -2.515987 & 1.855040 \\
\hline $\mathrm{C}$ & -10.055527 & -1.129250 & 1.721405 \\
\hline $\mathrm{H}$ & -10.119430 & -2.049626 & 1.127180 \\
\hline $\mathrm{H}$ & -10.776039 & -0.416745 & 1.303153 \\
\hline $\mathrm{H}$ & -10.393730 & -1.377229 & 2.737369 \\
\hline $\mathrm{C}$ & -8.613171 & 1.851653 & -0.292853 \\
\hline $\mathrm{H}$ & -8.138255 & 2.127256 & -1.247263 \\
\hline & -10.138714 & 1.980875 & -0.476543 \\
\hline
\end{tabular}

\begin{tabular}{|l|l|l|l|}
\hline $\mathrm{H}$ & -10.526065 & 1.314973 & -1.257362 \\
\hline $\mathrm{H}$ & -10.409621 & 3.008175 & -0.758383 \\
\hline $\mathrm{C}$ & -8.109141 & 2.847116 & 0.770755 \\
\hline $\mathrm{H}$ & -8.372900 & 3.877850 & 0.494127 \\
\hline $\mathrm{H}$ & -7.020507 & 2.803118 & 0.890828 \\
\hline $\mathrm{H}$ & -8.560938 & 2.652891 & 1.752441 \\
\hline $\mathrm{C}$ & 3.524141 & 0.010719 & 0.095832 \\
\hline $\mathrm{C}$ & 2.804184 & -1.199880 & 0.251116 \\
\hline $\mathrm{H}$ & 3.359013 & -2.135483 & 0.264991 \\
\hline $\mathrm{C}$ & 1.417801 & -1.222526 & 0.315818 \\
\hline $\mathrm{C}$ & 0.662250 & -2.411665 & 0.356746 \\
\hline $\mathrm{H}$ & 1.186624 & -3.360729 & 0.452702 \\
\hline $\mathrm{C}$ & 0.650138 & 0.092876 & 0.435335 \\
\hline $\mathrm{C}$ & 0.297746 & 0.291215 & 1.970505 \\
\hline $\mathrm{H}$ & -0.332085 & -0.548800 & 2.279849 \\
\hline $\mathrm{H}$ & -0.314916 & 1.193954 & 2.058992 \\
\hline $\mathrm{C}$ & 1.478245 & 0.403336 & 2.942074 \\
\hline $\mathrm{H}$ & 2.100013 & -0.497961 & 2.943974 \\
\hline $\mathrm{H}$ & 2.120600 & 1.260238 & 2.714549 \\
\hline $\mathrm{C}$ & 1.452300 & 1.315817 & -0.005502 \\
\hline $\mathrm{C}$ & 0.728205 & 2.496957 & -0.263047 \\
\hline $\mathrm{H}$ & 1.277200 & 3.426206 & -0.404534 \\
\hline $\mathrm{C}$ & 2.837982 & 1.240572 & -0.058275 \\
\hline $\mathrm{H}$ & 3.417274 & 2.134969 & -0.276754 \\
\hline $\mathrm{C}$ & 4.946251 & -0.019176 & 0.028057 \\
\hline $\mathrm{C}$ & 6.169814 & -0.045905 & -0.025299 \\
\hline $\mathrm{Si}$ & 8.015465 & -0.103258 & -0.064939 \\
\hline $\mathrm{C}$ & 8.660263 & 0.697496 & 1.554102 \\
\hline $\mathrm{H}$ & 9.759295 & 0.690419 & 1.475191 \\
\hline $\mathrm{C}$ & 8.273834 & -0.121502 & 2.802592 \\
\hline $\mathrm{H}$ & 7.183924 & -0.177682 & 2.918739 \\
\hline $\mathrm{H}$ & 8.657894 & -1.147741 & 2.765881 \\
\hline $\mathrm{H}$ & 8.676683 & 0.346424 & 3.712096 \\
\hline $\mathrm{C}$ & 8.212591 & 2.163641 & 1.719771 \\
\hline $\mathrm{H}$ & 8.623714 & 2.591899 & 2.645070 \\
\hline $\mathrm{H}$ & 8.544539 & 2.798092 & 0.890123 \\
\hline $\mathrm{H}$ & 7.119771 & 2.240228 & 1.779918 \\
\hline $\mathrm{C}$ & 8.634085 & 0.814706 & -1.638435 \\
\hline $\mathrm{H}$ & 8.584386 & 0.057269 & -2.436626 \\
\hline $\mathrm{C}$ & 7.742336 & 1.990779 & -2.085982 \\
\hline $\mathrm{H}$ & 8.112555 & 2.413956 & -3.030778 \\
\hline $\mathrm{H}$ & 6.704066 & 1.679385 & -2.241310 \\
\hline $\mathrm{H}$ & 7.736255 & 2.802290 & -1.347688 \\
\hline $\mathrm{H}$ & 10.106029 & 1.267701 & -1.526005 \\
\hline & 10.453572 & 0.050720 & -0.767153 \\
\hline & & 1.686481 & -2.480921 \\
\hline
\end{tabular}




\begin{tabular}{|l|l|l|l|}
\hline C & 8.491353 & -1.962288 & -0.116103 \\
\hline H & 7.997879 & -2.392988 & 0.769085 \\
\hline C & 10.004963 & -2.221826 & 0.022073 \\
\hline H & 10.557103 & -1.854366 & -0.852235 \\
\hline H & 10.434536 & -1.744168 & 0.911111 \\
\hline H & 10.208212 & -3.299342 & 0.098880 \\
\hline
\end{tabular}

\begin{tabular}{|l|l|l|l|}
\hline C & 7.926134 & -2.691379 & -1.350911 \\
\hline$H$ & 8.118628 & -3.771808 & -1.286417 \\
\hline$H$ & 6.843422 & -2.551613 & -1.449923 \\
\hline$H$ & 8.394496 & -2.337103 & -2.278593 \\
\hline$H$ & 1.093908 & 0.540521 & 3.960173 \\
\hline$H$ & -1.094401 & -0.445092 & -3.932822 \\
\hline
\end{tabular}

\begin{tabular}{|l|l|}
\hline Electronic Energy & -2215.583214 \\
\hline Sum of electronic and zero-point Energies & -2214.674101 \\
\hline Sum of electronic and thermal Energies & -2214.621527 \\
\hline Sum of electronic and thermal Enthalpies & -2214.620583 \\
\hline Sum of electronic and thermal Free Energies & -2214.763966 \\
\hline
\end{tabular}

\section{8-9 TS}

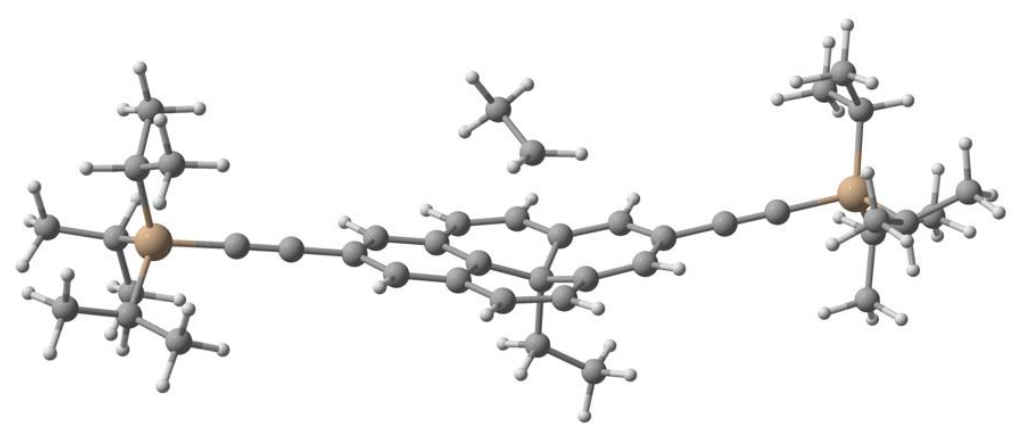

\begin{tabular}{|c|c|c|c|}
\hline \multicolumn{4}{|c|}{ Cartesian Coordinates $/ \AA$} \\
\hline & $\mathrm{X}$ & $\mathrm{y}$ & $\mathrm{Z}$ \\
\hline $\mathrm{C}$ & 3.446484 & -0.415862 & 0.006193 \\
\hline $\mathrm{C}$ & 2.727214 & -0.478007 & 1.239424 \\
\hline $\mathrm{H}$ & 3.258333 & -0.246323 & 2.160175 \\
\hline $\mathrm{C}$ & 1.371837 & -0.723671 & 1.277627 \\
\hline $\mathrm{C}$ & 0.611491 & -0.610906 & 2.486885 \\
\hline $\mathrm{H}$ & 1.148855 & -0.493822 & 3.426412 \\
\hline $\mathrm{C}$ & 0.652433 & -1.215943 & 0.028961 \\
\hline $\mathrm{C}$ & 0.587793 & -2.804362 & 0.058062 \\
\hline $\mathrm{H}$ & 0.019008 & -3.081866 & 0.954321 \\
\hline $\mathrm{H}$ & -0.013249 & -3.114005 & -0.805393 \\
\hline $\mathrm{C}$ & 1.914559 & -3.571767 & 0.046411 \\
\hline $\mathrm{H}$ & 2.544418 & -3.321467 & 0.906225 \\
\hline $\mathrm{H}$ & 2.491722 & -3.379370 & -0.863819 \\
\hline $\mathrm{C}$ & 1.355258 & -0.732975 & -1.227954 \\
\hline $\mathrm{C}$ & 0.620711 & -0.762427 & -2.449204 \\
\hline $\mathrm{H}$ & 1.168475 & -0.693467 & -3.387710 \\
\hline $\mathrm{C}$ & 2.738521 & -0.505010 & -1.201079 \\
\hline $\mathrm{C}$ & 4.848153 & -0.166957 & 0.012107 \\
\hline $\mathrm{C}$ & 6.055649 & 0.039822 & 0.030481 \\
\hline $\mathrm{Si}$ & 7.875052 & 0.353388 & 0.015602 \\
\hline $\mathrm{C}$ & 8.173073 & 2.024898 & -0.877704 \\
\hline $\mathrm{H}$ & 9.261946 & 2.190641 & -0.853116 \\
\hline $\mathrm{C}$ & 7.741159 & 1.974313 & -2.357458 \\
\hline $\mathrm{H}$ & 6.665907 & 1.774974 & -2.449623 \\
\hline $\mathrm{H}$ & 8.272502 & 1.200490 & -2.923976 \\
\hline $\mathrm{H}$ & 7.939768 & 2.935987 & -2.851778 \\
\hline $\mathrm{C}$ & 7.500964 & 3.217635 & -0.168340 \\
\hline $\mathrm{H}$ & 7.704746 & 4.153809 & -0.707760 \\
\hline
\end{tabular}

\begin{tabular}{|c|c|c|c|}
\hline $\mathrm{H}$ & 7.859202 & 3.349055 & 0.858961 \\
\hline $\mathrm{H}$ & 6.411704 & 3.092711 & -0.126971 \\
\hline $\mathrm{C}$ & 8.512112 & 0.355262 & 1.830148 \\
\hline $\mathrm{H}$ & 8.664028 & -0.708739 & 2.071101 \\
\hline $\mathrm{C}$ & 7.503020 & 0.905338 & 2.858212 \\
\hline $\mathrm{H}$ & 7.899322 & 0.800966 & 3.878482 \\
\hline $\mathrm{H}$ & 6.546204 & 0.374754 & 2.813391 \\
\hline $\mathrm{H}$ & 7.296166 & 1.970575 & 2.697920 \\
\hline $\mathrm{C}$ & 9.877219 & 1.060062 & 1.983720 \\
\hline $\mathrm{H}$ & 9.800353 & 2.135402 & 1.779258 \\
\hline $\mathrm{H}$ & 10.642180 & 0.651842 & 1.312999 \\
\hline $\mathrm{H}$ & 10.252857 & 0.952980 & 3.011081 \\
\hline $\mathrm{C}$ & 8.656411 & -1.079661 & -0.997113 \\
\hline $\mathrm{H}$ & 8.119369 & -1.054715 & -1.958042 \\
\hline $\mathrm{C}$ & 10.157395 & -0.893387 & -1.297969 \\
\hline $\mathrm{H}$ & 10.761598 & -0.951760 & -0.383679 \\
\hline $\mathrm{H}$ & 10.375431 & 0.067716 & -1.779445 \\
\hline $\mathrm{H}$ & 10.518043 & -1.685045 & -1.969968 \\
\hline $\mathrm{C}$ & 8.398056 & -2.463590 & -0.369124 \\
\hline $\mathrm{H}$ & 8.753813 & -3.264156 & -1.033313 \\
\hline $\mathrm{H}$ & 7.332063 & -2.636424 & -0.181797 \\
\hline $\mathrm{H}$ & 8.928915 & -2.578680 & 0.585091 \\
\hline $\mathrm{C}$ & -3.582370 & -0.307166 & -0.013114 \\
\hline $\mathrm{C}$ & -2.880168 & -0.477887 & -1.217854 \\
\hline $\mathrm{H}$ & -3.422398 & -0.441310 & -2.159141 \\
\hline $\mathrm{C}$ & -1.492017 & -0.692278 & -1.225458 \\
\hline $\mathrm{C}$ & -0.751263 & -0.789641 & -2.459160 \\
\hline $\mathrm{H}$ & -1.298293 & -0.801807 & -3.398682 \\
\hline $\mathrm{C}$ & -0.780821 & -0.720606 & 0.006284 \\
\hline $\mathrm{C}$ & 0.453334 & 1.739568 & -0.253791 \\
\hline & & & \\
\hline
\end{tabular}




\begin{tabular}{|c|c|c|c|}
\hline C & -0.064284 & 2.319270 & -1.514837 \\
\hline H & -0.703485 & 1.608258 & -2.074592 \\
\hline H & -0.703533 & 3.194581 & -1.321581 \\
\hline C & -1.492268 & -0.565661 & 1.231834 \\
\hline C & -0.754933 & -0.575002 & 2.473654 \\
\hline$H$ & -1.309620 & -0.466134 & 3.402747 \\
\hline C & -2.874723 & -0.343572 & 1.204355 \\
\hline$H$ & -3.415405 & -0.203860 & 2.136647 \\
\hline C & -4.997013 & -0.098036 & -0.017042 \\
\hline C & -6.208055 & 0.073081 & -0.008370 \\
\hline Si & -8.041573 & 0.299537 & -0.008700 \\
\hline C & -8.410655 & 2.166558 & 0.227063 \\
\hline H & -9.507689 & 2.252077 & 0.283530 \\
\hline C & -7.934242 & 3.008638 & -0.974389 \\
\hline H & -6.847196 & 2.932652 & -1.105020 \\
\hline H & -8.404631 & 2.700409 & -1.915581 \\
\hline H & -8.172706 & 4.070983 & -0.822167 \\
\hline C & -7.829504 & 2.733428 & 1.538061 \\
\hline$H$ & -8.074652 & 3.800220 & 1.640922 \\
\hline$H$ & -8.221116 & 2.221618 & 2.424414 \\
\hline$H$ & -6.736129 & 2.643957 & 1.558465 \\
\hline C & -8.786877 & -0.783029 & 1.397168 \\
\hline$H$ & -8.877844 & -1.786992 & 0.953276 \\
\hline
\end{tabular}

\begin{tabular}{|c|c|c|c|}
\hline C & -7.880867 & -0.924486 & 2.636812 \\
\hline$H$ & -8.333485 & -1.611908 & 3.365738 \\
\hline$H$ & -6.891993 & -1.315089 & 2.375599 \\
\hline$H$ & -7.731617 & 0.035789 & 3.145996 \\
\hline$C$ & -10.204796 & -0.335445 & 1.812711 \\
\hline$H$ & -10.192168 & 0.654231 & 2.286565 \\
\hline$H$ & -10.897548 & -0.284817 & 0.964662 \\
\hline$H$ & -10.632320 & -1.037559 & 2.542557 \\
\hline$C$ & -8.648128 & -0.284911 & -1.734530 \\
\hline$H$ & -8.074702 & 0.328706 & -2.446717 \\
\hline C & -10.145449 & -0.021580 & -1.991887 \\
\hline$H$ & -10.778792 & -0.636888 & -1.340422 \\
\hline$H$ & -10.422226 & 1.027308 & -1.829486 \\
\hline$H$ & -10.412574 & -0.273065 & -3.028213 \\
\hline$C$ & -8.297147 & -1.758423 & -2.019294 \\
\hline$H$ & -8.562014 & -2.029598 & -3.051234 \\
\hline$H$ & -7.227383 & -1.956383 & -1.886751 \\
\hline$H$ & -8.846368 & -2.440546 & -1.357172 \\
\hline$H$ & -0.162092 & 1.794540 & 0.637921 \\
\hline$H$ & 1.521813 & 1.706777 & -0.080604 \\
\hline$H$ & 3.265805 & -0.324817 & -2.135393 \\
\hline$H$ & 0.745025 & 2.611045 & -2.192945 \\
\hline$H$ & 1.711359 & -4.649133 & 0.088006 \\
\hline
\end{tabular}

\begin{tabular}{|l|l|}
\hline Electronic Energy & -2215.528890 \\
\hline Sum of electronic and zero-point Energies & -2214.624470 \\
\hline Sum of electronic and thermal Energies & -2214.572048 \\
\hline Sum of electronic and thermal Enthalpies & -2214.571104 \\
\hline Sum of electronic and thermal Free Energies & -2214.713272 \\
\hline
\end{tabular}

Imaginary mode $=116 \mathrm{i} \mathrm{cm}{ }^{-1}$

9

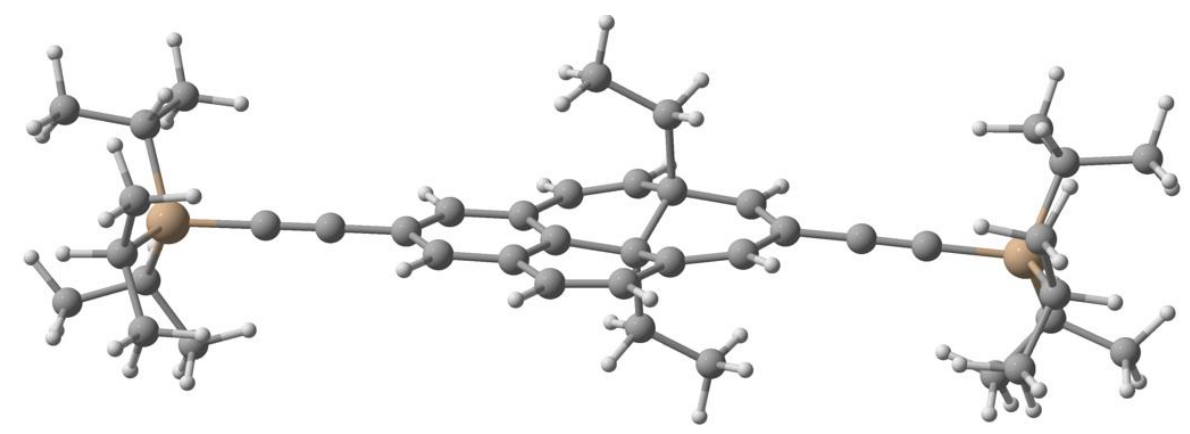

\begin{tabular}{|c|c|c|c|}
\hline \multicolumn{4}{|c|}{ Cartesian Coordinates / $\AA$} \\
\hline & $\mathrm{X}$ & $\mathrm{y}$ & $\mathrm{Z}$ \\
\hline $\mathrm{C}$ & -3.451036 & 0.191188 & -0.220783 \\
\hline $\mathrm{C}$ & -2.721571 & -0.925003 & -0.842674 \\
\hline $\mathrm{H}$ & -3.289172 & -1.646700 & -1.425464 \\
\hline $\mathrm{C}$ & -1.376959 & -1.058611 & -0.690039 \\
\hline $\mathrm{C}$ & -0.603677 & -2.121920 & -1.298858 \\
\hline H & -1.140481 & -2.901204 & -1.836785 \\
\hline $\mathrm{C}$ & -0.661131 & -0.096590 & 0.245641 \\
\hline $\mathrm{C}$ & -0.764119 & -0.708287 & 1.721362 \\
\hline H & -0.240121 & -1.670133 & 1.657092 \\
\hline
\end{tabular}

\begin{tabular}{|l|l|l|l|}
\hline$H$ & -0.156494 & -0.075042 & 2.373833 \\
\hline $\mathrm{C}$ & -2.112424 & -0.950852 & 2.411330 \\
\hline $\mathrm{H}$ & -2.799582 & -1.549059 & 1.805732 \\
\hline $\mathrm{H}$ & -2.620052 & -0.019274 & 2.677746 \\
\hline $\mathrm{C}$ & -1.261536 & 1.333932 & 0.084918 \\
\hline $\mathrm{C}$ & -0.530867 & 2.271514 & 1.022751 \\
\hline $\mathrm{H}$ & -1.073442 & 3.116251 & 1.445386 \\
\hline $\mathrm{C}$ & -2.760759 & 1.247943 & 0.287057 \\
\hline $\mathrm{C}$ & -4.878686 & 0.131529 & -0.166481 \\
\hline $\mathrm{C}$ & -6.098895 & 0.052873 & -0.122459 \\
\hline $\mathrm{Si}$ & -7.942314 & -0.043638 & -0.053524 \\
\hline
\end{tabular}




\begin{tabular}{|l|l|l|l|}
\hline $\mathrm{C}$ & -8.476911 & -1.654035 & -0.944629 \\
\hline $\mathrm{H}$ & -9.572549 & -1.706546 & -0.840786 \\
\hline $\mathrm{C}$ & -8.151008 & -1.621069 & -2.451955 \\
\hline $\mathrm{H}$ & -7.070671 & -1.531495 & -2.623498 \\
\hline $\mathrm{H}$ & -8.638999 & -0.785735 & -2.967672 \\
\hline $\mathrm{H}$ & -8.484953 & -2.547579 & -2.940417 \\
\hline $\mathrm{C}$ & -7.884657 & -2.922971 & -0.299032 \\
\hline $\mathrm{H}$ & -8.222893 & -3.822949 & -0.832353 \\
\hline $\mathrm{H}$ & -8.180123 & -3.034768 & 0.750310 \\
\hline $\mathrm{H}$ & -6.788160 & -2.911579 & -0.334515 \\
\hline $\mathrm{C}$ & -8.494899 & -0.001726 & 1.789543 \\
\hline $\mathrm{H}$ & -8.534847 & 1.070208 & 2.040394 \\
\hline $\mathrm{C}$ & -7.496685 & -0.654160 & 2.767048 \\
\hline $\mathrm{H}$ & -7.834217 & -0.522652 & 3.805159 \\
\hline $\mathrm{H}$ & -6.495869 & -0.218902 & 2.680038 \\
\hline $\mathrm{H}$ & -7.401044 & -1.732747 & 2.591182 \\
\hline $\mathrm{C}$ & -9.911923 & -0.576389 & 2.004063 \\
\hline $\mathrm{H}$ & -9.943950 & -1.654049 & 1.799555 \\
\hline $\mathrm{H}$ & -10.664719 & -0.098480 & 1.366516 \\
\hline $\mathrm{H}$ & -10.230403 & -0.436401 & 3.046689 \\
\hline $\mathrm{C}$ & -8.598760 & 1.488946 & -1.006462 \\
\hline $\mathrm{H}$ & -8.150352 & 1.398324 & -2.008051 \\
\hline $\mathrm{C}$ & -10.130788 & 1.506989 & -1.181943 \\
\hline $\mathrm{H}$ & -10.644927 & 1.635828 & -0.220964 \\
\hline $\mathrm{H}$ & -10.512589 & 0.587341 & -1.642145 \\
\hline $\mathrm{H}$ & -10.437230 & 2.345356 & -1.823481 \\
\hline $\mathrm{C}$ & -8.106201 & 2.820933 & -0.407306 \\
\hline $\mathrm{H}$ & -8.411030 & 3.667386 & -1.039106 \\
\hline $\mathrm{H}$ & -7.014279 & 2.849776 & -0.316918 \\
\hline $\mathrm{H}$ & -8.529684 & 2.996689 & 0.590525 \\
\hline $\mathrm{C}$ & 3.653811 & -0.029622 & -0.025369 \\
\hline $\mathrm{C}$ & 2.950828 & 1.018005 & 0.602112 \\
\hline $\mathrm{H}$ & 3.508232 & 1.831300 & 1.059401 \\
\hline $\mathrm{C}$ & 1.551083 & 1.025160 & 0.632934 \\
\hline $\mathrm{C}$ & 0.789463 & 2.126747 & 1.242312 \\
\hline $\mathrm{H}$ & 1.332558 & 2.843620 & 1.855433 \\
\hline $\mathrm{C}$ & 0.843387 & -0.038821 & 0.040120 \\
\hline $\mathrm{C}$ & -1.160317 & 1.949951 & -1.386249 \\
\hline $\mathrm{C}$ & 0.198974 & 2.248641 & -2.031165 \\
\hline $\mathrm{H}$ & 0.828467 & 2.890257 & -1.406937 \\
\hline $\mathrm{H}$ & 0.761072 & 1.338973 & -2.260144 \\
\hline $\mathrm{C}$ & 1.526760 & -1.086593 & -0.600226 \\
\hline $\mathrm{C}$ & 0.752006 & -2.147513 & -1.241698 \\
\hline & & & \\
\hline
\end{tabular}

\begin{tabular}{|l|l|l|l|}
\hline $\mathrm{H}$ & 1.301136 & -2.955889 & -1.719569 \\
\hline $\mathrm{C}$ & 2.930048 & -1.070969 & -0.633421 \\
\hline $\mathrm{H}$ & 3.468864 & -1.875066 & -1.127659 \\
\hline $\mathrm{C}$ & 5.084001 & -0.033058 & -0.038572 \\
\hline $\mathrm{C}$ & 6.307081 & -0.035299 & -0.034529 \\
\hline $\mathrm{Si}$ & 8.154515 & -0.039376 & -0.017670 \\
\hline $\mathrm{C}$ & 8.743690 & -1.612742 & -0.939760 \\
\hline $\mathrm{H}$ & 9.842919 & -1.612530 & -0.863752 \\
\hline $\mathrm{C}$ & 8.377693 & -1.579505 & -2.437888 \\
\hline $\mathrm{H}$ & 7.290289 & -1.539161 & -2.581179 \\
\hline $\mathrm{H}$ & 8.812609 & -0.716805 & -2.955869 \\
\hline $\mathrm{H}$ & 8.742069 & -2.484028 & -2.945372 \\
\hline $\mathrm{C}$ & 8.231047 & -2.916321 & -0.294920 \\
\hline $\mathrm{H}$ & 8.598712 & -3.792416 & -0.848127 \\
\hline $\mathrm{H}$ & 8.558889 & -3.025492 & 0.744990 \\
\hline $\mathrm{H}$ & 7.134710 & -2.958529 & -0.302127 \\
\hline $\mathrm{C}$ & 8.748126 & 0.014228 & 1.811897 \\
\hline $\mathrm{H}$ & 8.722901 & 1.082989 & 2.077942 \\
\hline $\mathrm{C}$ & 7.819342 & -0.716146 & 2.802904 \\
\hline $\mathrm{H}$ & 8.173459 & -0.576157 & 3.834342 \\
\hline $\mathrm{H}$ & 6.790037 & -0.347049 & 2.746998 \\
\hline $\mathrm{H}$ & 7.790646 & -1.796303 & 2.613763 \\
\hline $\mathrm{C}$ & 10.205182 & -0.466874 & 1.984982 \\
\hline $\mathrm{H}$ & 10.307927 & -1.533976 & 1.750299 \\
\hline $\mathrm{H}$ & 10.910416 & 0.079329 & 1.347877 \\
\hline $\mathrm{H}$ & 10.533670 & -0.332389 & 3.025229 \\
\hline $\mathrm{C}$ & 8.706108 & 1.532071 & -0.974147 \\
\hline $\mathrm{H}$ & 8.226567 & 1.429488 & -1.960096 \\
\hline $\mathrm{C}$ & 10.228077 & 1.623697 & -1.204823 \\
\hline $\mathrm{H}$ & 10.770573 & 1.767438 & -0.261929 \\
\hline $\mathrm{H}$ & 10.635006 & 0.727319 & -1.688681 \\
\hline $\mathrm{H}$ & 10.470968 & 2.481533 & -1.847779 \\
\hline $\mathrm{C}$ & 8.173635 & 2.834020 & -0.344031 \\
\hline $\mathrm{H}$ & 8.417011 & 3.699290 & -0.976950 \\
\hline $\mathrm{H}$ & 7.085243 & 2.811783 & -0.216430 \\
\hline $\mathrm{H}$ & 8.622605 & 3.020568 & 0.640587 \\
\hline $\mathrm{H}$ & -1.726152 & 1.288345 & -2.050076 \\
\hline $\mathrm{H}$ & -1.728656 & 2.889016 & -1.338516 \\
\hline $\mathrm{H}$ & -3.290012 & 2.093750 & 0.721103 \\
\hline $\mathrm{H}$ & 0.024629 & 2.777770 & -2.976941 \\
\hline $\mathrm{H}$ & -1.924533 & -1.506376 & 3.339541 \\
\hline & & & \\
\hline
\end{tabular}

\begin{tabular}{|l|l|}
\hline Electronic Energy & -2215.578890 \\
\hline Sum of electronic and zero-point Energies & -2214.668852 \\
\hline Sum of electronic and thermal Energies & -2214.616424 \\
\hline Sum of electronic and thermal Enthalpies & -2214.615479 \\
\hline Sum of electronic and thermal Free Energies & -2214.758169 \\
\hline
\end{tabular}




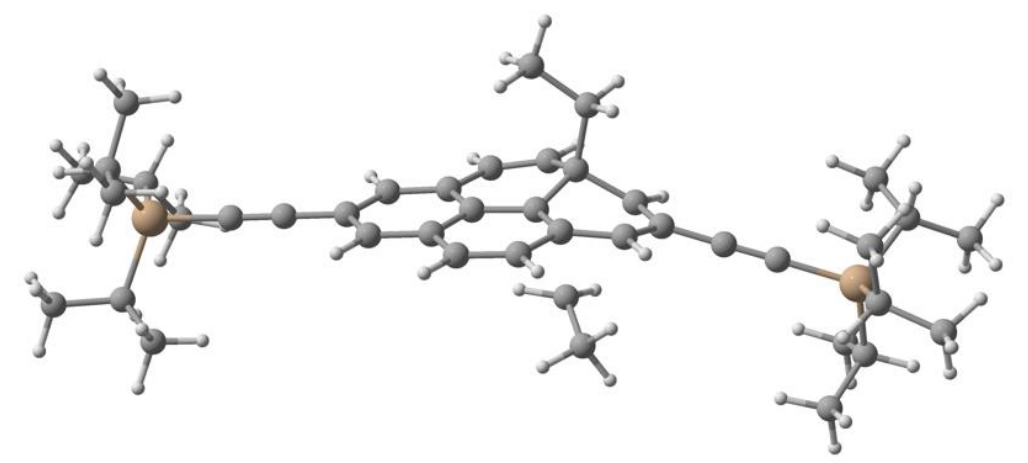

\begin{tabular}{|c|c|c|c|}
\hline \multicolumn{4}{|c|}{ Cartesian Coordinates $/ \AA$} \\
\hline & $\mathrm{X}$ & $\mathrm{y}$ & $\mathrm{Z}$ \\
\hline $\mathrm{C}$ & 3.401148 & -0.282508 & -0.481319 \\
\hline $\mathrm{C}$ & 2.715656 & 0.612423 & -1.347115 \\
\hline $\mathrm{H}$ & 3.274837 & 1.356328 & -1.907080 \\
\hline $\mathrm{C}$ & 1.310236 & 0.625734 & -1.353948 \\
\hline $\mathrm{C}$ & 0.560897 & 1.682550 & -1.984282 \\
\hline $\mathrm{H}$ & 1.105931 & 2.428234 & -2.559306 \\
\hline $\mathrm{C}$ & 0.606937 & -0.356961 & -0.593729 \\
\hline $\mathrm{C}$ & 1.277010 & 0.440781 & 1.713174 \\
\hline $\mathrm{H}$ & 0.203991 & 0.315800 & 1.772396 \\
\hline $\mathrm{H}$ & 1.824424 & -0.214570 & 2.383359 \\
\hline $\mathrm{C}$ & 1.833374 & 1.794429 & 1.482310 \\
\hline $\mathrm{H}$ & 2.502749 & 1.819374 & 0.597281 \\
\hline $\mathrm{H}$ & 2.455071 & 2.124713 & 2.326659 \\
\hline $\mathrm{C}$ & 1.315475 & -1.671604 & -0.316728 \\
\hline $\mathrm{C}$ & 0.548139 & -2.489278 & 0.696676 \\
\hline $\mathrm{H}$ & 1.089024 & -3.296613 & 1.190083 \\
\hline $\mathrm{C}$ & 2.678243 & -1.260951 & 0.195360 \\
\hline $\mathrm{H}$ & 3.194543 & -1.914715 & 0.895616 \\
\hline $\mathrm{C}$ & 4.798152 & -0.100376 & -0.229621 \\
\hline $\mathrm{C}$ & 5.996444 & 0.051870 & -0.034848 \\
\hline $\mathrm{Si}$ & 7.803478 & 0.324961 & 0.229354 \\
\hline $\mathrm{C}$ & 8.039932 & 1.079394 & 1.976561 \\
\hline $\mathrm{H}$ & 9.126981 & 1.200580 & 2.108131 \\
\hline $\mathrm{C}$ & 7.394576 & 2.474915 & 2.095644 \\
\hline $\mathrm{H}$ & 6.310428 & 2.424949 & 1.933286 \\
\hline $\mathrm{H}$ & 7.806158 & 3.189200 & 1.373032 \\
\hline $\mathrm{H}$ & 7.558131 & 2.892916 & 3.099171 \\
\hline $\mathrm{C}$ & 7.531351 & 0.159970 & 3.105395 \\
\hline $\mathrm{H}$ & 7.697478 & 0.624762 & 4.087842 \\
\hline $\mathrm{H}$ & 8.038060 & -0.811852 & 3.114871 \\
\hline $\mathrm{H}$ & 6.454624 & -0.027928 & 3.009011 \\
\hline $\mathrm{C}$ & 8.725854 & -1.349689 & 0.017070 \\
\hline $\mathrm{H}$ & 8.871630 & -1.446357 & -1.070452 \\
\hline $\mathrm{C}$ & 7.917416 & -2.582026 & 0.470114 \\
\hline $\mathrm{H}$ & 8.465900 & -3.506945 & 0.240777 \\
\hline $\mathrm{H}$ & 6.943949 & -2.635118 & -0.028431 \\
\hline $\mathrm{H}$ & 7.733565 & -2.573949 & 1.551714 \\
\hline $\mathrm{C}$ & 10.125034 & -1.350710 & 0.669608 \\
\hline $\mathrm{H}$ & 10.059557 & -1.281975 & 1.762813 \\
\hline $\mathrm{H}$ & 10.753021 & -0.520821 & 0.325322 \\
\hline $\mathrm{C}$ & 10.659080 & -2.282784 & 0.436597 \\
\hline $\mathrm{H}$ & 7.673722 & 1.587472 & -1.114052 \\
\hline
\end{tabular}

\begin{tabular}{|c|c|c|c|}
\hline $\mathrm{H}$ & 9.993833 & 2.499909 & 0.034150 \\
\hline $\mathrm{H}$ & 10.004306 & 2.883530 & -1.692546 \\
\hline $\mathrm{C}$ & 8.093532 & 1.073897 & -2.546332 \\
\hline $\mathrm{H}$ & 8.300629 & 1.862897 & -3.283360 \\
\hline $\mathrm{H}$ & 7.057670 & 0.746144 & -2.690930 \\
\hline $\mathrm{H}$ & 8.748619 & 0.227178 & -2.790359 \\
\hline $\mathrm{C}$ & -3.624850 & -0.074598 & -0.175783 \\
\hline $\mathrm{C}$ & -2.907543 & -1.135621 & 0.431427 \\
\hline $\mathrm{H}$ & -3.451051 & -1.868858 & 1.021310 \\
\hline $\mathrm{C}$ & -1.529548 & -1.248971 & 0.283266 \\
\hline $\mathrm{C}$ & -0.764421 & -2.313752 & 0.929592 \\
\hline $\mathrm{H}$ & -1.292792 & -2.965237 & 1.623558 \\
\hline $\mathrm{C}$ & -0.820747 & -0.278853 & -0.487115 \\
\hline $\mathrm{C}$ & 1.512829 & -2.548303 & -1.617223 \\
\hline $\mathrm{H}$ & 2.076017 & -3.443010 & -1.314620 \\
\hline $\mathrm{H}$ & 2.162314 & -1.987267 & -2.298306 \\
\hline $\mathrm{C}$ & 0.240703 & -2.969845 & -2.360552 \\
\hline $\mathrm{H}$ & -0.438904 & -3.543469 & -1.721465 \\
\hline $\mathrm{H}$ & -0.308166 & -2.103047 & -2.744522 \\
\hline $\mathrm{H}$ & 0.504493 & -3.600683 & -3.218293 \\
\hline $\mathrm{C}$ & -1.531199 & 0.799987 & -1.086328 \\
\hline $\mathrm{C}$ & -0.793807 & 1.767840 & -1.857453 \\
\hline $\mathrm{H}$ & -1.341959 & 2.576799 & -2.335011 \\
\hline $\mathrm{C}$ & -2.927641 & 0.880472 & -0.924949 \\
\hline $\mathrm{H}$ & -3.473818 & 1.699520 & -1.385203 \\
\hline $\mathrm{C}$ & -5.042076 & 0.017883 & -0.018476 \\
\hline $\mathrm{C}$ & -6.255232 & 0.096915 & 0.118607 \\
\hline $\mathrm{Si}$ & -8.092213 & 0.187655 & 0.295302 \\
\hline $\mathrm{C}$ & -8.851113 & 0.100102 & -1.463719 \\
\hline $\mathrm{H}$ & -9.940102 & 0.197793 & -1.328083 \\
\hline $\mathrm{C}$ & -8.584533 & -1.258010 & -2.144416 \\
\hline $\mathrm{H}$ & -7.509199 & -1.430309 & -2.279648 \\
\hline $\mathrm{H}$ & -8.986504 & -2.099951 & -1.568601 \\
\hline $\mathrm{H}$ & -9.050018 & -1.289658 & -3.139740 \\
\hline $\mathrm{C}$ & -8.388556 & 1.253759 & -2.376211 \\
\hline $\mathrm{H}$ & -8.860190 & 1.177378 & -3.366366 \\
\hline $\mathrm{H}$ & -8.644567 & 2.237946 & -1.967672 \\
\hline $\mathrm{H}$ & -7.302103 & 1.228755 & -2.527206 \\
\hline $\mathrm{C}$ & -8.545624 & 1.816464 & 1.214682 \\
\hline $\mathrm{H}$ & -8.426593 & 1.571830 & 2.282009 \\
\hline $\mathrm{C}$ & -7.599632 & 2.997769 & 0.919280 \\
\hline $\mathrm{H}$ & -7.863537 & 3.865542 & 1.540720 \\
\hline $\mathrm{H}$ & -7.662085 & 3.318129 & -0.128125 \\
\hline $\mathrm{H}$ & -10.016451 & 2.232903 & 1.000146 \\
\hline
\end{tabular}




\begin{tabular}{|c|c|c|c|}
\hline H & -10.263402 & 3.108603 & 1.616810 \\
\hline C & -8.601227 & -1.355076 & 1.319725 \\
\hline H & -8.175716 & -2.202691 & 0.760226 \\
\hline C & -10.124653 & -1.574847 & 1.410196 \\
\hline H & -10.611630 & -0.784310 & 1.995316 \\
\hline$H$ & -10.604940 & -1.601692 & 0.424399 \\
\hline
\end{tabular}

\begin{tabular}{|c|c|c|c|}
\hline$H$ & -10.350226 & -2.527609 & 1.909873 \\
\hline C & -7.965361 & -1.371034 & 2.723595 \\
\hline$H$ & -8.170859 & -2.322938 & 3.233716 \\
\hline$H$ & -6.877445 & -1.243772 & 2.681617 \\
\hline$H$ & -8.370297 & -0.572585 & 3.359121 \\
\hline$H$ & 1.048135 & 2.534684 & 1.295848 \\
\hline
\end{tabular}

\begin{tabular}{|l|l|}
\hline Electronic Energy & -2215.533685 \\
\hline Sum of electronic and zero-point Energies & -2214.628398 \\
\hline Sum of electronic and thermal Energies & -2214.576229 \\
\hline Sum of electronic and thermal Enthalpies & -2214.575285 \\
\hline Sum of electronic and thermal Free Energies & -2214.716542 \\
\hline
\end{tabular}

Imaginary mode $=329 i \mathrm{~cm}^{-1}$

10

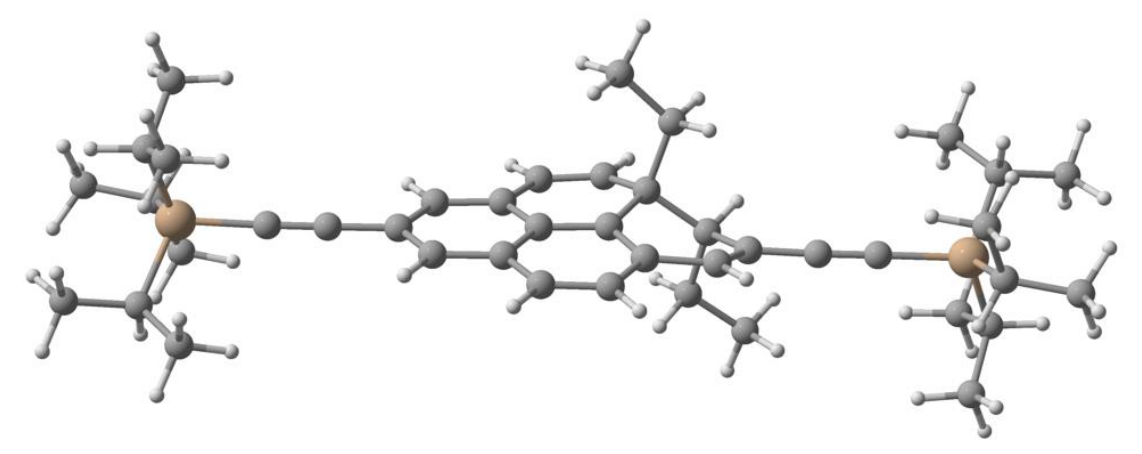

\begin{tabular}{|l|l|l|l|}
\hline \multicolumn{4}{|c|}{ Cartesian Coordinates / $\AA$} \\
\hline & $\mathrm{x}$ & $\mathrm{y}$ & \multicolumn{1}{c|}{$\mathrm{z}$} \\
\hline $\mathrm{C}$ & -3.324743 & 0.236901 & -0.123653 \\
\hline $\mathrm{C}$ & -2.614449 & 1.395442 & -0.087370 \\
\hline H & -3.134701 & 2.350481 & -0.109159 \\
\hline $\mathrm{C}$ & -1.158187 & 1.402882 & -0.048348 \\
\hline $\mathrm{C}$ & -0.425600 & 2.592386 & -0.315643 \\
\hline H & -0.972093 & 3.512657 & -0.510462 \\
\hline $\mathrm{C}$ & -0.471773 & 0.216384 & 0.233310 \\
\hline $\mathrm{C}$ & -2.307947 & -1.534989 & -1.637374 \\
\hline H & -1.706568 & -0.761002 & -2.131360 \\
\hline H & -1.687064 & -2.439235 & -1.618674 \\
\hline $\mathrm{C}$ & -3.566398 & -1.815467 & -2.466678 \\
\hline H & -4.185482 & -0.921170 & -2.588616 \\
\hline H & -4.188584 & -2.589023 & -1.998710 \\
\hline $\mathrm{C}$ & -1.272563 & -1.002030 & 0.683419 \\
\hline $\mathrm{C}$ & -0.455790 & -2.269445 & 0.592128 \\
\hline H & -0.997934 & -3.205835 & 0.721801 \\
\hline $\mathrm{C}$ & -2.577551 & -1.103680 & -0.170624 \\
\hline H & -3.213684 & -1.869432 & 0.294230 \\
\hline $\mathrm{C}$ & -4.745201 & 0.244204 & -0.132587 \\
\hline $\mathrm{C}$ & -5.970664 & 0.224054 & -0.105656 \\
\hline $\mathrm{Si}$ & -7.816830 & 0.253917 & -0.063740 \\
\hline
\end{tabular}

\begin{tabular}{|l|l|l|l|}
\hline C & -8.465094 & -0.493476 & -1.706536 \\
\hline$H$ & -9.563563 & -0.492499 & -1.621835 \\
\hline C & -8.088233 & 0.368644 & -2.928801 \\
\hline$H$ & -6.999290 & 0.432428 & -3.049312 \\
\hline$H$ & -8.474660 & 1.392130 & -2.856127 \\
\hline$H$ & -8.494676 & -0.069890 & -3.851297 \\
\hline C & -8.014977 & -1.951796 & -1.924280 \\
\hline H & -8.423072 & -2.346860 & -2.865635 \\
\hline H & -8.349049 & -2.616155 & -1.119430 \\
\hline H & -6.922259 & -2.025503 & -1.984079 \\
\hline C & -8.416733 & -0.728610 & 1.478372 \\
\hline H & -8.356249 & -0.003722 & 2.305523 \\
\hline C & -7.519643 & -1.921848 & 1.865134 \\
\hline$H$ & -7.875510 & -2.382458 & 2.797856 \\
\hline$H$ & -6.478756 & -1.617029 & 2.016013 \\
\hline$H$ & -7.526177 & -2.702616 & 1.094549 \\
\hline C & -9.890162 & -1.176504 & 1.366718 \\
\hline$H$ & -10.024703 & -1.926163 & 0.576695 \\
\hline$H$ & -10.570238 & -0.344609 & 1.149692 \\
\hline$H$ & -10.225447 & -1.635665 & 2.307406 \\
\hline C & -8.312341 & 2.105367 & 0.058428 \\
\hline$H$ & -7.811281 & 2.574862 & -0.802501 \\
\hline$C$ & -9.825823 & 2.361790 & -0.087107 \\
\hline
\end{tabular}




\begin{tabular}{|l|l|l|l|}
\hline $\mathrm{H}$ & -10.386849 & 1.954867 & 0.763786 \\
\hline $\mathrm{H}$ & -10.241968 & 1.920312 & -1.000845 \\
\hline $\mathrm{H}$ & -10.034511 & 3.440515 & -0.120603 \\
\hline $\mathrm{C}$ & -7.766479 & 2.787631 & 1.328151 \\
\hline $\mathrm{H}$ & -7.960276 & 3.869422 & 1.302322 \\
\hline $\mathrm{H}$ & -6.684954 & 2.646095 & 1.437324 \\
\hline $\mathrm{H}$ & -8.247679 & 2.397504 & 2.234574 \\
\hline $\mathrm{C}$ & 3.772977 & 0.135902 & -0.021796 \\
\hline $\mathrm{C}$ & 3.033361 & -1.065489 & 0.201800 \\
\hline $\mathrm{H}$ & 3.576749 & -2.001541 & 0.299898 \\
\hline $\mathrm{C}$ & 1.654941 & -1.055909 & 0.285168 \\
\hline $\mathrm{C}$ & 0.880392 & -2.283332 & 0.459470 \\
\hline $\mathrm{H}$ & 1.425524 & -3.225595 & 0.466002 \\
\hline $\mathrm{C}$ & 0.941286 & 0.183172 & 0.145230 \\
\hline $\mathrm{C}$ & -1.690803 & -0.839399 & 2.198215 \\
\hline $\mathrm{H}$ & -2.257291 & -1.741996 & 2.469490 \\
\hline $\mathrm{H}$ & -2.389100 & 0.000491 & 2.275119 \\
\hline $\mathrm{C}$ & -0.551374 & -0.633847 & 3.201062 \\
\hline $\mathrm{H}$ & 0.169641 & -1.457840 & 3.178228 \\
\hline $\mathrm{H}$ & -0.006781 & 0.297177 & 3.010244 \\
\hline $\mathrm{H}$ & -0.959801 & -0.574855 & 4.217155 \\
\hline $\mathrm{C}$ & 1.673036 & 1.382699 & -0.131610 \\
\hline $\mathrm{C}$ & 0.950215 & 2.589077 & -0.339818 \\
\hline $\mathrm{H}$ & 1.499847 & 3.506388 & -0.537422 \\
\hline $\mathrm{C}$ & 3.088979 & 1.333472 & -0.193966 \\
\hline $\mathrm{H}$ & 3.644569 & 2.247585 & -0.384711 \\
\hline $\mathrm{C}$ & 5.199900 & 0.092919 & -0.076177 \\
\hline $\mathrm{C}$ & 6.421883 & 0.049064 & -0.117331 \\
\hline $\mathrm{Si}$ & 8.268153 & -0.017713 & -0.126041 \\
\hline $\mathrm{C}$ & 8.882606 & 0.711404 & 1.537785 \\
\hline
\end{tabular}

\begin{tabular}{|l|l|l|l|}
\hline $\mathrm{H}$ & 9.982788 & 0.701710 & 1.481966 \\
\hline $\mathrm{C}$ & 8.465675 & -0.155331 & 2.743691 \\
\hline $\mathrm{H}$ & 7.373264 & -0.210627 & 2.833570 \\
\hline $\mathrm{H}$ & 8.846553 & -1.181282 & 2.675484 \\
\hline $\mathrm{H}$ & 8.850024 & 0.274600 & 3.679633 \\
\hline $\mathrm{C}$ & 8.437488 & 2.171672 & 1.753904 \\
\hline $\mathrm{H}$ & 8.824956 & 2.557672 & 2.707611 \\
\hline $\mathrm{H}$ & 8.795478 & 2.839106 & 0.961893 \\
\hline $\mathrm{H}$ & 7.343836 & 2.252004 & 1.787209 \\
\hline $\mathrm{C}$ & 8.920143 & 0.961914 & -1.647827 \\
\hline $\mathrm{H}$ & 8.878653 & 0.239126 & -2.478017 \\
\hline $\mathrm{C}$ & 8.044250 & 2.162827 & -2.059207 \\
\hline $\mathrm{H}$ & 8.432390 & 2.622480 & -2.979439 \\
\hline $\mathrm{H}$ & 7.006238 & 1.866622 & -2.243269 \\
\hline $\mathrm{H}$ & 8.032880 & 2.942156 & -1.287164 \\
\hline $\mathrm{C}$ & 10.393262 & 1.398128 & -1.492090 \\
\hline $\mathrm{H}$ & 10.509868 & 2.146256 & -0.697818 \\
\hline $\mathrm{H}$ & 11.060365 & 0.560943 & -1.255677 \\
\hline $\mathrm{H}$ & 10.759504 & 1.855417 & -2.422071 \\
\hline $\mathrm{C}$ & 8.734649 & -1.875899 & -0.248989 \\
\hline $\mathrm{H}$ & 8.216081 & -2.342249 & 0.603210 \\
\hline $\mathrm{C}$ & 10.242471 & -2.153409 & -0.085631 \\
\hline $\mathrm{H}$ & 10.819188 & -1.748178 & -0.926778 \\
\hline $\mathrm{H}$ & 10.652237 & -1.722727 & 0.836176 \\
\hline $\mathrm{H}$ & 10.436818 & -3.234918 & -0.056328 \\
\hline $\mathrm{C}$ & 8.195171 & -2.543663 & -1.529184 \\
\hline $\mathrm{H}$ & 8.375289 & -3.627920 & -1.507672 \\
\hline $\mathrm{H}$ & 7.116852 & -2.387999 & -1.650069 \\
\hline $\mathrm{H}$ & 8.691461 & -2.154210 & -2.427739 \\
\hline $\mathrm{H}$ & -3.290275 & -2.169936 & -3.467109 \\
\hline & & & \\
\hline
\end{tabular}

\begin{tabular}{|l|l|}
\hline Electronic Energy & -2215.635968 \\
\hline Sum of electronic and zero-point Energies & -2214.725179 \\
\hline Sum of electronic and thermal Energies & -2214.672471 \\
\hline Sum of electronic and thermal Enthalpies & -2214.671527 \\
\hline Sum of electronic and thermal Free Energies & -2214.815568 \\
\hline
\end{tabular}


11 (Calcs Point 9)

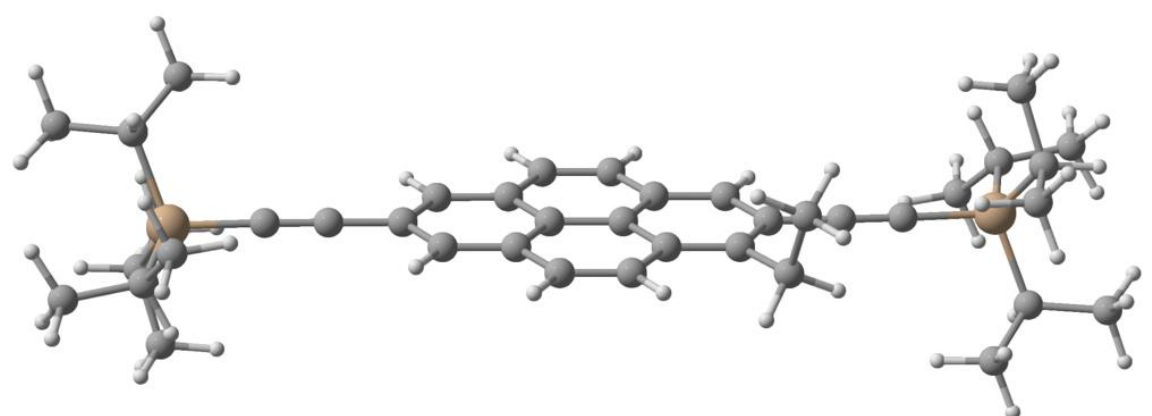

\begin{tabular}{|l|l|l|l|}
\hline \multicolumn{4}{|c|}{ Cartesian Coordinates $/$} \\
\hline & \multicolumn{1}{|c|}{$\mathrm{X}$} & \multicolumn{1}{|c|}{$\mathrm{y}$} & \multicolumn{1}{|c|}{$\mathrm{Z}$} \\
\hline $\mathrm{C}$ & -3.351549 & -0.030667 & -0.027400 \\
\hline $\mathrm{C}$ & -2.639275 & -1.237470 & 0.087096 \\
\hline $\mathrm{C}$ & -1.242933 & -1.262900 & 0.091782 \\
\hline $\mathrm{C}$ & -0.503094 & -2.492665 & 0.203532 \\
\hline $\mathrm{H}$ & -1.060168 & -3.423081 & 0.286555 \\
\hline $\mathrm{C}$ & -0.531324 & -0.029482 & -0.018562 \\
\hline $\mathrm{C}$ & -3.661087 & 3.191701 & 1.116115 \\
\hline $\mathrm{H}$ & -4.203103 & 2.539567 & 1.809886 \\
\hline $\mathrm{C}$ & -1.251186 & 1.204108 & -0.132266 \\
\hline $\mathrm{C}$ & -0.476209 & 2.417299 & -0.234849 \\
\hline $\mathrm{H}$ & -0.990512 & 3.368305 & -0.316526 \\
\hline $\mathrm{C}$ & -2.667754 & 1.206109 & -0.142759 \\
\hline $\mathrm{C}$ & -4.782494 & -0.095222 & -0.028024 \\
\hline $\mathrm{C}$ & -6.002179 & -0.192061 & -0.031304 \\
\hline $\mathrm{Si}$ & -7.841581 & -0.376365 & -0.021160 \\
\hline $\mathrm{C}$ & -8.543516 & 0.802776 & 1.317686 \\
\hline $\mathrm{H}$ & -9.639390 & 0.705628 & 1.259923 \\
\hline $\mathrm{C}$ & -8.110447 & 0.395126 & 2.740580 \\
\hline $\mathrm{H}$ & -7.019102 & 0.432943 & 2.850344 \\
\hline $\mathrm{H}$ & -8.435546 & -0.618470 & 3.002767 \\
\hline $\mathrm{H}$ & -8.538960 & 1.079644 & 3.486403 \\
\hline $\mathrm{C}$ & -8.190781 & 2.281123 & 1.057004 \\
\hline $\mathrm{H}$ & -8.632559 & 2.927106 & 1.829094 \\
\hline $\mathrm{H}$ & -8.557283 & 2.634295 & 0.086407 \\
\hline $\mathrm{H}$ & -7.105276 & 2.438511 & 1.079495 \\
\hline $\mathrm{C}$ & -8.517724 & 0.021383 & -1.778420 \\
\hline $\mathrm{H}$ & -8.424208 & -0.926965 & -2.330724 \\
\hline $\mathrm{C}$ & -7.699649 & 1.073232 & -2.554251 \\
\hline $\mathrm{H}$ & -8.099960 & 1.197998 & -3.570566 \\
\hline $\mathrm{H}$ & -6.646173 & 0.787607 & -2.641230 \\
\hline $\mathrm{H}$ & -7.736095 & 2.056391 & -2.068542 \\
\hline $\mathrm{C}$ & -10.014603 & 0.400616 & -1.771300 \\
\hline $\mathrm{H}$ & -10.185035 & 1.360034 & -1.267103 \\
\hline $\mathrm{H}$ & -10.638945 & -0.348911 & -1.271496 \\
\hline $\mathrm{H}$ & -10.389700 & 0.505567 & -2.799040 \\
\hline $\mathrm{C}$ & -8.185868 & -2.203863 & 0.455304 \\
\hline $\mathrm{H}$ & -7.681330 & -2.332169 & 1.425627 \\
\hline $\mathrm{C}$ & -9.680151 & -2.524984 & 0.661301 \\
\hline $\mathrm{H}$ & -10.239241 & -2.461842 & -0.281051 \\
\hline $\mathrm{H}$ & -10.161511 & -1.849952 & 1.379443 \\
\hline $\mathrm{H}$ & -9.807087 & -3.549168 & 1.039575 \\
\hline & -7.547706 & -3.208000 & -0.524914 \\
\hline $\mathrm{H}$ & -6.675286 & -4.238194 & -0.163084 \\
\hline
\end{tabular}

\begin{tabular}{|l|l|l|l|}
\hline $\mathrm{C}$ & 0.886720 & 2.406208 & -0.229709 \\
\hline $\mathrm{H}$ & 1.439533 & 3.339499 & -0.309685 \\
\hline $\mathrm{C}$ & 0.896248 & -0.041776 & -0.014019 \\
\hline $\mathrm{C}$ & 1.608784 & -1.277399 & 0.097098 \\
\hline $\mathrm{C}$ & 0.858422 & -2.501251 & 0.205575 \\
\hline $\mathrm{H}$ & 1.404516 & -3.437855 & 0.290220 \\
\hline $\mathrm{C}$ & 3.009680 & -1.266082 & 0.097974 \\
\hline $\mathrm{H}$ & 3.553238 & -2.203057 & 0.182917 \\
\hline $\mathrm{C}$ & 5.159883 & -0.070213 & -0.009728 \\
\hline $\mathrm{C}$ & 6.382919 & -0.070115 & -0.008241 \\
\hline $\mathrm{Si}$ & 8.230791 & -0.037970 & -0.041113 \\
\hline $\mathrm{C}$ & 8.816462 & -1.321452 & -1.339089 \\
\hline $\mathrm{H}$ & 9.917546 & -1.304756 & -1.302575 \\
\hline $\mathrm{C}$ & 8.389032 & -0.939995 & -2.770991 \\
\hline $\mathrm{H}$ & 7.295978 & -0.908889 & -2.864415 \\
\hline $\mathrm{H}$ & 8.777239 & 0.038309 & -3.077672 \\
\hline $\mathrm{H}$ & 8.758803 & -1.680345 & -3.494607 \\
\hline $\mathrm{C}$ & 8.360201 & -2.758173 & -1.013860 \\
\hline $\mathrm{H}$ & 8.733680 & -3.463187 & -1.770223 \\
\hline $\mathrm{H}$ & 8.723253 & -3.102630 & -0.038924 \\
\hline $\mathrm{H}$ & 7.265660 & -2.834543 & -1.006660 \\
\hline $\mathrm{C}$ & 8.891120 & -0.418584 & 1.725067 \\
\hline $\mathrm{H}$ & 8.864043 & 0.552536 & 2.244164 \\
\hline $\mathrm{C}$ & 8.009904 & -1.386684 & 2.539918 \\
\hline $\mathrm{H}$ & 8.407135 & -1.502211 & 3.558569 \\
\hline $\mathrm{H}$ & 6.977787 & -1.029890 & 2.620017 \\
\hline $\mathrm{H}$ & 7.978156 & -2.386204 & 2.088852 \\
\hline $\mathrm{C}$ & 10.359609 & -0.895951 & 1.723002 \\
\hline $\mathrm{H}$ & 10.462594 & -1.879260 & 1.247430 \\
\hline $\mathrm{H}$ & 11.028503 & -0.204744 & 1.197256 \\
\hline $\mathrm{H}$ & 10.733960 & -0.994347 & 2.751683 \\
\hline $\mathrm{C}$ & 8.711336 & 1.735825 & -0.596255 \\
\hline $\mathrm{H}$ & 8.196828 & 1.864693 & -1.561263 \\
\hline $\mathrm{C}$ & 10.220968 & 1.930167 & -0.844681 \\
\hline $\mathrm{H}$ & 10.795201 & 1.863891 & 0.088363 \\
\hline $\mathrm{H}$ & 10.632266 & 1.189734 & -1.541641 \\
\hline $\mathrm{H}$ & 10.417888 & 2.924368 & -1.270239 \\
\hline $\mathrm{C}$ & 8.174575 & 2.825018 & 0.353360 \\
\hline $\mathrm{H}$ & 8.366392 & 3.826829 & -0.056618 \\
\hline $\mathrm{H}$ & 7.094340 & 2.732313 & 0.514235 \\
\hline $\mathrm{H}$ & 8.663083 & 2.781669 & 1.335679 \\
\hline $\mathrm{C}$ & -3.458310 & 2.494207 & -0.244381 \\
\hline $\mathrm{H}$ & -4.439584 & 2.273809 & -0.675560 \\
\hline $\mathrm{H}$ & -2.968879 & 3.185083 & -0.940239 \\
\hline $\mathrm{H}$ & -2.703842 & 3.452890 & 1.581680 \\
\hline $\mathrm{H}$ & -3.242606 & 4.113221 & 0.991855 \\
\hline & 3.584250 & 2.081994 & -0.200454 \\
\hline
\end{tabular}




\begin{tabular}{|l|l|}
\hline Electronic Energy & -2135.851698 \\
\hline Sum of electronic and zero-point Energies & -2135.019674 \\
\hline Sum of electronic and thermal Energies & -2134.970395 \\
\hline Sum of electronic and thermal Enthalpies & -2134.969451 \\
\hline Sum of electronic and thermal Free Energies & -2135.106615 \\
\hline
\end{tabular}

12 (Calcs Point 10)

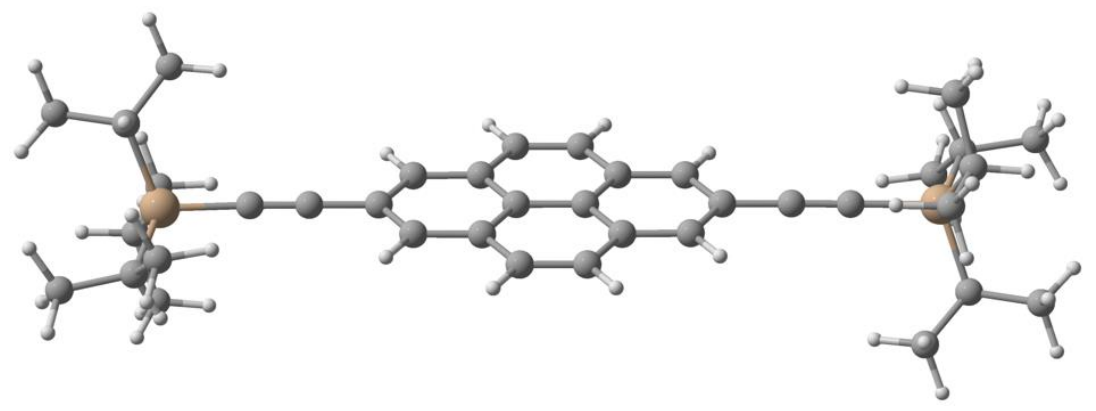

\begin{tabular}{|c|c|c|c|}
\hline \multicolumn{4}{|c|}{ Cartesian Coordinates / $\AA$} \\
\hline & \multicolumn{1}{|c|}{$\mathrm{X}$} & \multicolumn{1}{c|}{$\mathrm{y}$} & $\mathrm{Z}$ \\
\hline $\mathrm{C}$ & 3.543351 & 0.115984 & -0.012280 \\
\hline $\mathrm{C}$ & 2.821285 & 1.323712 & -0.015950 \\
\hline $\mathrm{C}$ & 1.420023 & 1.329520 & -0.016303 \\
\hline $\mathrm{C}$ & 0.657528 & 2.551358 & -0.020186 \\
\hline $\mathrm{H}$ & 1.196158 & 3.496144 & -0.023929 \\
\hline $\mathrm{C}$ & 0.715075 & 0.086189 & -0.012137 \\
\hline $\mathrm{C}$ & 1.445744 & -1.142099 & -0.008611 \\
\hline $\mathrm{C}$ & 0.710609 & -2.380538 & -0.004077 \\
\hline $\mathrm{H}$ & 1.270104 & -3.313116 & -0.001288 \\
\hline $\mathrm{C}$ & 2.845862 & -1.106544 & -0.009215 \\
\hline $\mathrm{C}$ & 4.973327 & 0.122298 & -0.010229 \\
\hline $\mathrm{C}$ & 6.196253 & 0.108104 & -0.011074 \\
\hline $\mathrm{Si}$ & 8.043484 & 0.041713 & 0.021042 \\
\hline $\mathrm{C}$ & 8.549604 & -1.054565 & 1.511395 \\
\hline $\mathrm{H}$ & 9.647612 & -1.132597 & 1.469086 \\
\hline $\mathrm{C}$ & 8.175004 & -0.411887 & 2.862496 \\
\hline $\mathrm{H}$ & 7.089664 & -0.274033 & 2.949247 \\
\hline $\mathrm{H}$ & 8.646899 & 0.567070 & 3.006976 \\
\hline $\mathrm{H}$ & 8.491463 & -1.053947 & 3.696769 \\
\hline $\mathrm{C}$ & 7.975964 & -2.482956 & 1.425211 \\
\hline $\mathrm{H}$ & 8.305855 & -3.085412 & 2.283569 \\
\hline $\mathrm{H}$ & 8.293567 & -3.006642 & 0.516527 \\
\hline $\mathrm{H}$ & 6.879075 & -2.469572 & 1.435100 \\
\hline $\mathrm{C}$ & 8.665251 & -0.662936 & -1.658463 \\
\hline $\mathrm{H}$ & 8.716158 & 0.214369 & -2.322510 \\
\hline $\mathrm{C}$ & 7.704265 & -1.670951 & -2.320019 \\
\hline $\mathrm{H}$ & 8.082990 & -1.971122 & -3.307562 \\
\hline $\mathrm{H}$ & 6.702414 & -1.250932 & -2.457223 \\
\hline $\mathrm{H}$ & 7.598949 & -2.584416 & -1.721694 \\
\hline $\mathrm{C}$ & 10.089243 & -1.252965 & -1.568860 \\
\hline & & & \\
\hline
\end{tabular}

\begin{tabular}{|l|l|l|l|}
\hline $\mathrm{H}$ & 10.113508 & -2.154699 & -0.943859 \\
\hline $\mathrm{H}$ & 10.815521 & -0.544900 & -1.153084 \\
\hline $\mathrm{H}$ & 10.449150 & -1.542186 & -2.566254 \\
\hline $\mathrm{C}$ & 8.648392 & 1.844277 & 0.284483 \\
\hline $\mathrm{H}$ & 8.158692 & 2.163104 & 1.217746 \\
\hline $\mathrm{C}$ & 10.171636 & 1.963844 & 0.492784 \\
\hline $\mathrm{H}$ & 10.724584 & 1.690864 & -0.415050 \\
\hline $\mathrm{H}$ & 10.535563 & 1.326437 & 1.307899 \\
\hline $\mathrm{H}$ & 10.449243 & 2.998788 & 0.737680 \\
\hline $\mathrm{C}$ & 8.176385 & 2.802993 & -0.826547 \\
\hline $\mathrm{H}$ & 8.445126 & 3.840871 & -0.583570 \\
\hline $\mathrm{H}$ & 7.089991 & 2.765148 & -0.967258 \\
\hline $\mathrm{H}$ & 8.646208 & 2.567742 & -1.790546 \\
\hline $\mathrm{C}$ & -3.537856 & 0.039511 & -0.008243 \\
\hline $\mathrm{C}$ & -2.814187 & -1.167587 & -0.005635 \\
\hline $\mathrm{C}$ & -1.413583 & -1.172968 & -0.006458 \\
\hline $\mathrm{C}$ & -0.651845 & -2.395222 & -0.003036 \\
\hline $\mathrm{H}$ & -1.191003 & -3.339695 & 0.000608 \\
\hline $\mathrm{C}$ & -0.709526 & 0.070823 & -0.010963 \\
\hline $\mathrm{C}$ & -1.441100 & 1.298597 & -0.014193 \\
\hline $\mathrm{C}$ & -0.705223 & 2.536654 & -0.019175 \\
\hline $\mathrm{H}$ & -1.264203 & 3.469554 & -0.022095 \\
\hline $\mathrm{C}$ & -2.841865 & 1.262563 & -0.012349 \\
\hline $\mathrm{H}$ & -3.403649 & 2.192603 & -0.014215 \\
\hline $\mathrm{C}$ & -4.967721 & 0.017774 & -0.007064 \\
\hline $\mathrm{C}$ & -6.190333 & -0.013055 & -0.002152 \\
\hline $\mathrm{Si}$ & -8.037311 & -0.094632 & -0.024079 \\
\hline $\mathrm{C}$ & -8.661401 & 1.150113 & -1.341567 \\
\hline $\mathrm{H}$ & -9.761449 & 1.106065 & -1.299292 \\
\hline $\mathrm{C}$ & -8.230305 & 0.754500 & -2.768541 \\
\hline $\mathrm{H}$ & -7.137170 & 0.748172 & -2.865991 \\
\hline $\mathrm{H}$ & -8.595682 & -0.238127 & -3.056774 \\
\hline & & & \\
\hline
\end{tabular}




\begin{tabular}{|l|l|l|l|}
\hline$H$ & -8.620695 & 1.473046 & -3.503196 \\
\hline $\mathrm{C}$ & -8.240239 & 2.603167 & -1.042842 \\
\hline $\mathrm{H}$ & -8.633613 & 3.285543 & -1.809770 \\
\hline $\mathrm{H}$ & -8.608538 & 2.955082 & -0.072550 \\
\hline $\mathrm{H}$ & -7.147901 & 2.706519 & -1.040839 \\
\hline $\mathrm{C}$ & -8.696517 & 0.301572 & 1.739032 \\
\hline $\mathrm{H}$ & -8.639072 & -0.657981 & 2.276812 \\
\hline $\mathrm{C}$ & -7.837356 & 1.309786 & 2.528496 \\
\hline $\mathrm{H}$ & -8.230037 & 1.433134 & 3.547970 \\
\hline $\mathrm{H}$ & -6.794757 & 0.984478 & 2.606891 \\
\hline $\mathrm{H}$ & -7.838003 & 2.301017 & 2.058418 \\
\hline $\mathrm{C}$ & -10.177728 & 0.737827 & 1.738290 \\
\hline $\mathrm{H}$ & -10.311499 & 1.708885 & 1.245479 \\
\hline $\mathrm{H}$ & -10.830297 & 0.018470 & 1.230202 \\
\hline $\mathrm{H}$ & -10.548010 & 0.844895 & 2.767563 \\
\hline
\end{tabular}

\begin{tabular}{|l|l|l|l|}
\hline $\mathrm{C}$ & -8.473462 & -1.890639 & -0.543644 \\
\hline $\mathrm{H}$ & -7.959228 & -2.024830 & -1.508066 \\
\hline $\mathrm{C}$ & -9.978331 & -2.129341 & -0.782188 \\
\hline $\mathrm{H}$ & -10.550994 & -2.060800 & 0.151626 \\
\hline $\mathrm{H}$ & -10.411422 & -1.413268 & -1.491225 \\
\hline $\mathrm{H}$ & -10.150261 & -3.136187 & -1.188325 \\
\hline $\mathrm{C}$ & -7.904998 & -2.946959 & 0.424574 \\
\hline $\mathrm{H}$ & -8.074996 & -3.961240 & 0.036248 \\
\hline $\mathrm{H}$ & -6.826358 & -2.825188 & 0.576463 \\
\hline $\mathrm{H}$ & -8.388419 & -2.895105 & 1.408989 \\
\hline $\mathrm{H}$ & 3.407358 & -2.036727 & -0.006707 \\
\hline $\mathrm{H}$ & 3.362799 & 2.265704 & -0.018108 \\
\hline $\mathrm{H}$ & -3.355187 & -2.109838 & -0.002917 \\
\hline
\end{tabular}

\begin{tabular}{|l|l|}
\hline Electronic Energy & -2057.222991 \\
\hline Sum of electronic and zero-point Energies & -2056.447736 \\
\hline Sum of electronic and thermal Energies & -2056.401397 \\
\hline Sum of electronic and thermal Enthalpies & -2056.400453 \\
\hline Sum of electronic and thermal Free Energies & -2056.531351 \\
\hline
\end{tabular}


Table S4. Reaction energetics for the transformation of DHP 8 to pyrene 12.

\begin{tabular}{|c|c|c|c|c|c|c|c|}
\hline & Energy & $8 \rightarrow 9$ & $\begin{array}{c}8 \rightarrow 9 \\
\text { Barrier }\end{array}$ & $9 \rightarrow 10$ & $\begin{array}{l}9 \rightarrow 10 \\
\text { Barrier }\end{array}$ & $\begin{array}{r}10 \rightarrow 11 \\
+ \text { ethane }\end{array}$ & $\begin{array}{r}10 \rightarrow 12 \\
+ \text { butane }\end{array}$ \\
\hline \multirow{5}{*}{ 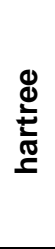 } & $\Delta \mathrm{E}$ & 0.004324 & 0.054324 & -0.057078 & 0.045205 & -0.046148 & -0.045070 \\
\hline & $\Delta\left(E_{+}\right.$zpe $)$ & 0.005249 & 0.049631 & -0.056327 & 0.040455 & -0.049671 & -0.047802 \\
\hline & $\Delta(E+$ thermal $)$ & 0.005103 & 0.049479 & -0.056047 & 0.040195 & -0.049632 & -0.048405 \\
\hline & $\Delta \mathbf{H}$ & 0.005104 & 0.049479 & -0.056048 & 0.040195 & -0.048688 & -0.047461 \\
\hline & $\Delta \mathbf{G}$ & 0.005797 & 0.050694 & -0.057399 & 0.041629 & -0.067641 & -0.068392 \\
\hline \multirow{5}{*}{$\begin{array}{l}\overline{0} \\
\text { 롤 } \\
\text { }\end{array}$} & $\Delta \mathrm{E}$ & 11.4 & 142.6 & -149.9 & 118.7 & -121.2 & -118.3 \\
\hline & $\Delta(E+z p e)$ & 13.8 & 130.3 & -147.9 & 106.2 & -130.4 & -125.5 \\
\hline & $\Delta(E+$ thermal $)$ & 13.4 & 129.9 & -147.2 & 105.5 & -130.3 & -127.1 \\
\hline & $\Delta \mathbf{H}$ & 13.4 & 129.9 & -147.2 & 105.5 & -127.8 & -124.6 \\
\hline & $\Delta \mathbf{G}$ & 15.2 & 133.1 & -150.7 & 109.3 & -177.6 & -179.6 \\
\hline \multirow{5}{*}{ 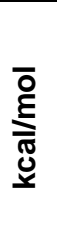 } & $\Delta \mathrm{E}$ & 2.7 & 34.1 & -35.8 & 28.4 & -29.0 & -28.3 \\
\hline & $\Delta(E+z p e)$ & 3.3 & 31.1 & -35.3 & 25.4 & -31.2 & -30.0 \\
\hline & $\Delta(E+$ thermal $)$ & 3.2 & 31.0 & -35.2 & 25.2 & -31.1 & -30.4 \\
\hline & DH & 3.2 & 31.0 & -35.2 & 25.2 & -30.6 & -29.8 \\
\hline & DG & 3.6 & 31.8 & -36.0 & 26.1 & -42.4 & -42.9 \\
\hline
\end{tabular}


1b

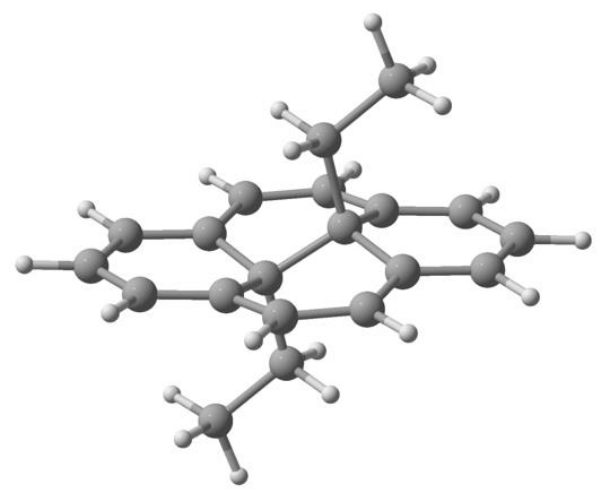

\begin{tabular}{|c|c|c|l|}
\hline \multicolumn{4}{|c|}{ Cartesian Coordinates / } \\
\hline & $\mathrm{X}$ & $\mathrm{y}$ & \multicolumn{1}{c|}{$\mathrm{z}$} \\
\hline $\mathrm{C}$ & -0.843503 & 3.408782 & 0.000000 \\
\hline $\mathrm{C}$ & -0.659837 & 2.753087 & 1.226283 \\
\hline $\mathrm{H}$ & -0.906497 & 3.271527 & 2.151697 \\
\hline $\mathrm{C}$ & -0.238264 & 1.424015 & 1.284009 \\
\hline $\mathrm{C}$ & -0.152465 & 0.683396 & 2.473738 \\
\hline $\mathrm{H}$ & -0.318309 & 1.193626 & 3.421209 \\
\hline $\mathrm{C}$ & 0.238267 & 0.740604 & 0.000000 \\
\hline $\mathrm{C}$ & 1.824348 & 0.800724 & 0.000000 \\
\hline $\mathrm{H}$ & 2.177893 & 0.252167 & 0.878762 \\
\hline $\mathrm{H}$ & 2.177893 & 0.252167 & -0.878762 \\
\hline $\mathrm{C}$ & 2.468035 & 2.192241 & 0.000000 \\
\hline $\mathrm{H}$ & 2.195354 & 2.773843 & 0.886750 \\
\hline $\mathrm{H}$ & 2.195354 & 2.773843 & -0.886750 \\
\hline $\mathrm{C}$ & -0.238264 & 1.424015 & -1.284009 \\
\hline $\mathrm{C}$ & -0.152465 & 0.683396 & -2.473738 \\
\hline $\mathrm{H}$ & -0.318309 & 1.193626 & -3.421209 \\
\hline $\mathrm{C}$ & -0.659837 & 2.753087 & -1.226283 \\
\hline $\mathrm{H}$ & -0.906497 & 3.271527 & -2.151697 \\
\hline $\mathrm{C}$ & 0.843503 & -3.408782 & 0.000000 \\
\hline
\end{tabular}

\begin{tabular}{|l|l|l|l|}
\hline $\mathrm{C}$ & 0.659837 & -2.753087 & -1.226283 \\
\hline $\mathrm{H}$ & 0.906497 & -3.271527 & -2.151697 \\
\hline $\mathrm{C}$ & 0.238264 & -1.424015 & -1.284009 \\
\hline $\mathrm{C}$ & 0.152465 & -0.683396 & -2.473738 \\
\hline $\mathrm{H}$ & 0.318309 & -1.193626 & -3.421209 \\
\hline $\mathrm{C}$ & -0.238267 & -0.740604 & 0.000000 \\
\hline $\mathrm{C}$ & -1.824348 & -0.800724 & 0.000000 \\
\hline $\mathrm{H}$ & -2.177893 & -0.252167 & -0.878762 \\
\hline $\mathrm{H}$ & -2.177893 & -0.252167 & 0.878762 \\
\hline $\mathrm{C}$ & -2.468035 & -2.192241 & 0.000000 \\
\hline $\mathrm{H}$ & -2.195354 & -2.773843 & -0.886750 \\
\hline $\mathrm{H}$ & -2.195354 & -2.773843 & 0.886750 \\
\hline $\mathrm{C}$ & 0.238264 & -1.424015 & 1.284009 \\
\hline $\mathrm{C}$ & 0.152465 & -0.683396 & 2.473738 \\
\hline $\mathrm{H}$ & 0.318309 & -1.193626 & 3.421209 \\
\hline $\mathrm{C}$ & 0.659837 & -2.753087 & 1.226283 \\
\hline $\mathrm{H}$ & 0.906497 & -3.271527 & 2.151697 \\
\hline $\mathrm{H}$ & -3.559616 & -2.083005 & 0.000000 \\
\hline $\mathrm{H}$ & 3.559616 & 2.083005 & 0.000000 \\
\hline $\mathrm{H}$ & 1.197677 & -4.436793 & 0.000000 \\
\hline $\mathrm{H}$ & -1.197677 & 4.436793 & 0.000000 \\
\hline
\end{tabular}

\begin{tabular}{|l|l|}
\hline Electronic Energy & -774.147166 \\
\hline Sum of electronic and zero-point Energies & -773.806099 \\
\hline Sum of electronic and thermal Energies & -773.789894 \\
\hline Sum of electronic and thermal Enthalpies & -773.788950 \\
\hline Sum of electronic and thermal Free Energies & -773.846649 \\
\hline
\end{tabular}


1b-3b TS

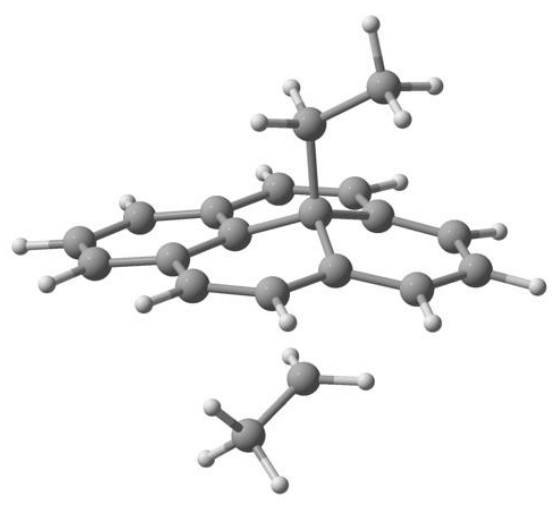

\begin{tabular}{|c|c|c|l|}
\hline \multicolumn{4}{|c|}{ Cartesian Coordinates / } \\
\hline & $\mathrm{X}$ & $\mathrm{y}$ & \multicolumn{1}{c|}{$\mathrm{z}$} \\
\hline $\mathrm{C}$ & -3.189106 & -0.443626 & 0.828359 \\
\hline $\mathrm{C}$ & -2.596285 & 0.809571 & 1.115194 \\
\hline $\mathrm{H}$ & -3.113067 & 1.503786 & 1.776378 \\
\hline $\mathrm{C}$ & -1.331655 & 1.131212 & 0.656436 \\
\hline $\mathrm{C}$ & -0.640653 & 2.309139 & 1.078112 \\
\hline $\mathrm{H}$ & -1.191231 & 3.055699 & 1.648492 \\
\hline $\mathrm{C}$ & -0.669514 & 0.257044 & -0.402989 \\
\hline $\mathrm{C}$ & -0.967308 & 0.870318 & -1.839995 \\
\hline $\mathrm{H}$ & -0.529485 & 1.876258 & -1.852317 \\
\hline $\mathrm{H}$ & -0.401383 & 0.269977 & -2.562518 \\
\hline $\mathrm{C}$ & -2.429439 & 0.951756 & -2.293364 \\
\hline $\mathrm{H}$ & -3.037042 & 1.560166 & -1.615728 \\
\hline $\mathrm{H}$ & -2.891074 & -0.038387 & -2.365340 \\
\hline $\mathrm{C}$ & -1.169479 & -1.176804 & -0.324275 \\
\hline $\mathrm{C}$ & -0.389057 & -2.185773 & -0.946135 \\
\hline $\mathrm{H}$ & -0.845614 & -3.156665 & -1.133473 \\
\hline $\mathrm{C}$ & -2.473234 & -1.423347 & 0.153928 \\
\hline $\mathrm{H}$ & -2.888270 & -2.425149 & 0.052500 \\
\hline $\mathrm{C}$ & 3.641401 & 0.498452 & -0.412460 \\
\hline
\end{tabular}

\begin{tabular}{|l|l|l|l|}
\hline $\mathrm{C}$ & 3.010815 & -0.649009 & -0.888663 \\
\hline $\mathrm{H}$ & 3.598865 & -1.456803 & -1.319302 \\
\hline $\mathrm{C}$ & 1.609957 & -0.785013 & -0.816988 \\
\hline $\mathrm{C}$ & 0.944661 & -1.992804 & -1.227689 \\
\hline $\mathrm{H}$ & 1.529856 & -2.779209 & -1.698506 \\
\hline $\mathrm{C}$ & 0.838758 & 0.259728 & -0.232130 \\
\hline $\mathrm{C}$ & 0.233092 & -1.037096 & 2.106383 \\
\hline $\mathrm{H}$ & -0.826915 & -1.121991 & 2.315185 \\
\hline $\mathrm{H}$ & 0.690716 & -0.100527 & 2.404554 \\
\hline $\mathrm{C}$ & 1.062273 & -2.263834 & 2.061195 \\
\hline $\mathrm{H}$ & 0.536916 & -3.125429 & 2.494014 \\
\hline $\mathrm{H}$ & 1.312604 & -2.562983 & 1.020029 \\
\hline $\mathrm{C}$ & 1.490280 & 1.440426 & 0.236387 \\
\hline $\mathrm{C}$ & 0.697522 & 2.480089 & 0.843892 \\
\hline $\mathrm{H}$ & 1.204065 & 3.377181 & 1.193121 \\
\hline $\mathrm{C}$ & 2.889610 & 1.532013 & 0.152717 \\
\hline $\mathrm{H}$ & 3.386063 & 2.423959 & 0.529314 \\
\hline $\mathrm{H}$ & 2.023274 & -2.130148 & 2.573729 \\
\hline $\mathrm{H}$ & -2.477421 & 1.413850 & -3.287462 \\
\hline $\mathrm{H}$ & 4.722838 & 0.588947 & -0.476571 \\
\hline $\mathrm{H}$ & -4.179513 & -0.667185 & 1.216408 \\
\hline
\end{tabular}

\begin{tabular}{|l|l|}
\hline Electronic Energy & -774.094776 \\
\hline Sum of electronic and zero-point Energies & -773.758148 \\
\hline Sum of electronic and thermal Energies & -773.741339 \\
\hline Sum of electronic and thermal Enthalpies & -773.740394 \\
\hline Sum of electronic and thermal Free Energies & -773.800751 \\
\hline
\end{tabular}

Imaginary mode $=114 \mathrm{icm}^{-1}$ 
$3 b$

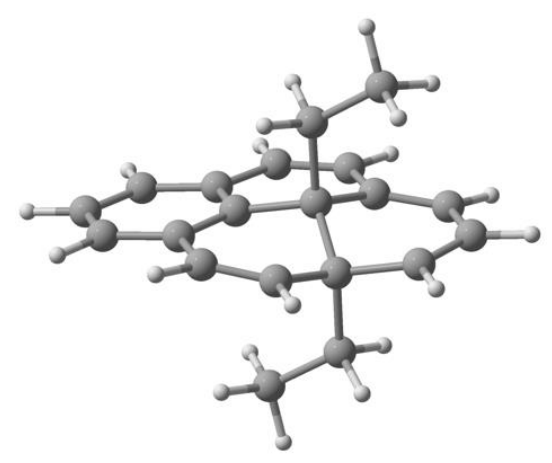

\begin{tabular}{|c|l|l|l|}
\hline \multicolumn{4}{|c}{ Cartesian Coordinates / } \\
\hline & \multicolumn{1}{|c|}{$\mathrm{x}$} & $\mathrm{y}$ & \multicolumn{1}{c|}{$\mathrm{z}$} \\
\hline $\mathrm{C}$ & 3.259391 & 0.099043 & -0.435576 \\
\hline $\mathrm{C}$ & 2.496801 & 1.292755 & -0.778403 \\
\hline $\mathrm{H}$ & 3.009126 & 2.127797 & -1.253871 \\
\hline $\mathrm{C}$ & 1.162166 & 1.373254 & -0.512245 \\
\hline $\mathrm{C}$ & 0.338490 & 2.511235 & -0.859440 \\
\hline $\mathrm{H}$ & 0.827359 & 3.386545 & -1.284111 \\
\hline $\mathrm{C}$ & 0.524741 & 0.241014 & 0.281877 \\
\hline $\mathrm{C}$ & 0.730844 & 0.582328 & 1.832642 \\
\hline $\mathrm{H}$ & 0.187501 & 1.524165 & 1.979722 \\
\hline $\mathrm{H}$ & 0.184409 & -0.174695 & 2.402207 \\
\hline $\mathrm{C}$ & 2.121602 & 0.740250 & 2.460490 \\
\hline $\mathrm{H}$ & 2.753187 & 1.449505 & 1.917080 \\
\hline $\mathrm{H}$ & 2.659800 & -0.209401 & 2.526925 \\
\hline $\mathrm{C}$ & 1.119593 & -1.127213 & -0.176688 \\
\hline $\mathrm{C}$ & 0.469417 & -2.229141 & 0.632060 \\
\hline $\mathrm{H}$ & 1.048339 & -3.124031 & 0.858294 \\
\hline $\mathrm{C}$ & 2.634514 & -1.044923 & -0.082912 \\
\hline $\mathrm{C}$ & -3.787020 & 0.127449 & 0.291494 \\
\hline $\mathrm{C}$ & -3.048728 & -0.993676 & 0.680341 \\
\hline
\end{tabular}

\begin{tabular}{|l|l|l|l|}
\hline $\mathrm{H}$ & -3.560181 & -1.891335 & 1.021732 \\
\hline $\mathrm{C}$ & -1.645650 & -0.977675 & 0.619587 \\
\hline $\mathrm{C}$ & -0.832015 & -2.151939 & 0.969380 \\
\hline $\mathrm{H}$ & -1.322079 & -2.977037 & 1.483683 \\
\hline $\mathrm{C}$ & -0.992649 & 0.190070 & 0.178214 \\
\hline $\mathrm{C}$ & 0.904107 & -1.472555 & -1.721000 \\
\hline $\mathrm{C}$ & -0.497024 & -1.698117 & -2.303454 \\
\hline $\mathrm{H}$ & -1.063248 & -2.455583 & -1.752652 \\
\hline $\mathrm{H}$ & -1.091985 & -0.780874 & -2.327720 \\
\hline $\mathrm{C}$ & -1.728221 & 1.320666 & -0.217561 \\
\hline $\mathrm{C}$ & -1.010842 & 2.495618 & -0.706560 \\
\hline $\mathrm{H}$ & -1.599903 & 3.364609 & -0.992622 \\
\hline $\mathrm{C}$ & -3.134466 & 1.274056 & -0.161981 \\
\hline $\mathrm{H}$ & -3.710612 & 2.143147 & -0.472864 \\
\hline $\mathrm{H}$ & 1.401133 & -0.683422 & -2.294742 \\
\hline $\mathrm{H}$ & 1.492149 & -2.385418 & -1.889724 \\
\hline $\mathrm{H}$ & 3.198671 & -1.950524 & 0.136524 \\
\hline $\mathrm{H}$ & -0.390754 & -2.052633 & -3.337105 \\
\hline $\mathrm{H}$ & 1.994022 & 1.126429 & 3.480630 \\
\hline $\mathrm{H}$ & -4.872791 & 0.104125 & 0.338069 \\
\hline $\mathrm{H}$ & 4.345551 & 0.143636 & -0.481054 \\
\hline
\end{tabular}

\begin{tabular}{|l|l|}
\hline Electronic Energy & -774.146885 \\
\hline Sum of electronic and zero-point Energies & -773.805015 \\
\hline Sum of electronic and thermal Energies & -773.788972 \\
\hline Sum of electronic and thermal Enthalpies & -773.788028 \\
\hline Sum of electronic and thermal Free Energies & -773.846046 \\
\hline
\end{tabular}

Imaginary mode $=114 \mathrm{icm}^{-1}$ 


\section{$3 b-4 b$ TS}

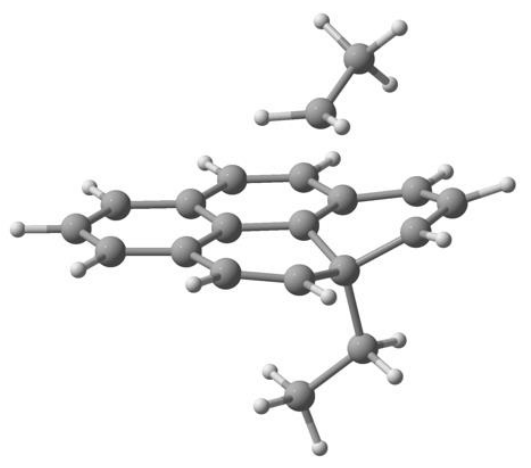

\begin{tabular}{|c|c|c|c|}
\hline \multicolumn{4}{|c|}{ Cartesian Coordinates / } \\
\hline & \multicolumn{1}{|c|}{$\mathrm{X}$} & $\mathrm{y}$ & $\mathrm{Z}$ \\
\hline $\mathrm{C}$ & -3.179793 & -0.181018 & -0.191230 \\
\hline $\mathrm{C}$ & -2.454999 & -1.155206 & -0.922231 \\
\hline $\mathrm{H}$ & -2.976584 & -1.956982 & -1.439111 \\
\hline $\mathrm{C}$ & -1.048906 & -1.144356 & -0.885550 \\
\hline $\mathrm{C}$ & -0.259345 & -2.228484 & -1.412041 \\
\hline $\mathrm{H}$ & -0.772166 & -3.029526 & -1.940801 \\
\hline $\mathrm{C}$ & -0.384995 & -0.091808 & -0.183792 \\
\hline $\mathrm{C}$ & -1.093590 & -0.754707 & 2.183928 \\
\hline $\mathrm{H}$ & -0.012677 & -0.787023 & 2.233599 \\
\hline $\mathrm{H}$ & -1.539554 & 0.073988 & 2.721122 \\
\hline $\mathrm{C}$ & -1.844786 & -2.023276 & 2.086889 \\
\hline $\mathrm{H}$ & -1.202563 & -2.895275 & 2.262399 \\
\hline $\mathrm{H}$ & -2.278183 & -2.168738 & 1.069238 \\
\hline $\mathrm{C}$ & -1.120553 & 1.224236 & -0.009113 \\
\hline $\mathrm{C}$ & -0.412578 & 2.102889 & 0.995163 \\
\hline $\mathrm{H}$ & -0.988612 & 2.918372 & 1.432601 \\
\hline $\mathrm{C}$ & -2.532126 & 0.870271 & 0.408007 \\
\hline $\mathrm{H}$ & -3.090356 & 1.593707 & 1.001274 \\
\hline $\mathrm{C}$ & 3.827678 & -0.245349 & 0.363376 \\
\hline
\end{tabular}

\begin{tabular}{|l|l|l|l|}
\hline $\mathrm{C}$ & 3.086176 & 0.823341 & 0.893910 \\
\hline $\mathrm{H}$ & 3.590611 & 1.604333 & 1.459089 \\
\hline $\mathrm{C}$ & 1.705055 & 0.896949 & 0.706665 \\
\hline $\mathrm{C}$ & 0.895832 & 1.970389 & 1.277864 \\
\hline $\mathrm{H}$ & 1.385568 & 2.665071 & 1.958615 \\
\hline $\mathrm{C}$ & 1.043653 & -0.131599 & -0.027645 \\
\hline $\mathrm{C}$ & -1.231423 & 2.030792 & -1.371764 \\
\hline $\mathrm{H}$ & -1.824172 & 2.932006 & -1.156923 \\
\hline $\mathrm{H}$ & -1.828816 & 1.421568 & -2.059558 \\
\hline $\mathrm{C}$ & 0.079454 & 2.432671 & -2.056280 \\
\hline $\mathrm{H}$ & 0.711024 & 3.048648 & -1.407480 \\
\hline $\mathrm{H}$ & 0.661756 & 1.556192 & -2.360264 \\
\hline $\mathrm{C}$ & 1.792537 & -1.228268 & -0.540098 \\
\hline $\mathrm{C}$ & 1.094259 & -2.266702 & -1.253429 \\
\hline $\mathrm{H}$ & 1.671852 & -3.093967 & -1.660454 \\
\hline $\mathrm{C}$ & 3.190376 & -1.258690 & -0.340684 \\
\hline $\mathrm{H}$ & 3.763695 & -2.092679 & -0.739963 \\
\hline $\mathrm{H}$ & -0.139072 & 3.014998 & -2.960169 \\
\hline $\mathrm{H}$ & -2.699815 & -2.051884 & 2.775057 \\
\hline $\mathrm{H}$ & 4.903614 & -0.281941 & 0.513623 \\
\hline $\mathrm{H}$ & -4.247118 & -0.323314 & -0.033580 \\
\hline
\end{tabular}

\begin{tabular}{|l|l|}
\hline Electronic Energy & -774.101577 \\
\hline Sum of electronic and zero-point Energies & -773.764538 \\
\hline Sum of electronic and thermal Energies & -773.747866 \\
\hline Sum of electronic and thermal Enthalpies & -773.746922 \\
\hline Sum of electronic and thermal Free Energies & -773.806989 \\
\hline
\end{tabular}

Imaginary mode $=262 \mathrm{i} \mathrm{cm}^{-1}$ 


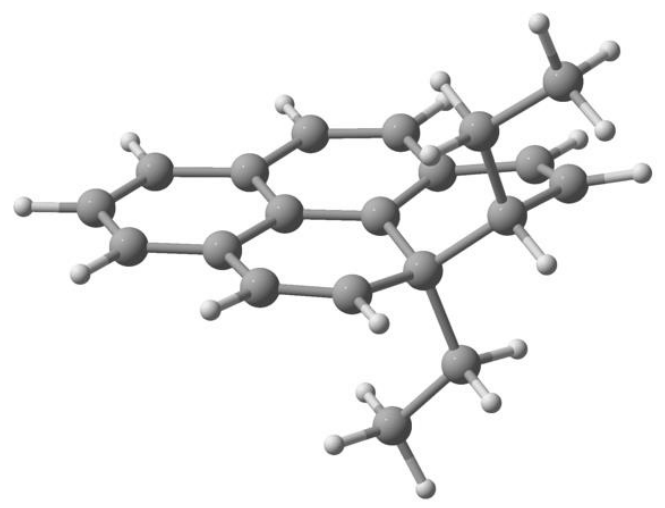

\begin{tabular}{|c|l|l|l|}
\hline \multicolumn{4}{|c|}{ Cartesian Coordinates / } \\
\hline & \multicolumn{1}{|c|}{$\mathrm{X}$} & \multicolumn{1}{|c|}{$\mathrm{y}$} & \multicolumn{1}{c|}{$\mathrm{z}$} \\
\hline $\mathrm{C}$ & -2.788676 & 1.091008 & 0.352844 \\
\hline $\mathrm{C}$ & -1.837427 & 2.024315 & 0.530331 \\
\hline $\mathrm{H}$ & -2.105040 & 3.052413 & 0.768958 \\
\hline $\mathrm{C}$ & -0.418039 & 1.711727 & 0.333157 \\
\hline $\mathrm{C}$ & 0.547293 & 2.745252 & 0.203069 \\
\hline $\mathrm{H}$ & 0.229101 & 3.779041 & 0.322103 \\
\hline $\mathrm{C}$ & -0.023914 & 0.377012 & 0.208833 \\
\hline $\mathrm{C}$ & -2.561471 & -0.502760 & -1.584271 \\
\hline $\mathrm{H}$ & -1.849033 & 0.172769 & -2.075321 \\
\hline $\mathrm{H}$ & -2.256062 & -1.521884 & -1.851401 \\
\hline $\mathrm{C}$ & -3.973803 & -0.246195 & -2.125618 \\
\hline $\mathrm{H}$ & -4.291277 & 0.790233 & -1.963291 \\
\hline $\mathrm{H}$ & -4.711155 & -0.902985 & -1.644508 \\
\hline $\mathrm{C}$ & -1.037075 & -0.721327 & 0.527289 \\
\hline $\mathrm{C}$ & -0.583391 & -2.065803 & 0.011067 \\
\hline $\mathrm{H}$ & -1.318136 & -2.870209 & 0.040791 \\
\hline $\mathrm{C}$ & -2.440767 & -0.330403 & -0.045438 \\
\hline $\mathrm{H}$ & -3.171251 & -1.013419 & 0.415439 \\
\hline $\mathrm{C}$ & 3.976032 & -0.528891 & -0.877533 \\
\hline
\end{tabular}

\begin{tabular}{|l|l|l|l|}
\hline $\mathrm{C}$ & 3.012056 & -1.561702 & -0.786384 \\
\hline $\mathrm{H}$ & 3.301794 & -2.587120 & -1.006486 \\
\hline $\mathrm{C}$ & 1.701487 & -1.286330 & -0.431572 \\
\hline $\mathrm{C}$ & 0.675167 & -2.324566 & -0.380358 \\
\hline $\mathrm{H}$ & 0.961499 & -3.330354 & -0.683981 \\
\hline $\mathrm{C}$ & 1.313809 & 0.068101 & -0.152820 \\
\hline $\mathrm{C}$ & -1.185820 & -0.859602 & 2.094265 \\
\hline $\mathrm{H}$ & -1.914555 & -1.663396 & 2.275418 \\
\hline $\mathrm{H}$ & -1.635780 & 0.062360 & 2.477494 \\
\hline $\mathrm{C}$ & 0.095952 & -1.155247 & 2.879514 \\
\hline $\mathrm{H}$ & 0.578223 & -2.079705 & 2.544229 \\
\hline $\mathrm{H}$ & 0.824193 & -0.342022 & 2.789111 \\
\hline $\mathrm{H}$ & -0.141132 & -1.269099 & 3.944439 \\
\hline $\mathrm{C}$ & 2.280198 & 1.116388 & -0.290116 \\
\hline $\mathrm{C}$ & 1.863875 & 2.457606 & -0.081344 \\
\hline $\mathrm{H}$ & 2.595317 & 3.257807 & -0.170520 \\
\hline $\mathrm{C}$ & 3.618734 & 0.781144 & -0.641002 \\
\hline $\mathrm{H}$ & 4.353266 & 1.578593 & -0.729506 \\
\hline $\mathrm{H}$ & -4.015546 & -0.437491 & -3.204443 \\
\hline $\mathrm{H}$ & 4.999229 & -0.774755 & -1.150132 \\
\hline $\mathrm{H}$ & -3.838973 & 1.360871 & 0.438129 \\
\hline
\end{tabular}

\begin{tabular}{|l|l|}
\hline Electronic Energy & -774.201305 \\
\hline Sum of electronic and zero-point Energies & -773.858849 \\
\hline Sum of electronic and thermal Energies & -773.842451 \\
\hline Sum of electronic and thermal Enthalpies & -773.841507 \\
\hline Sum of electronic and thermal Free Energies & -773.901372 \\
\hline
\end{tabular}


$5 b$

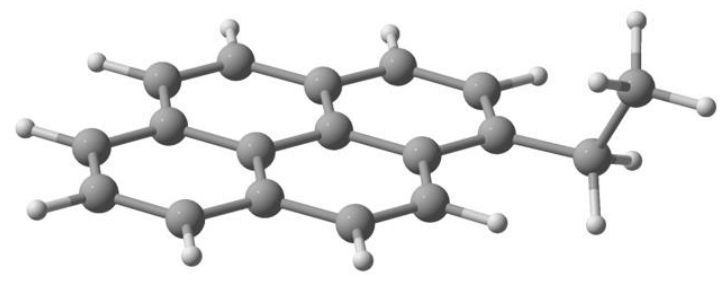

\begin{tabular}{|l|l|l|l|}
\hline \multicolumn{4}{|c|}{ Cartesian Coordinates / } \\
\hline & \multicolumn{1}{|c|}{$\mathrm{X}$} & $\mathrm{y}$ & \multicolumn{1}{c|}{$\mathrm{z}$} \\
\hline $\mathrm{C}$ & 2.613638 & 1.542925 & -0.227342 \\
\hline $\mathrm{C}$ & 1.510432 & 2.383065 & -0.101296 \\
\hline $\mathrm{C}$ & 0.212866 & 1.854401 & -0.029544 \\
\hline $\mathrm{C}$ & -0.949373 & 2.691482 & 0.097539 \\
\hline H & -0.805979 & 3.769002 & 0.141265 \\
\hline $\mathrm{C}$ & 0.045677 & 0.436278 & -0.088558 \\
\hline $\mathrm{C}$ & 4.221478 & -1.247984 & 0.973850 \\
\hline $\mathrm{H}$ & 4.444338 & -0.428742 & 1.667258 \\
\hline $\mathrm{C}$ & 1.188627 & -0.419699 & -0.214315 \\
\hline $\mathrm{C}$ & 0.957522 & -1.841122 & -0.270479 \\
\hline $\mathrm{H}$ & 1.806032 & -2.510698 & -0.365318 \\
\hline $\mathrm{C}$ & 2.486214 & 0.148718 & -0.283007 \\
\hline $\mathrm{C}$ & -3.864398 & -1.216624 & 0.108991 \\
\hline $\mathrm{C}$ & -2.760581 & -2.060414 & -0.013560 \\
\hline $\mathrm{C}$ & -1.458643 & -1.534059 & -0.080323 \\
\hline
\end{tabular}

\begin{tabular}{|l|l|l|l|}
\hline $\mathrm{C}$ & -0.297988 & -2.369675 & -0.207942 \\
\hline $\mathrm{H}$ & -0.438786 & -3.447468 & -0.254566 \\
\hline $\mathrm{C}$ & -1.271003 & -0.119051 & -0.021930 \\
\hline $\mathrm{C}$ & -2.409759 & 0.737912 & 0.104052 \\
\hline $\mathrm{C}$ & -2.202276 & 2.159820 & 0.161626 \\
\hline $\mathrm{H}$ & -3.071490 & 2.806738 & 0.257688 \\
\hline $\mathrm{C}$ & -3.692688 & 0.166993 & 0.167549 \\
\hline $\mathrm{H}$ & -4.557661 & 0.819565 & 0.263561 \\
\hline $\mathrm{C}$ & 3.738832 & -0.699968 & -0.384055 \\
\hline $\mathrm{H}$ & 4.538670 & -0.089493 & -0.821386 \\
\hline $\mathrm{H}$ & 3.584890 & -1.534414 & -1.079424 \\
\hline $\mathrm{H}$ & 3.461465 & -1.881846 & 1.444265 \\
\hline $\mathrm{H}$ & 5.133075 & -1.845094 & 0.848320 \\
\hline $\mathrm{H}$ & 1.649741 & 3.461297 & -0.062647 \\
\hline $\mathrm{H}$ & -2.899291 & -3.138348 & -0.058750 \\
\hline $\mathrm{H}$ & 3.608247 & 1.980558 & -0.287196 \\
\hline $\mathrm{H}$ & -4.864720 & -1.639054 & 0.159394 \\
\hline \multicolumn{3}{|c}{}
\end{tabular}

\begin{tabular}{|l|l|}
\hline Electronic Energy & -694.422156 \\
\hline Sum of electronic and zero-point Energies & -694.158307 \\
\hline Sum of electronic and thermal Energies & -694.145296 \\
\hline Sum of electronic and thermal Enthalpies & -694.144352 \\
\hline Sum of electronic and thermal Free Energies & -694.197278 \\
\hline
\end{tabular}




\section{Pyrene}

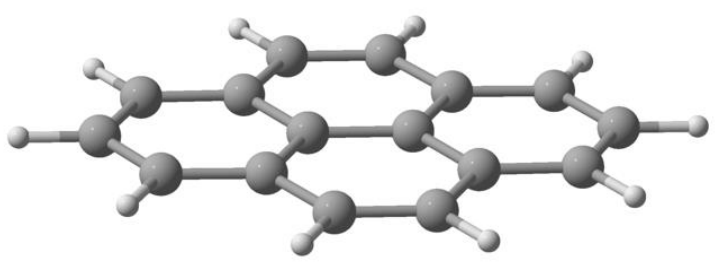

\begin{tabular}{|c|c|c|c|}
\hline \multicolumn{4}{|c|}{ Cartesian Coordinates / $\AA$} \\
\hline & $\mathrm{X}$ & $\mathrm{y}$ & $\mathrm{z}$ \\
\hline $\mathrm{C}$ & 0.000000 & 0.000000 & -3.527743 \\
\hline $\mathrm{C}$ & 0.000000 & -1.211873 & -2.835664 \\
\hline $\mathrm{C}$ & 0.000000 & -1.236959 & -1.430315 \\
\hline $\mathrm{C}$ & 0.000000 & -2.465707 & -0.681694 \\
\hline $\mathrm{H}$ & 0.000000 & -3.404949 & -1.230492 \\
\hline $\mathrm{C}$ & 0.000000 & 0.000000 & -0.713975 \\
\hline $\mathrm{C}$ & 0.000000 & 1.236959 & -1.430315 \\
\hline $\mathrm{C}$ & 0.000000 & 2.465707 & -0.681694 \\
\hline $\mathrm{H}$ & 0.000000 & 3.404949 & -1.230492 \\
\hline $\mathrm{C}$ & 0.000000 & 1.211873 & -2.835664 \\
\hline $\mathrm{C}$ & 0.000000 & 0.000000 & 3.527743 \\
\hline $\mathrm{C}$ & 0.000000 & 1.211873 & 2.835664 \\
\hline $\mathrm{C}$ & 0.000000 & 1.236959 & 1.430315 \\
\hline
\end{tabular}

\begin{tabular}{|l|l|l|l|}
\hline $\mathrm{C}$ & 0.000000 & 2.465707 & 0.681694 \\
\hline $\mathrm{H}$ & 0.000000 & 3.404949 & 1.230492 \\
\hline $\mathrm{C}$ & 0.000000 & 0.000000 & 0.713975 \\
\hline $\mathrm{C}$ & 0.000000 & -1.236959 & 1.430315 \\
\hline $\mathrm{C}$ & 0.000000 & -2.465707 & 0.681694 \\
\hline $\mathrm{H}$ & 0.000000 & -3.404949 & 1.230492 \\
\hline $\mathrm{C}$ & 0.000000 & -1.211873 & 2.835664 \\
\hline $\mathrm{H}$ & 0.000000 & -2.151805 & 3.383156 \\
\hline $\mathrm{H}$ & 0.000000 & 2.151805 & -3.383156 \\
\hline $\mathrm{H}$ & 0.000000 & -2.151805 & -3.383156 \\
\hline $\mathrm{H}$ & 0.000000 & 2.151805 & 3.383156 \\
\hline $\mathrm{H}$ & 0.000000 & 0.000000 & -4.614749 \\
\hline $\mathrm{H}$ & 0.000000 & 0.000000 & 4.614749 \\
\hline
\end{tabular}

\begin{tabular}{|l|l|}
\hline Electronic Energy & -615.79213 \\
\hline Sum of electronic and zero-point Energies & -615.584927 \\
\hline Sum of electronic and thermal Energies & -615.574875 \\
\hline Sum of electronic and thermal Enthalpies & -615.573931 \\
\hline Sum of electronic and thermal Free Energies & -615.618913 \\
\hline
\end{tabular}


Table S5. Reaction energetics for the transformation of DHP $\mathbf{1 b}$ to pyrene.

\begin{tabular}{|c|c|c|c|c|c|c|c|}
\hline & Energy & $1 b \rightarrow 3 b$ & $\begin{array}{c}1 b \rightarrow 3 b \\
\text { Barrier }\end{array}$ & $3 b \rightarrow 4 b$ & $\begin{array}{c}3 b \rightarrow 4 b \\
\text { Barrier }\end{array}$ & $\begin{array}{c}4 b \rightarrow 5 b+ \\
\text { ethane }\end{array}$ & $\begin{array}{c}4 b \rightarrow \text { Pyrene } \\
+ \text { butane }\end{array}$ \\
\hline \multirow{5}{*}{ 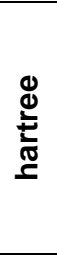 } & $\Delta \mathbf{E}$ & 0.000281 & 0.052390 & -0.054421 & 0.045308 & -0.051269 & -0.048868 \\
\hline & $\Delta($ E+fzpe $)$ & 0.001084 & 0.047951 & -0.053834 & 0.040477 & -0.054634 & -0.051323 \\
\hline & $\Delta(E+$ thermal $)$ & 0.000922 & 0.048555 & -0.053479 & 0.041106 & -0.054553 & -0.051903 \\
\hline & $\Delta \mathbf{H}$ & 0.000922 & 0.048556 & -0.053479 & 0.041106 & -0.053609 & -0.050959 \\
\hline & $\Delta \mathbf{G}$ & 0.000603 & 0.045898 & -0.055326 & 0.039057 & -0.072500 & -0.070150 \\
\hline \multirow{5}{*}{$\begin{array}{l}\bar{o} \\
\stackrel{\rho}{\mathbf{p}}\end{array}$} & $\Delta \mathrm{E}$ & 0.7 & 137.5 & -142.9 & 119.0 & -134.6 & -128.3 \\
\hline & $\Delta($ E+zpe $)$ & 2.8 & 125.9 & -141.3 & 106.3 & -143.4 & -134.7 \\
\hline & $\Delta(E+$ thermal $)$ & 2.4 & 127.5 & -140.4 & 107.9 & -143.2 & -136.3 \\
\hline & $\Delta \mathbf{H}$ & 2.4 & 127.5 & -140.4 & 107.9 & -140.8 & -133.8 \\
\hline & $\Delta \mathbf{G}$ & 1.6 & 120.5 & -145.3 & 102.5 & -190.3 & -184.2 \\
\hline \multirow{5}{*}{ 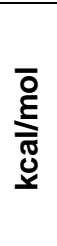 } & $\Delta E$ & 0.2 & 32.9 & -34.1 & 28.4 & -32.2 & -30.7 \\
\hline & $\Delta(E+z p e)$ & 0.7 & 30.1 & -33.8 & 25.4 & -34.3 & -32.2 \\
\hline & $\Delta(E+$ thermal $)$ & 0.6 & 30.5 & -33.6 & 25.8 & -34.2 & -32.6 \\
\hline & $\Delta \mathbf{H}$ & 0.6 & 30.5 & -33.6 & 25.8 & -33.6 & -32.0 \\
\hline & $\Delta \mathbf{G}$ & 0.4 & 28.8 & -34.7 & 24.5 & -45.5 & -44.0 \\
\hline
\end{tabular}




\section{References}

1. Roemer, M.; Gillespie, A.; Jago, D.; Milan, D. C.; Alqahtani, J.; Sangtarash, S.; Sadeghi, H.; Spackman, P.; Sobolev, A. N.; Skelton, B. W.; Grosjean, A.; Walkey, M. C.; Kampman, S.; Vezzoli, A.; Simpson, P.; Massi, M.; Planje, I.; Higgins, S.; Lambert, C.; Piggott, M. J.; Nichols, R.; Koutsantonis, G. A., Syntheses and Charge Transport through 2,7- and 4,9-Dialkynyldihydropyrene Molecular Switches. Submitted 2021.

2. CrysAlis PRO 1.171.41.103a. Rigaku OD: 2021.

3. Sheldrick, SHELXT 2014/5 2014.

4. Sheldrick, SHELXT 2018/2 2018.

5. Sheldrick, XL. 2018/3 ed.; 2008.

6. CrysAlis PRO 1.171.40.53. Rigaku OD: 2019.

7. Dolomanov, O. V.; Bourhis, L. J.; Gildea, R. J.; Howard, J. A. K.; Puschmann, H., OLEX2: A Complete Structure Solution, Refinement and Analysis Program. J. Appl. Cryst. 2009, 42 (2), 339-341.

8. Frisch, M. J.; Trucks, G. W.; Schlegel, H. B.; Scuseria, G. E.; Robb, M. A.; Cheeseman, J. R.; Scalmani, G.; Barone, V.; Mennucci, B.; Petersson, G. A.; Nakatsuji, H.; Caricato, M.; Li, X.; Hratchian, H. P.; Izmaylov, A. F.; Bloino, J.; Zheng, G.; Sonnenberg, J. L.; Hada, M.; Ehara, M.; Toyota, K.; Fukuda, R.; Hasegawa, J.; Ishida, M.; Nakajima, T.; Honda, Y.; Kitao, O.; Nakai, H.; Vreven, T.; Jr., J. A. M.; Peralta, J. E.; Ogliaro, F.; Bearpark, M.; Heyd, J. J.; Brothers, E.; Kudin, K. N.; Staroverov, V. N.; Keith, T.; Kobayashi, R.; Normand, J.; Raghavachari, K.; Rendell, A.; Burant, J. C.; lyengar, S. S.; Tomasi, J.; Cossi, M.; Rega, N.; Millam, J. M.; Klene, M.; Knox, J. E.; Cross, J. B.; Bakken, V.; Adamo, C.; Jaramillo, J.; Gomperts, R.; Stratmann, R. E.; Yazyev, O.; Austin, A. J.; Cammi, 
R.; Pomelli, C.; Ochterski, J. W.; Martin, R. L.; Morokuma, K.; Zakrzewski, V. G.; Voth, G. A.; Salvador, P.; Dannenberg, J. J.; Dapprich, S.; Daniels, A. D.; Farkas, O.; Foresman, J. B.; Ortiz, J. V.; Cioslowski, J.; Fox, D. J. Gaussian 09, , Gaussian, Inc.: Wallingford CT, 2009.

9. Becke, A. D., Density-functional thermochemistry. III. The role of exact exchange. J. Chem. Phys. 1993, 98 (7), 5648-5652.

10. Lee, C.; Yang, W.; Parr, R. G., Development of the Colle-Salvetti correlationenergy formula into a functional of the electron density. Phys. Rev. B 1988, 37 (2), 785-789.

11. Ditchfield, R.; Hehre, W. J.; Pople, J. A., Self-Consistent Molecular-Orbital Methods. IX. An Extended Gaussian-Type Basis for Molecular-Orbital Studies of Organic Molecules. J. Chem. Phys. 1971, 54, 724-728.

12. Hehre, W. J.; Ditchfield, R.; Pople, J. A., Self-Consistent Molecular Orbital Methods. XII. Further Extensions of Gaussian-Type Basis Sets for Use in Molecular Orbital Studies of Organic Molecules. J. Chem. Phys. 1972, 56, 2257-2261.

13. Hariharan, P. C.; Pople, J. A., The influence of polarization functions on molecular orbital hydrogenation energies. Theor. Chim. Acta 1973, 28, 213-222.

14. Francl, M. M.; Pietro, W. J.; Hehre, W. J.; Binkley, J. S.; Gordon, M. S.; DeFrees, D. J.; Pople, J. A., Self-consistent molecular orbital methods. XXIII. A polarization-type basis set for second-row elements. J. Chem. Phys. 1982, 77, 36543665.

15. Clark, T.; Chandrasekhar, J.; Spitznagel, G. W.; Schleyer, P. V. R., Efficient diffuse function-augmented basis sets for anion calculations. III. The $3-21+G$ basis set for first-row elements, Li-F. J. Comput. Chem. 1983, 4, 294-301. 
16. Spitznagel, G. W.; Clark, T.; Schleyer, P. v. R.; Hehre, W. J., An evaluation of the performance of diffuse function-augmented basis sets for second row elements, Na-Cl. J. Comput. Chem. 1987, 8, 1109-1116.

17. CYLview20; Legault, C. Y., Université de Sherbrooke, 2020 (http://www.cylview.org). 